\title{
The Corneal Endothelium
}

\author{
S. J. TUFT and D. J. COSTER \\ London and Adelaide
}

\begin{abstract}
Summary
The endothelium is a monolayer of cells on the posterior corneal surface that transports water from the stroma into the anterior chamber. This movement of water counters a natural tendency for the stroma to swell and is necessary to maintain a transparent cornea. Embryologic studies, in particular the demonstration of the derivation of the endothelium from the neural crest, have provided insight into the factors that govern the response of this tissue to disease. In some species the endothelium can regenerate after injury, but in man cellular enlargement is the main mechanism of repair after cell loss. A clinical estimate of endothelial cell density and function is provided by specular microscopy, fluorophotometry and pachymetry. In this paper we review the development, structure and function of the corneal endothelium, and then consider the pathological processes that can affect this tissue.
\end{abstract}

There have been considerable advances towards an understanding of the physiology of the endothelium since its role in maintaining corneal clarity was first recognised. Clinical interest has been spurred by the refinement of complex intraocular surgical techniques, appreciation of the susceptability of the endothelium to surgical trauma and the development of in vivo methods of evaluation that can demonstrate the dramatic changes in morphology which follow seemingly minor injuries. In addition, a reassessment of the embryogenesis of the corneal endothelium has influenced our interpretation of endothelial pathology. We are at a point where the current understanding of the development, structure and function of the corneal endothelium is providing an appreciation of the surprisingly diverse pathology which can affect this apparently simply monolayer of cells.

\section{The Normal Endothelium}

\section{Embryology}

The eye and periocular structures are formed from cells that are derived from four distinct embryologic tissues-surface ectoderm, mesoderm, neural tube and the neural crest (Fig. 1). ${ }^{1}$ Many of the structural roles of mesoderm in the rest of the body are assumed by

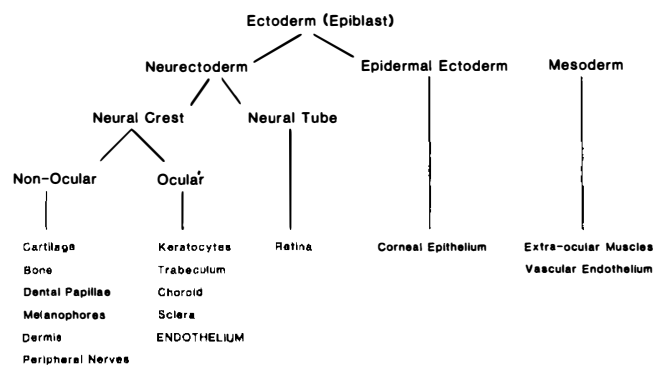

Fig. 1. A diagramatic representation of the derivation of ocular tissues from embryonic precursors. The corneal endothelium is a product of the neural crest.

From Department of Clinical Ophthalmology, Moorfields Eye Hospital, City Road, London, and Department of Ophthalmology, Flinders Medical Centre, Bedford Park, South Australia.

Correspondence to: Professor D. J. Coster, Department of Ophthalmology, Flinders Medical Centre, Bedford Park, South Australia 5042. 
the neural crest in the head and neck, and the neural crest has a crucial role in the development of the eye. . $3.4 .5^{-}$

The fundamental studies of ocular embryology have been performed in birds, with movement of the neural crest being mapped by transplanting labelled cells between embryos and following their development in the resulting chimera. ${ }^{6}$ Radioactively labelled cells can be identified for a few cell divisions during early oculogenesis, ${ }^{7}$ but, by using quail cells that contain an intrinsic nuclear marker which can be identified after transplantation into chick embryos, it has been possible to follow subsequent stages. ${ }^{8}$ This type of experiment has demonstrated the remarkable mobility of neural crest cells in the embryo and has shown that it is a population of these cells that ultimately forms the corneal endothelium.

Neural crest cells can first be identified as they separate from the neural plate, a thickening of the dorsal surface ectoderm. Prior to the closure of the neural folds at the anterior neuropore, the neural crest cells begin to move peripherally as primary mesenchyme (Fig. 2). In the primate, part of the migrating wave of neural crest cells comes to lie in a loose matrix at the rim of the optic cup and, at 40 days post-ovulation, these cells stream centrally through the loose fibrillar material of the primary cornea that has formed in the cleft between the lens vesicle and the surface ectoderm. ${ }^{9,10,11,12}$ This centripetal movement of neural crest cells is termed the first wave of mesenchymal migration; a second wave later contributes cells that form the keratocytes and stromal cells of the iris. ${ }^{13}$ Macrophages precede the migration of crest cells, which move over a layer of fibronectin into the primary corneal stroma to form a loosely arranged sheet of overlapping cells. ${ }^{14}$ This layer thins to a monolayer of endothelium by the eighth week of human gestation. Developmentally, it is not a true endothelium and should more correctly be called the posterior cell layer of the cornea or the posterior epithelium ${ }^{15}$ because its derivation is quite distinct from that of vascular endothelium. Cells of a similar origin cover the anterior surface of the iris and those in the anterior chamber angle migrate peripherally to form the lining of the trabecular meshwork. ${ }^{16,17}$
The inducers that mediate these complex cellular interactions have not been identified but it appears that the histogenesis of each migrating cell is in part determined by its locus of origin on the neural crest, with later modification by glycoproteins in the environment through which it moves. ${ }^{18,19,20}$ Needless to say, such a complex pattern may be modifed at several levels. The eventual formation of a monolayer appears to be determined by contact inhibition, with the lens and the primary cornea acting as substrata. ${ }^{21,22}$ Experiments show that the cells can move over any surface made available to them, to the extent that an intact junction between the lens equator and the optic cup is required to prevent backward migration of endothelial cells over the neuroretina. ${ }^{23}$ Removal of the lens vesicle results in a loss of maturation control with persistent multilayering of the endothelial cells on the posterior corneal surface. ${ }^{24}$

Intercellular junctions begin to form when the endothelial monolayer is complete. Gap junctions develop first, the apical band is in place by the sixteenth week of gestation and an adult configuration is achieved by twenty weeks. ${ }^{25}$ The formation of intercellular junctions corresponds with the beginning of aqueous secretion and the maturation of the barrier and transport functions of the corneal endothelium. In the avian model, the gradual increase in corneal transparency during the second half of gestation is dependent upon normal thyroid function. ${ }^{26,27}$ Thyroid hormones may control the deposition of ground substance, and thus the ability of the stroma to bind water, or they may regulate the maturation of the endothelial pump function.

Beginning at the eighth week of gestation, endothelial cells deposit Descemet's membrane. ${ }^{28}$ This first appears as patches of lamellar material and forms a complete layer by sixteen weeks. Collagen is continuously deposited thereafter until the eighth month of gestation, by which time the membrane forms a layer approximately $3 \mu \mathrm{m}$ thick. The collagen of Descemet's membrane formed in utero has a banded appearance by electron microscopy, with a microperiodicity of $110 \mu \mathrm{m} .{ }^{29}$ In contrast, Descemet's membrane that is secreted subsequently is finely granular and consists largely of non-banded basement 


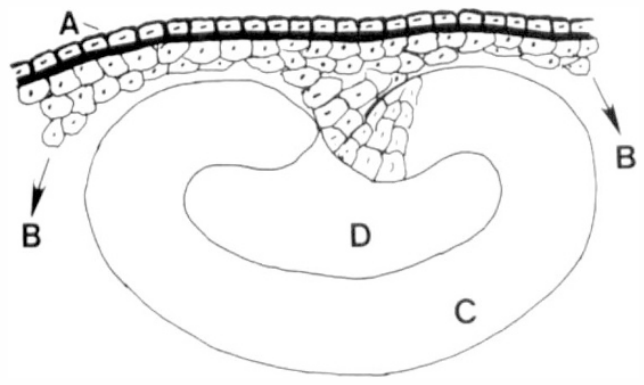

Fig. 2a.

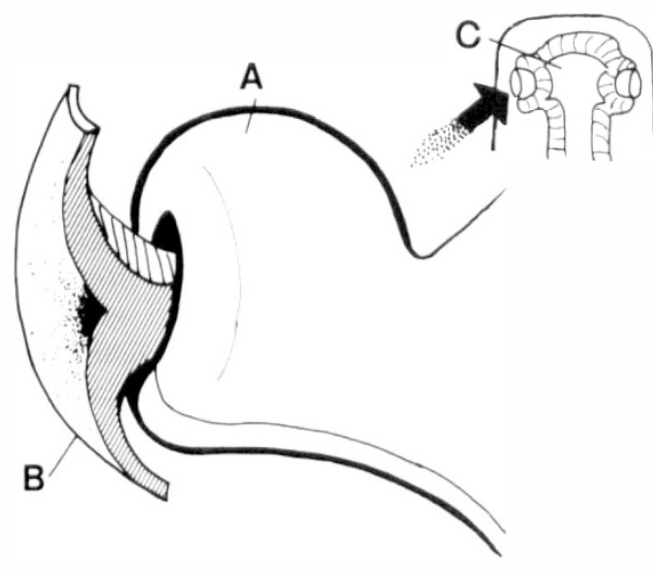

Fig. 2b.

membrane. The granular portion of the membrane accumulates throughout life and may reach a thickness of between 10 and $40 \mu \mathrm{m}$. There is, however, a wide variation in the rate at which Descemet's membrane is deposited, and a measurement of its thickness does not provide an accurate gauge as to a patients age. ${ }^{30}$

\section{Morphology}

At birth, the human endothelium comprises a monolayer of up to 500,000 cells, with a density as high as 7,500 cells $/ \mathrm{mm}^{2}$. During life, cell density progressively reduces (Fig. 3). ${ }^{31,32,33}$ An initial rapid decline occurs in the first year, reflecting hypertrophy of a fixed population of endothelial cells in response to continued corneal growth. ${ }^{34,35,36}$ Cell density continues to fall at a reduced rate until the mid-twenties due to endothelial cell loss, and there follows a more gradual decline

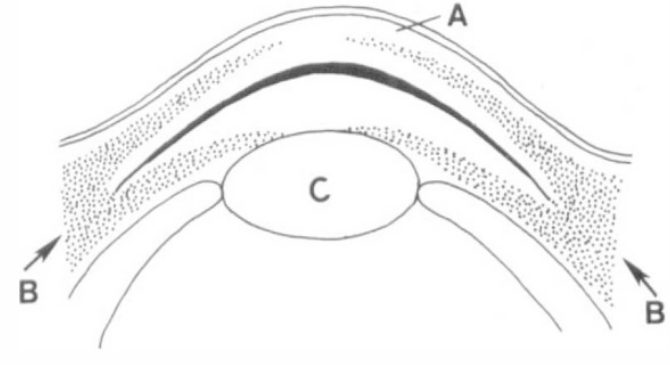

Fig. 2c.

Fig. 2. (a) Diagramatic representation of the migration of neural crest cells from a position dorsal to the neural tube to the posterior surface of the cornea, showing ectoderm $(A)$, neural crest cells $(B)$, neural ectoderm (C) and neural tube (D). (b) Outpouchings of the neuralectoderm at the level of the diencephalon form the optic vesicles which grow toward the surface ectoderm and induce the surface cells to elongate and form the lens placode. The diagram shows the optic vesicle $(A)$, surface ectoderm $(B)$ and diencephalon $(C)$. $B y$ a complex process of differential growth, the optic vesicles then invaginate to form the optic cups. The lens placode also invaginates and separates from the surface ectoderm to form the lens vesicle lying within the rim of the optic cup. The inner and outer cellular layers of the optic vesicles form the neuroretina and the retinal pigment epithelium respectively, and extend forward with the advancing rim of the optic cup to form elements of the iris. The epithelium of the cornea develops (following lens invagination) from surface ectoderm. (c) Crest cells move from a position between the surface ectoderm and the neural tube to lie at the tip of the optic cup. They migrate over the posterior surface of the cornea to form the corneal endothelium. The diagram shows the cornea $(A)$, neural crest cells $(B)$ and the lens (C).

into old age. ${ }^{37,38,39}$ It has been estimated that between the ages of 20 and 80 years the reduction in cell density averages $0.52 \%$ per year. ${ }^{40}$ As the mean age of a population sample increases, there is a spread in the range of their endothelial cell density counts,${ }^{31}$ so that the measurement of cell density is not a reliable index of the chronological age of a cornea. Longitudinal data on the change of cell density with age for individual corneas are not yet available. Concurrent with an observed reduction in cell numbers, the mean cell area of the surviving cells increases ${ }^{33,41}$ and there is an increased variation of cell size. These changes in cell density and shape with age have been observed to occur in the monkey, ${ }^{42}$ rat, ${ }^{43}$ cat,${ }^{44}$ dog $^{45}$ and rabbit, ${ }^{46}$ but in each of these species the adult mean cell 


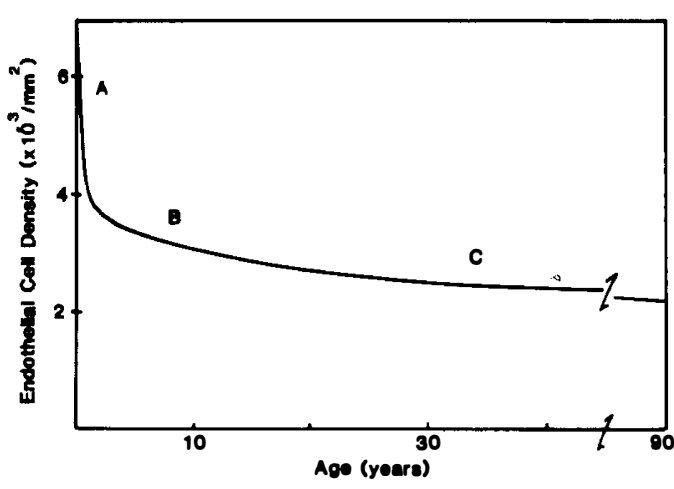

Fig. 3. Graphical representation of the fall in endothelial cell density that occurs with age. An initial very rapid decline in infancy $(A)$ levels off in the teens (B) to be followed by a gradual decline into old age (C). Details of the fall in density that occurs in childhood are sketchy, but available data suggests that there is approximately a $45 \%$ reduction in cell density by the age of one year, and that this figure is further reduced by $25 \%$ by the age of twenty years, with $50 \%$ of this loss occurring by the age of five years.

density (about 2,500 cells $/ \mathrm{mm}^{2}$ ) is remarkably constant. ${ }^{35}$ Interestingly, it has been noted that in the rat the total reduction in endothelial cell numbers is of the same order of magnitude as occurs in humans, but the cell loss is compressed into the shorter life span of the species. ${ }^{43}$

A typical human endothelial cell measures $5 \mu \mathrm{m}$ in height, is between 18 and $20 \mu \mathrm{m}$ in width and has a round nucleus $7 \mu \mathrm{m}$ in diameter. The posterior surface is covered by a variable number of microvilli that project between 0.5 and $0.6 \mu \mathrm{m}$ into the anterior chamber. ${ }^{47}$ Oligocilia, projecting 2 to $7 \mu \mathrm{m}$ from a pair of centrioles in the posterior cytoplasm, are present on some cells (Fig. 4), particularly toward the corneal periphery. ${ }^{48,49}$ Transmission electron microscopy has shown that cells are separated laterally by a gap of about $30 \mu \mathrm{m}$, which is reduced to $3 \mu \mathrm{m}$ at the site of a gap junction toward the anterior chamber ${ }^{50}$ Focal tight junctions join the cells at the apical third of the cell, but there are no desmosomal junctions. ${ }^{51}$ When the cells are viewed from the posterior surface there is an overall hexagonal pattern with fine marginal folds, but surface parallel histological sections reveal that there are extensive and irregular interdigitations between cells. ${ }^{52}$ The anterior cell membrane of each cell is in direct contact with Descemet's membrane and, because no junctional complexes are present, endothelial cells are readily dislodged by mechanical injury. ${ }^{53}$

The endothelial cell cytoplasm is rich in organelles, suggesting active transport and protein synthesis, with large numbers of mitochondria, both rough and smooth endoplasmic reticulum, and a well developed perinuclear Golgi apparatus. Pinocytotic vesicles pass from the posterior cell membrane to be released either into the lateral cell space or through the anterior cell membrane. Their formation is temperature dependent and they are presumably concerned with the active transport of water and metabolites. Pigment granules are occasionally seen in the cytoplasm of corneal endothelial cells and are probably derived from phagocytosed melanin that has been dispersed from the iris stroma or pigment epithelium. ${ }^{54}$

A circumferential band of actin filaments localised at the apical junction may facilitate cell movement to cover endothelial defects after injury (Fig. 5) and there is an extracellular glycoprotein matrix containing fibronectin and laminin. ${ }^{55,56}$ Plasminogen activator has been detected in the cytoplasm of cultured bovine endothelial cells after injury; this may function in vivo in a fibrinolytic system to maintain aqueous circulation by dissolving fibrin clots that threaten endothelial function. ${ }^{57}$ Protein macromolecules 'float' within the lipid bilayer of the cell membrane. ${ }^{58}$ These proteins may act as antigenic sites, ion pumps or enzymes.

\section{Physiology}

\section{The endothelial pump}

The maintenance of a transparent cornea depends upon the endothelium producing a state of relative stromal dehydration. ${ }^{59}$ The proteoglycan matrix that surrounds each collagen fibre of the stroma produces an imbibition pressure $(60 \mathrm{~mm} \mathrm{Hg})$ which tends to draw water into the cornea. Tight junctions between epithelial cells form a barrier to reduce the flow of water from the tear film into the stroma, but the absence of a continuous tight junction between endothelial cells permits the free flow of aqueous into the stroma. If this water is allowed to accumulate 


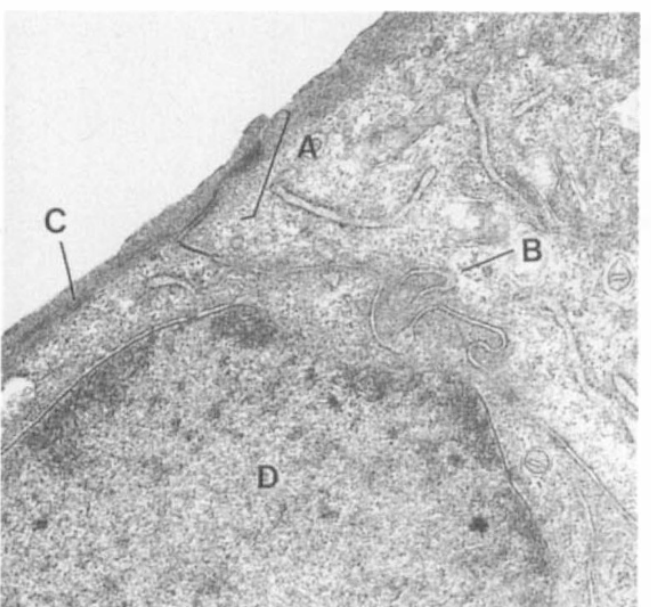

Fig. 4a.

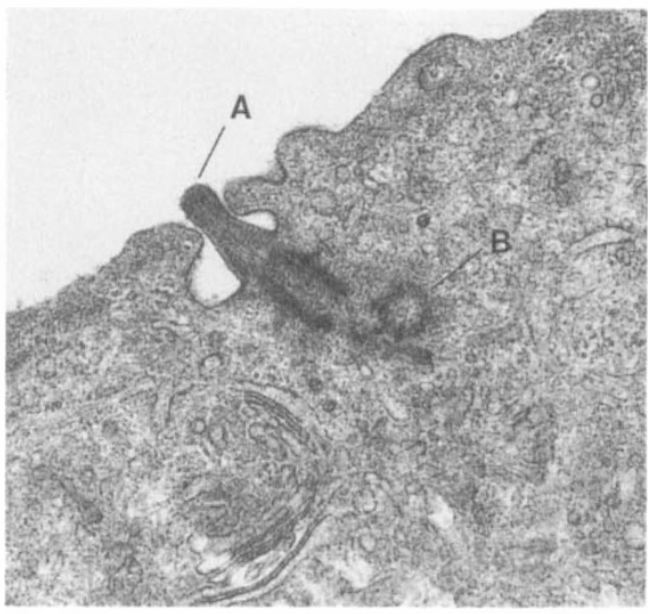

Fig. $4 b$.

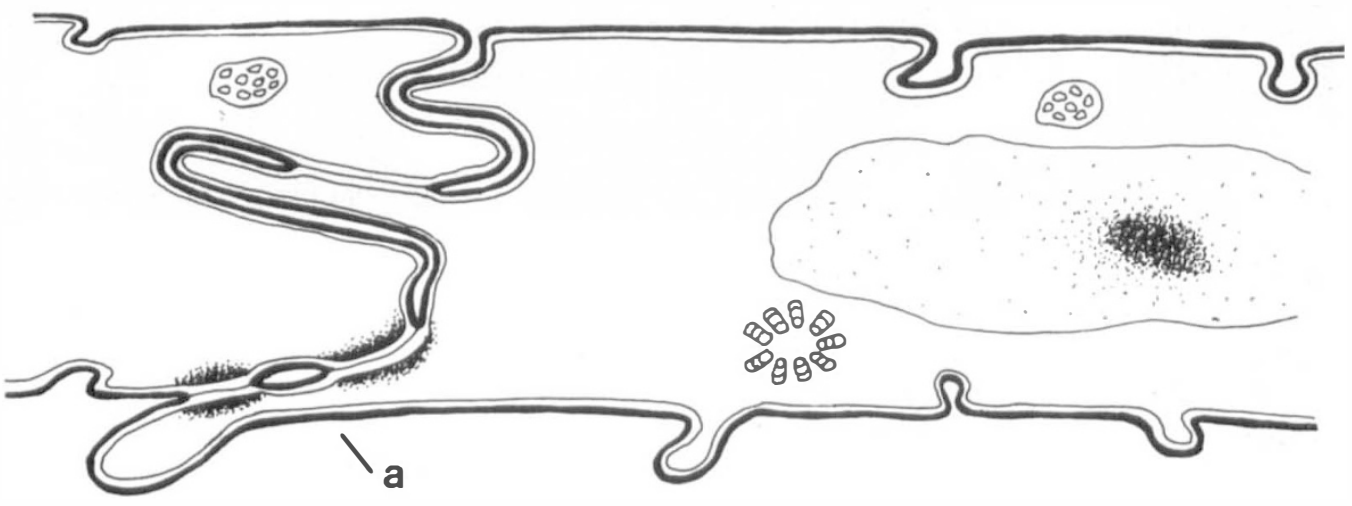

Fig. te.

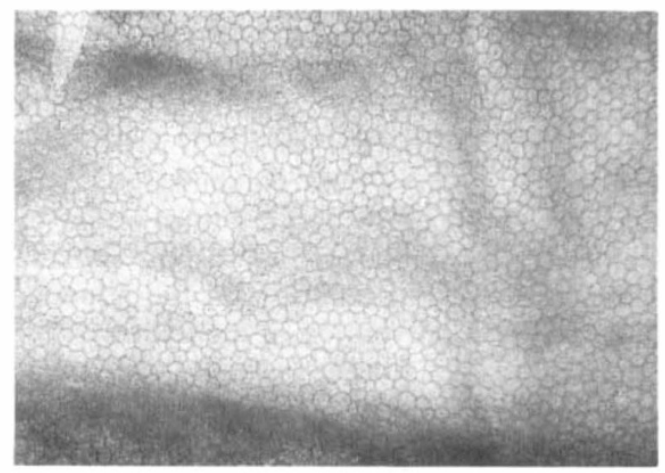

Fig. 4c.

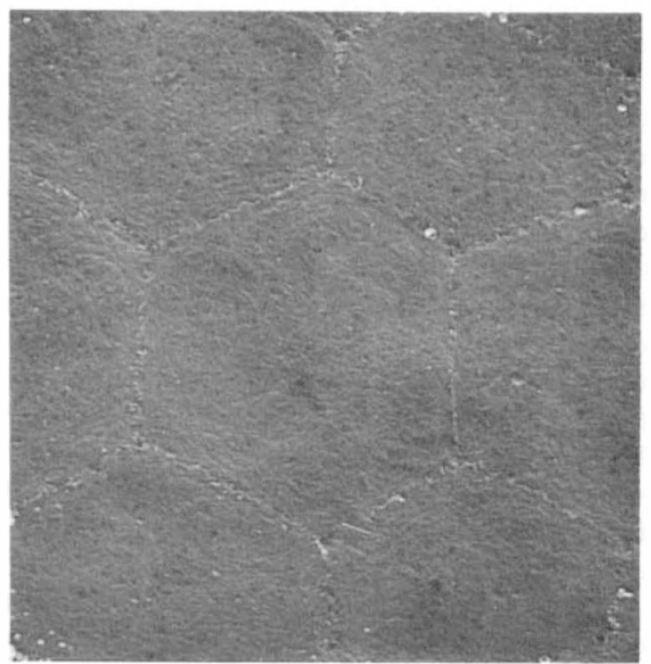

Fig. 4d.

Fig. 4. The structure of corneal endothelium. A schematic representation of a cross-section of a typical endothelial cell (centre). (a) Details of the apical junction complex showing apical complex $(A)$, gap junction (B), terminal web $(C)$ and nucleus (D). (b) The basal structure of a cilium showing cilium $(A)$ and basal complex (B). (c) Details of the surface features by specular microscopy and (d) by scanning electron microscopy. 


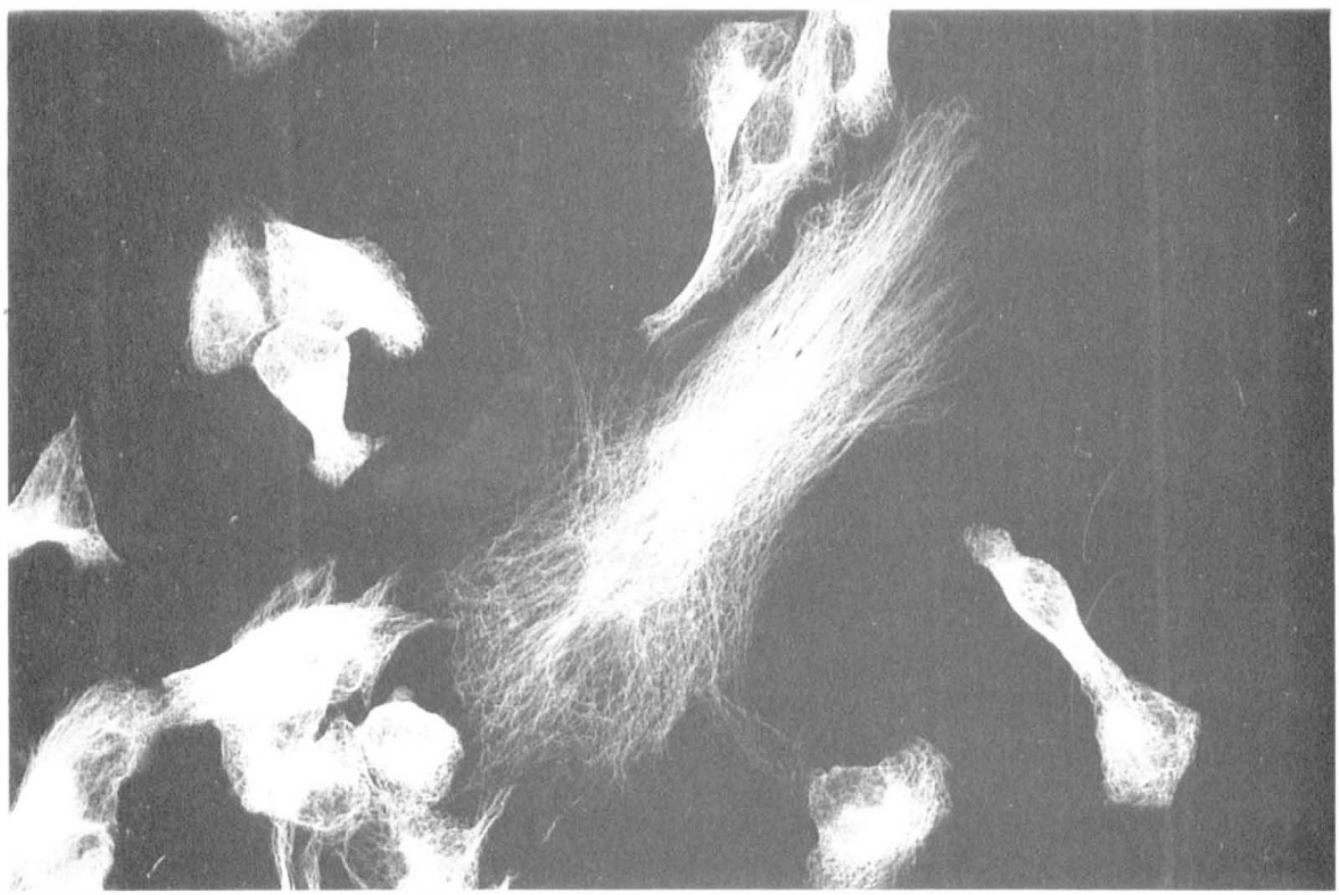

Fig. 5. Polymerized microtubules crossing the cytoplasm of migrating endothelial cells in vitro, demonstrated by immunofluorescent labelling. Nuclei appear as dark intracellular areas.

it produces stromal swelling and clouding. ${ }^{60}$ The pump-leak concept of corneal hydration proposes that there is a dynamic equilibrium between the tendency of the stroma to swell and the active transport of ions by an endothelial pump to oppose the inward movement of water. ${ }^{60}$

Fluid transport by the endothelium depends upon aerobic metabolism which can be reversibly inhibited by cooling the cornea. ${ }^{61}$ Mitochondria provide the energy to drive the system, producing ATP from glucose via the tricarboxylic acid cycle and the hexosemonophosphate shunt; the required oxygen is thought to diffuse into the endothelial cells from the anterior chamber $\left(\mathrm{pO}_{2}=55 \mathrm{~mm} \mathrm{Hg}\right)$ rather than from the tear film $\left(\mathrm{pO}_{2}=155 \mathrm{~mm} \mathrm{Hg}\right){ }^{62}$ Movement of water across the endothelium is passive, and follows the flux of actively transported ions across the posterior cell membrane. ${ }^{60}$

The metabolically active processes of deturgescence are assisted by passive mechanisms. Evaporation can increase the osmolality of the tear film and draw water from the corneal stroma ${ }^{63}$ and, in the presence of an intact endothelium, intraocular pressure is thought to compress the stroma and force water out. ${ }^{64}$.

Research has recently been directed to identify the sequence of metabolic events that determine the transparency of the cornea (Fig. 6). Insight into the selective transport of ions by the endothelium has been gained by in vivo experimentation which has either measured the trans-endothelial potential or the degree of corneal swelling induced by changes of the ionic gradient across isolated perfused corneas. ${ }^{65,66}$ Under these conditions a short circuit current (a measure of the flux of an actively transported ion) of $27 \mu \mathrm{A} \mathrm{cm}^{-2}$ is established across the membrane. This current is reduced by about a third either by the removal of exogenous carbon dioxide from the perfusing solution on the aqueous side or by the prevention of the hydrolysis of carbon dioxide with a carbonic anhydrase inhibitor.$^{67}$ It is further reduced by the removal of exogenous bicarbonate, but it appears that the contribution of metabolically derived $\mathrm{CO}_{2}$ is insignificant. ${ }^{68}$

Bicarbonate is required on the stromal side 

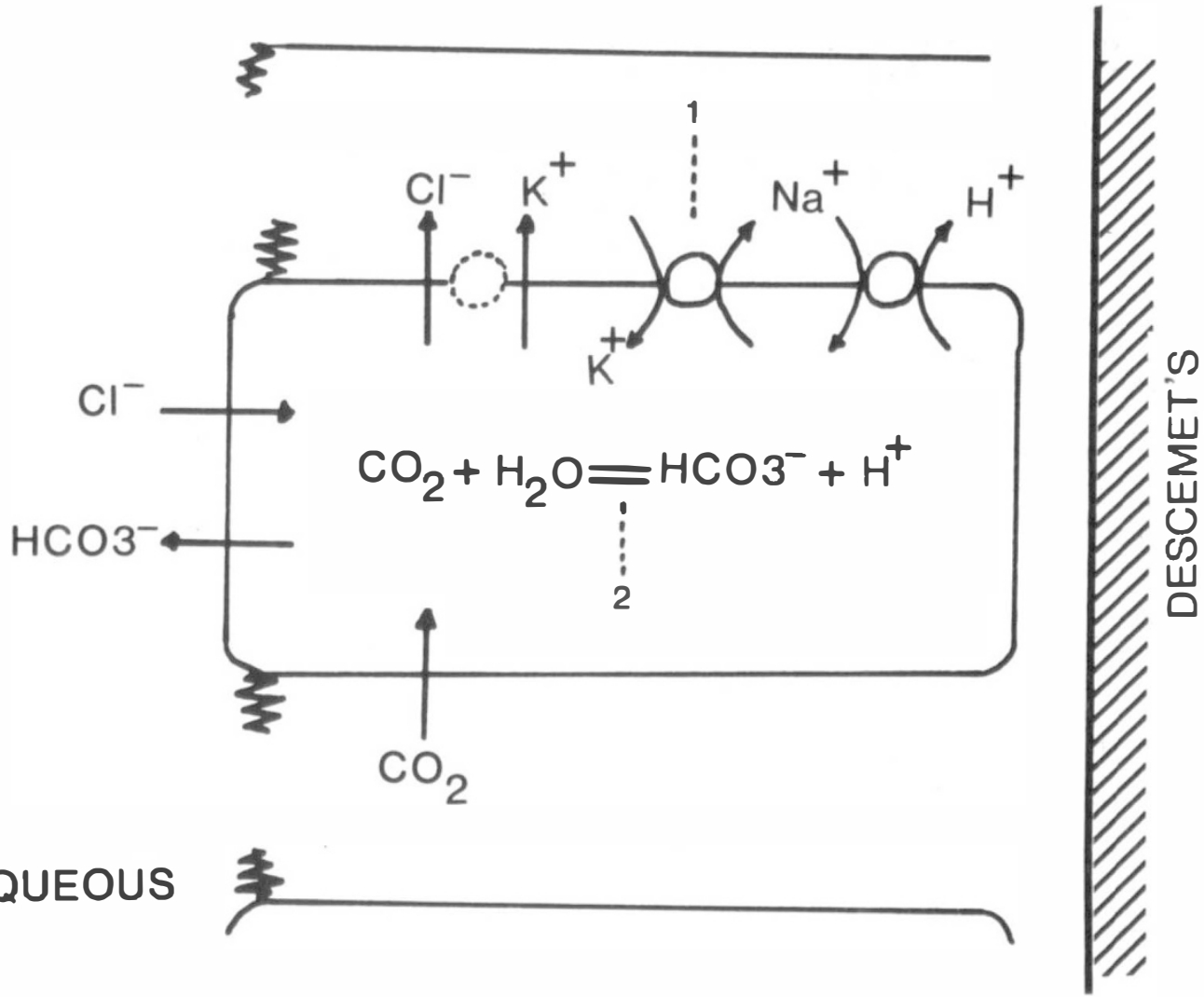

Fig. 6. Endothelial pump mechanisms. The linkage between ion flux and the mass movement of water from the stroma to the aqueous cannot be adequately explained. Although it is impossible to provide a definitive model of endothelial pumping, the following scheme summarizes aspects of our present understanding of ion transport. The pump can be inhibited by carbonic anhydrase inhibitors (1) or by ouabain (2).

of the endothelium to maintain endothelial pump function and there is a net flux of bicarbonate ions from the stroma to the aqueous. ${ }^{64,65,66,67}$ Such data has led to the concept that the movement of bicarbonate is the substrate for the endothelial pump, ${ }^{65,67,69,70,71,72}$ although it is recognised that sodium and potassium could influence fluid transport (Fig. 6). ${ }^{73,74}$ A specific bicarbonate-dependent ATPase pump has been identified, but it is associated with mitochondrial membranes, ${ }^{75,76}$ and it is thus difficult to envisage a contribution by this pump to transcellular ion flux. The mechanism of the linkage of this anionic pump to an energy source, and hence to bulk fluid flow, is not understood.

Two observations argue against a simple bicarbonate pump model. Firstly, the removal of sodium from the aqueous humour inhibits fluid flow across the endothelium and causes a significant decrease in the short circuit current. ${ }^{65,71}$ Secondly, ouabain, which irreversibly blocks the sodium-potassium ATPase pump, abolishes the short circuit current. ${ }^{75.77,78}$ Thus sodium undoubtedly has an important role. If a cation such as sodium were to be pumped into the aqueous as a primary substrate, a standing potential would be established across the endothelium, with the aqueous side positive, but in the rabbit there is a standing potential of the order of $580 \mu \mathrm{V}$ of the opposite polarity across the intact endothelium. If sodium were to be pumped into the aqueous, but could diffuse back into the stroma, it would be possible for a sodium-potassium ATPase pump to drive 
the transport of bicarbonate. ${ }^{79}$ However, an understanding of the nature of the linkage between the sodium and bicarbonate systems awaits elucidation. ${ }^{80,81}$ An alternative theory of enzymatically mediated sodium-bicarbonate exchange at the anterior cell membrane is currently attracting interest, while the active transport of sodium at the baso-lateral membrane by an ouabain-sensitive sodiumpotassium ATPase pump is being reappraised..$^{82,83}$

The number of ionic pump sites per endothelial cell may vary in certain circumstances. In Fuchs' dystrophy, there is an increase in the pump function of the endothelium in the early stages of the disease, despite a gradual dęterioration in cell density, but pump sites are markedly reduced in the end stages coinciding with the onset of corneal oedema. ${ }^{84,85,86}$

Water normally enters the stroma transcellularly or via the intercellular space. ${ }^{87}$ The removal of calcium from the aqueous results in a rapid influx of water and stromal swelling, which corresponds with the rapid disintegration of the microfilaments of the junctional complex. ${ }^{88,89}$ The absence of glutathione, a tripeptide, has a similar effect. ${ }^{90}$ Glutathione also appears to stimulate the endothelial pump, possibly by preventing the reduction of intracellular ATP.

\section{The assessment of endothelial function}

Light and electron microscopy can demonstrate the morphology of endothelial cells, but other techniques are required to assess the endothelium as a living tissue..$^{91}$ Tests of endothelial function may be broadly divided into morphological techniques, for guaging the number and shape of endothelial cells, and functional tests that measure their metabolic capacity. Qualitative tests may be further divided into tests of the pump or barrier mechanisms of the endothelium.

\section{Specular microscopy}

In 1919, Vogt described the specular appearance of normal and diseased corneal endothelium. ${ }^{92}$ Routine slit-lamp examination of the endothelium is simple and adequate in most clinical situations, but in more demanding circumstances, modern specular or con- focal microscopes permit study of the endothelium from a high resolution photographic image. ${ }^{93,94}$ The surface detail and extra-cellular features may be visualised, and posterior corneal rings, an artefact of applanation, permit the relocation of individual cells. ${ }^{95}$

As already stated, cell density measurements in isolation correlate poorly with patient age or the ability of the endothelium to maintain corneal deturgescence, but computer-assisted morphometric analysis of a digitised image is a more sensitive indicator of endothelial damage. As part of a morphometric analysis, individual cell areas can be plotted against their frequency in a given population to give a distribution curve. An increase in the frequency of abnormally large cells produces a curve skewed to the right, and a 'coefficient of skewness' can be quantified. ${ }^{96}$ Other new terms have been introduced to describe features of the cell mosaic: 'polymegathism' refers to irregularity of the mosaic due to the presence of abnormally large cells and 'hexagonality' refers to a tendency toward a regular hexagonal pattern that affords the greatest packing with optimum cell to membrane ratio. ${ }^{97,98}$ There is a positive correlation between these two parameters whereby larger endothelial cells also have a more variable shape. A departure from a homogeneous population appears to be associated with a reduced ability to withstand trauma but further studies are being conducted to determine which parameter best reflects endothelial function.

Specular microscopy has greatly increased our understanding of endothelial pathology by providing an estimate of cell density before and after surgery. The impact of this information upon anterior segment surgical techniques, the design of intraocular lenses, and the constitution of intraocular irrigating fluids and medications has been marked. However, specular microscopy does have limitations, most notably the degradation of the image by stromal oedema when an estimate of cell morphology would be most useful. Serious sampling errors may occur because of regional variations in cell density, particularly when using the small image size of some non-contact microscopes. ${ }^{99}$ Sampling error has been partly overcome by using wide field $\left(1 \mathrm{~mm}^{2}\right)$ 
examination and by relocation of the image using posterior corneal rings. A good correlation between endothelial morphology and functional performance has not been identified. Certainly, until cell numbers become low, there is a poor correlation between density and corneal thickness. Therefore, although specular morphometry has helped identify some of the caveats of intraocular surgery, it does not have a role in routine preoperative examinations, where an assessment of endothelial density made from visualisation of the specular image at the slit-lamp is adequate. $^{100}$

\section{Endothelia function and hypoxic stress testing}

The linear relationship between stromal hydration and thickness means that corneal thickness can be used as an index of endothelial damage after surgery. ${ }^{101,102,103,104}$ Similarly, the physiological function of the endothelium can be assessed experimentally by measuring changes in corneal thickness following hypoxic stress. Corneal hypoxia is produced by exposing the anterior surface of the cornea to an atmosphere of nitrogen or by placing a thick contact lens onto the eye..$^{105}$ Anaerobic metabolism by the epithelium leads to an accumulation of lactic acid which causes the corneal stroma to swell, either by directly inhibiting the endothelial pump or by creating an osmotic imbalance. ${ }^{106,107}$ Upon restoration of air to the anterior surface, the cornea thins over the following one to two hours at a rate consistent with endothelial cell pumping (Fig. 7). Evaporation augments the deturgescence response by increasing the osmolarity of the tear film; ideally, the relative humidity during the experiment should be controlled. The induced changes in corneal thickness are small and require accurate pachymetry, ${ }^{108}$ but if careful sequential measurements are made the technique can provide an indication of the capacity for deturgescence. ${ }^{109}$

The results of such studies have shown that, where there is a low endothelial cell density, a large corneal swelling response to hypoxia and a slow recovery occur. There is also a reduced recovery with increasing age. ${ }^{110}$ Nevertheless, the correlation between the rate of recovery and endothelial cell morphology is poor. The corneal swelling response is slightly reduced by aphakia, which may reflect an increased oxygen availability to the anterior chamber following cataract extraction or reduced corneal innervation. ${ }^{111,112}$

The main reservation about the use of induced hypoxia to study corneal function concerns the fear that it may precipitate irreversible corneal oedema in some patients with low endothelial cell counts.

\section{Corneal fluorophotometry}

A quantitative assessment of the endothelium may be made by measuring the passage of fluorescein across the endothelial layer. This is said to be a test of the endothelial 'barrier', but it is uncertain which physiological function of the endothelium this test measures as the normal endothelium does not provide a significant barrier to the diffusion of water. If fluorescein is taken orally, the rate of transit from the anterior chamber into the stroma of the cornea can be measured with a modified fluorophotometer. Alternatively, fluorescein may be drawn into the corneal stroma by iontophoresis and its appearance in the anterior chamber observed. ${ }^{113}$ In normal subjects, the values for fluorescein transfer appear to remain constant with increasing age but there

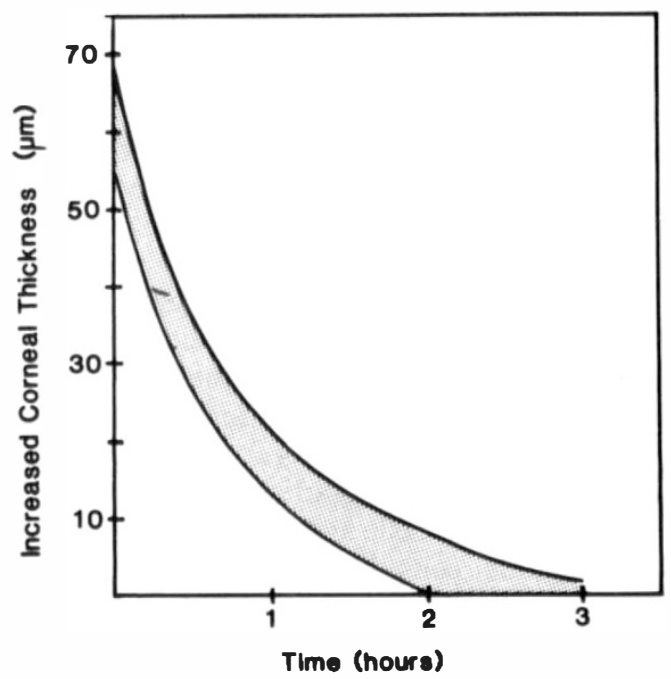

Fig. 7. Representation of the fall in central corneal thickness that occurs in the recovery phase following corneal hypoxia. Increased humidity will shift the curve to the right. 
is a correlation between an increased transfer coefficient and corneal thickness. ${ }^{114}$

Although the results of this test in the study of disease have produced some conflicting results, trends have emerged. A high fluorescein transfer has been consistently demonstrated in Fuchs' dystrophy ${ }^{115}$ and a reduced transfer in the iridocorneal endothelial syndrome. ${ }^{116}$ In general, the permeability of the endothelium to fluorescein is increased after an injury and, although an intact cell layer recovers over a period of days, the recovery of full endothelial function, as adjudged by this technique, may require months. ${ }^{117,118,119,120}$

\section{The endothelial response to injury}

Although endothelial cells are slowly lost from the cornea throughout life, decompensation seldom occurs. If episodes of injury or inflammation reduce the density below a level critical to the maintenance of corneal deturgescence, physiological function fails and corneal oedema ensues. This critical density has been estimated to be $10-15 \%$ of the normal cell count or between 300 and 500 cells $\mathrm{mm}^{2}{ }^{121,122}$ There is, therefore, a considerable physiological reserve; 500 cells $\mathrm{mm}^{2}$ is as effective as 3,000 cells $\mathrm{mm}^{2}$ in achieving corneal transparency in the short term. The mechanisms by which cell function adapts to the increased demands that follow cell loss are not understood but it may be that the number of transport sites on the membrane of each endothelial cell increases. ${ }^{123}$

Endothelial repair has been most extensively studied in the rabbit but the events of repair are similar in all species. ${ }^{124,125,126} \mathrm{~A}$ localised endothelial injury initially stimulates repair by cells in the immediate vicinity of the wound; these cells flatten and slide to cover the defect and damaged endothelial cells are desquamated into the anterior chamber (Fig. 8). ${ }^{127,128}$ As cells more distant become involved, a density gradient is established, with the largest cells at the site of the injury. Surrounding cells break their intercellular connections, develop pseudopodia and migrate at a rate of 0.5 to $1.0 \mathrm{~mm}$ per day to cover the defect, becoming flattened and attenuated in the process. ${ }^{129,130}$ These cell movements are facilitated by f-actin that polymerises across the cell cytoplasm after injury, a process that is inhibited by cytochalasin B. ${ }^{131,132,133}$ Migrating cells have an increased number of intracellular organelles, fewer endocytotic vesicles and the cells do not appear to possess a fibronectin coat. ${ }^{134}$

When cells meet in the centre of the wound, further movement is prevented by contact inhibition and a wave of cell rearrangement spreads outward. ${ }^{135}$ Mitotic figures appear at the wound edge at 16 hours, reach a peak at 24-36 hours and reduce again to zero within five days. ${ }^{129,130,136}$ Division is a major component of endothelial repair in the young rabbit $^{137}$ but in species where endothelial mitotic figures are rarely observed, such as the cat and primates, ${ }^{137,138,139}$ cell slide continues for up to one year. This complex process of cell reorganisation has been closely observed. Between four and seven days after injury, the large elongated cells at the wound margin begin to regain their original size and shape by moving relative to one another, thereby 'pulling' the more peripheral cells inwards. This sequence requires the repeated breaking and reformation of junctions between neighbouring cells, and, although a cell may become separated from its previous neighbour, macroscopic gaps do not appear in the extracellular matrix (Fig. 8). ${ }^{140,141}$

Mitotic figures have been demonstrated in the endothelium of cultured human corneas, ${ }^{142,143,144,145}$ and it is claimed that mitotic figures may be visualised in vivo with the specular microscope. ${ }^{146}$ Mitosis, however, does not occur in vivo at a rate sufficient to replace cells that are lost by ageing or injury and therefore, for all intents and purposes, the human endothelium must be regarded as a finite and irreplaceable resource. As a result of the inability to replace cells, a uniform cell distribution across the cornea may never be re-established and a vertical cell disparity, with a reduced number of cells near the wound, has been observed to persist for up to 20 years. ${ }^{147,148,149}$ In contrast, the coefficients of variation and hexagonality return towards normal within five months, suggesting the new matrix has attained stability. ${ }^{149}$ Amitotic cell division (division of the interphase nucleus without subsequent cell division ${ }^{146,150}$ ) and cell coalescence have been observed in man, ${ }^{151}$ and giant multinucleated cells can 


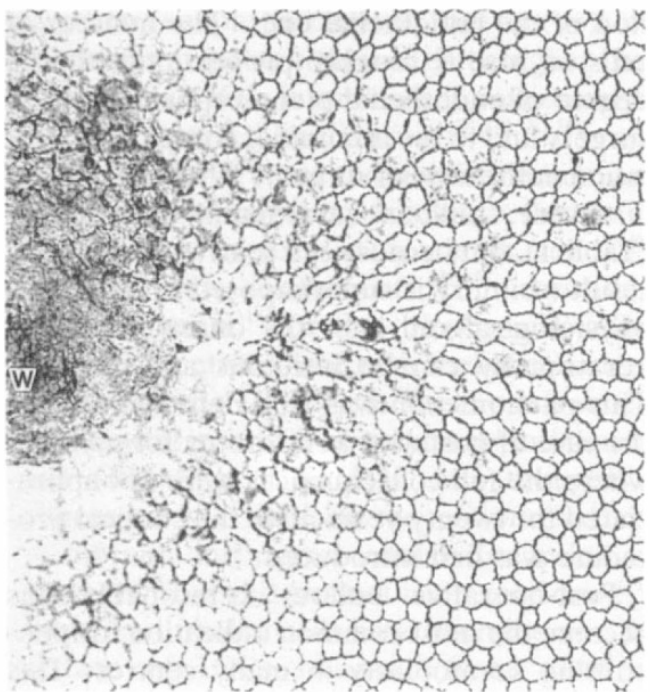

Fig. 8a.

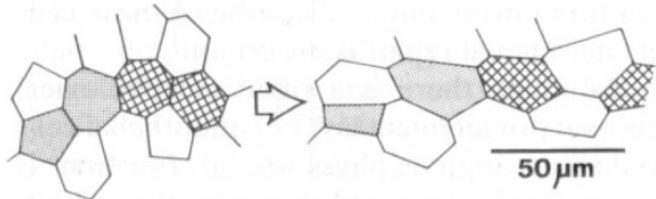

Fig. 8b.

Fig. 8. Endothelial repair occurs by endothelial cell slide, followed by some cell division to replace cells that have been lost. (a) Cells elongate and slide toward the wound (W). (b) In the process, they undergo intercellular re-arrangement. ${ }^{140}$ (c) Nuclear division may be demonstrated by the uptake of tritiated thymidine (labelled cells arrowed).

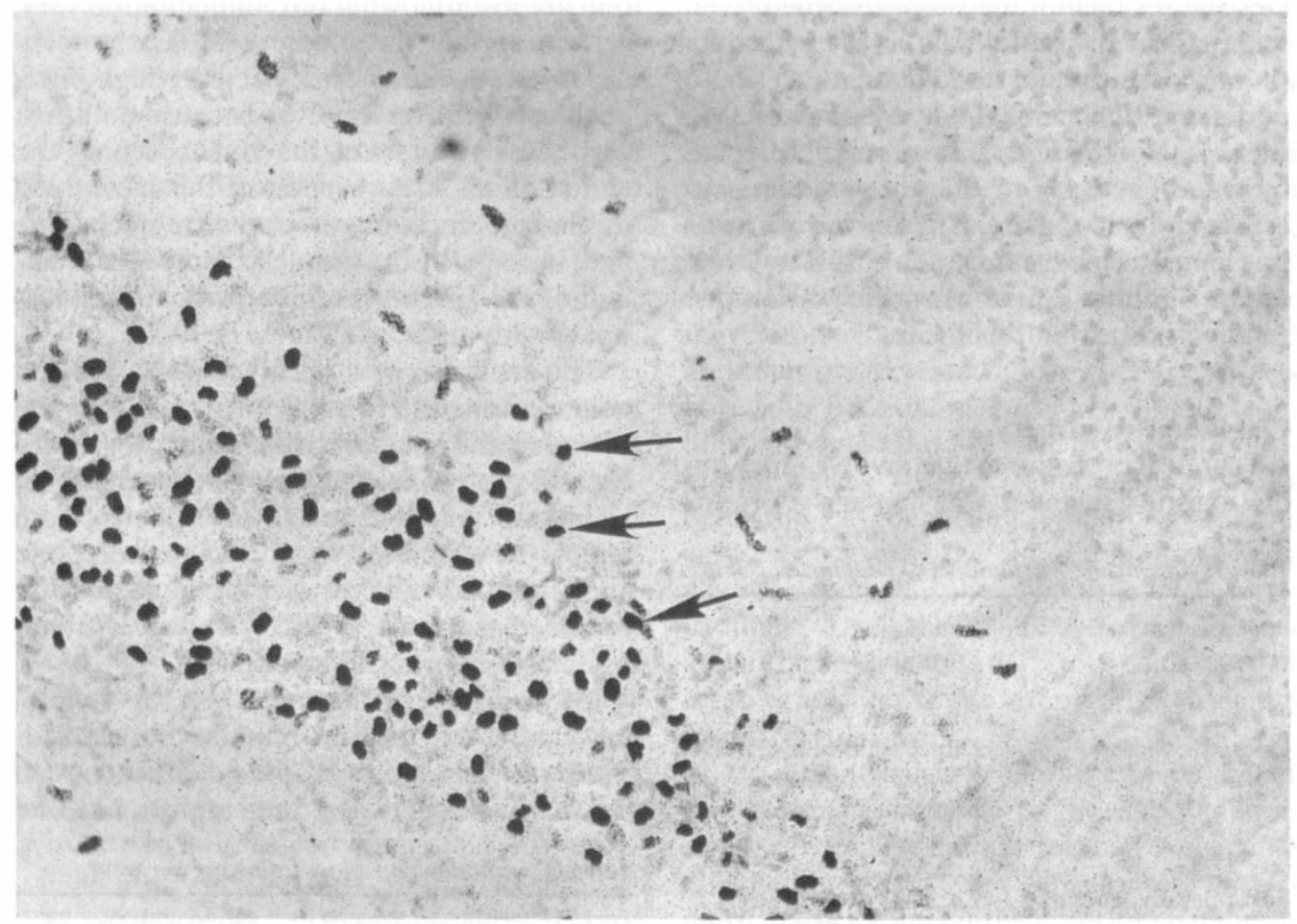

Fig. 8c. 
form following injury. The role of these cells in endothelial repair is uncertain. ${ }^{152}$

Although there is a rapid morphological recovery of an intact layer of endothelial cells following injury, physiological function is more slowly re-established. In the rabbit, where endothelial proliferation occurs, the permeability to fluorescein returns to normal within 14 days of transcorneal freezing, but there is a further delay of up to seven days before the stroma returns to normal thickness. ${ }^{153,154,155}$ In the cat, which like the human has little endothelial regenerative capacity, functional recovery may be delayed several months. ${ }^{156}$

If Descemet's membrane is damaged at the time of surgery, the cut edges retract elastically and curl toward the stroma. A fibrin clot forms on the exposed stroma, which is then covered by migrating endothelial cells. The cells covering the stromal bed secrete a new basement membrane but the damaged Descemet's membrane is not resorbed. ${ }^{157}$

Repair of the endothelial layer by cellular sliding has one major disadvantage. At sites of persistent mechanical injury caused, for example, by the leg of an intraocular lens or by a foreign body in the anterior chamber, cells migrate to the site of injury and are lostlike lemmings streaming off a cliff-and there can be a gradual spread of corneal decompensation arising from this focus.

\section{Cell loss after surgery}

All surgical procedures that involve entry into the anterior segment will damage a propor-

Table I Interacting mechanisms of endothelial cell loss

\begin{tabular}{|c|c|}
\hline $\begin{array}{l}\text { Pre-existing corneal } \\
\text { disease }\end{array}$ & $\begin{array}{l}\text { Concussion } \\
\text { Previous surgery } \\
\text { Uveitis } \\
\text { Dystrophy }\end{array}$ \\
\hline Operative factors & $\begin{array}{l}\text { Direct endothelial contact } \\
\text { with instruments } \\
\text { Intraocular lenses } \\
\text { Inappropriate irrigating } \\
\quad \text { fluids }\end{array}$ \\
\hline Post-operative factors & $\begin{array}{l}\text { Corneo-vitreal touch } \\
\text { Persistent inflammation } \\
\text { Elevated intraocular } \\
\text { pressure } \\
\text { Intermittent intraocular } \\
\text { lens touch }\end{array}$ \\
\hline
\end{tabular}

tion of the endothelial cells. The number of cells so lost is roughly proportional to the degree of endothelial pleomorphism prior to surgery and to the amount of corneal manipulation at the time of surgery. ${ }^{158,159,160}$ If cell loss is severe, bullous keratopathy may ensue (Table I), but because cell rearrangement as a result of injury is superimposed upon a slow physiological cell loss, the onset of bullous keratopathy can be insidious and delayed. This phenomenon was well demonstrated in the case of posterior keratotomy for myopia, where the full consequences were not appreciated for twenty years after the surgical procedure was first introduced. ${ }^{163}$

Post-operative bullous keratopathy has become the most common indication for penetrating keratoplasty in many centres. This has been associated with the widespread adoption of intraocular lens implantation (IOL) following cataract removal. Although figures for the percentage of endothelial cells that are lost following IOL implantation vary, certain trends have emerged. Early techniques produced an unexpectedly high operative cell loss (up to $70 \%$ ) because no effort was made to prevent the IOL touching the endothelium. ${ }^{164}$ Awareness of this hazard led to the modification of operative technique and, initially, by the simple expedient of maintaining the anterior chamber with air, cell loss was greatly reduced (Table II).

The evolution of surgical techniques aimed at minimising cell loss has been steady. If one considers the numbers of eyes that progress to corneal decompensation, improvements in technique have reduced the figure from almost $10 \%$ in early trials ${ }^{175}$ to between one and $2 \%$, or even less if iris-clip lenses are excluded from the series. ${ }^{176}$ However, longterm follow-up is still incomplete.

The question of continued cell loss following cataract extraction remains unresolved. The data suggest that a rapid fall in central cell density ceases between three months and one

Table II Estimated cell loss following surgery

\begin{tabular}{ll}
\hline Intracapsular extraction & 6 to $15 \%{ }^{165,166,167,168}$ \\
Extracapsular extraction & 14 to $23 \% \%^{166,169,170,171}$ \\
ECCE+IOL & 13 to $20 \% \%^{168}$ \\
Phacoextraction AC & $27 \%{ }^{172,173}$ \\
Phacoextraction PC & 10 to $15 \%{ }^{167,171,174}$ \\
\hline
\end{tabular}


year after simple extraction ${ }^{177}$ but that cell loss continues at a rate that is slightly higher than normal if an IOL is implanted, particularly if an iris supported lens is used. ${ }^{178,179,180,181}$

Mechanical trauma to the endothelium and incompatible irrigating fluids are the major contributory factors to operative cell loss. Contact with instruments, ${ }^{172,182}$ crystalline lens fragments, ${ }^{183}$ or the 'biophysical' adhesive effect between the endothelial cell membrane and the $\mathrm{IOL}^{184}$ are the most frequent mechanical insults. The polymethylmethacrylate (PMMA) of an IOL was thought to adhere to the lipid of the endothelial cell membrane and cause cellular disruption on contact, ${ }^{185}$ but this has not been confirmed. ${ }^{186}$ Intact endothelial cells have been seen on the surface of IOLs removed from cases of pseudophakic bullous keratopathy, but it is uncertain whether these represent cells dislodged at the time of the original surgery or cells that have subsequently migrated onto the surface of the lens. ${ }^{187,188}$ Interestingly, a coating of protein and cells on the surface of an IOL may alter the surface characteristics of the PMMA, making it less lipophilic and providing some degree of protection should there be inadvertent contact with the endothelium during subsequent surgery. ${ }^{189}$ By coating a hydrophobic IOL with hydrophilic substances, ${ }^{190}$ such as autologous plasma, ${ }^{191,192}$ methylcellulose ${ }^{184,193}$ chondroitin sulphate, ${ }^{194}$ or hyaluronic acid, ${ }^{195,196}$ this adhesive effect is reduced. An alternative approach toward safer IOL insertion is to make lenses of a hydrophilic polymer, such as hydroxymethylmethacrylate (HMMA). ${ }^{185,197}$

Penetrating keratoplasty for aphakic bullous keratopathy is generally technically successful, with up to $95 \%$ clear grafts at two years. ${ }^{198,199,200}$ The visual results are less encouraging, with only between 15 and $40 \%$ of patients achieving a best corrected visual acuity of $6 / 12$ because of associated cystoid macular oedema and glaucoma. ${ }^{198,199,200}$ Likewise, up to $80 \%$ of corneal grafts for pseudophakic bullous keratopathy remain clear at two years, with between 17 and $50 \%$ of patients having a visual acuity of $6 / 12$ or better. ${ }^{176,201,202,203}$ The visual prognosis is worse with iris supported lenses ${ }^{204}$ but, in the absence of intraocular inflammation or cys- toid macular oedema, there is no evidence that removal of a securely fixed lens will improve the final visual outcome or affect graft survival. ${ }^{201,205,206}$ Meticulous anterior vitrectomy may be required at the time of grafting to prevent vitreocorneal touch and continued endothelial cell loss. ${ }^{207}$

Prolonged intraocular manipulation usually requires the intracameral use of potentially harmful substances that may contribute to cell loss. To avoid damaging the endothelium special care must be taken to ensure that irrigating fluids have a correct ionic balance (200 to $400 \mathrm{mOsm}$ ), a correct $\mathrm{pH}$ (6.8 to 8.2), and that calcium and glutathione are present. Preferaby, an energy source should also be available. ${ }^{208,209,210}$ Because the endothelial pump is temperature dependent, cooling by irrigating fluids can slow the metabolism and produce corneal oedema which obscures the surgeon's view, but even prolonged irrigation with cold physiological fluids $\left(4^{\circ} \mathrm{C}\right)$ produces few permanent changes. The preservatives for medications intended for ocular use have a dose-dependent toxicity. Sodium bisulphite, the buffer and antioxidant frequently used with adrenalin, is toxic to rabbit endothelium after intracameral injection or perfusion at concentrations of greater than $1: 5,000,{ }^{210,211}$ while thimerosol and benzalkonium chloride may damage the endothelium at the accepted antimicrobial concentrations. ${ }^{212}$ Toxic effects have also been demonstrated after sub-conjunctival injection. ${ }^{213}$ The toxicity of antibiotics varies widely, gentamicin probably being the least damaging. Other preparations whose effect upon the endothelium has been studied include phenylephrine, ${ }^{214}$ acetylcholine,${ }^{215}$ carbechol ${ }^{216}$ and urokinase. ${ }^{217}$ As a general rule, it is unsatisfactory to use any of these drugs unless in a preparation designed for intraocular use.

Air introduced into the anterior chamber during surgery is toxic to the endothelium. Animal studies demonstrate a reversible effect after contact for 30 minutes, with a more marked effect if the anterior chamber is filled with air that is allowed to resorb. Agents introduced into the eye following vitrectomy can damage the endothelium; the effects of sulphur hexafluoride $\left(\mathrm{SF}_{6}\right)$ gas are probably 
similar to those of air, but perfluoropentane $\left(\mathrm{C}_{3} \mathrm{~F}_{8}\right)$ is more toxic because it is only slowly resorbed. ${ }^{218,219,220,221,222}$ The presence of the lens provides protection against intraocular gas during pars plana vitrectomy. ${ }^{223}$ If silicone oil passes into the anterior chamber it has a markedly toxic effect upon endothelium. ${ }^{224}$

Acute local endothelial damage undoubtedly occurs following 'minor' surgical procedures to the anterior segment, for example peripheral iridectomy or trabeculectomy, but it is rare for there to be a reduction in central endothelial cell density. Mechanical damage to the endothelium has been recorded following both continuous wave (Argon and Krypton) and short-pulsed (Nd/YAG or excimer) laser irradiation, but the long-term clinical significance of this is uncertain. Continuous wave lasers most frequently cause damage during peripheral iridectomy and trabeculoplasty, ${ }^{25,226}$ when heat is conducted from adjacent pigmented structures. ${ }^{227}$ Shortpulsed lasers produce damage when generated shock waves travel through the tissue or when high velocity tissue debris is emitted from the point of focus. ${ }^{228,229,230,231}$

\section{The endothelium and penetrating keratoplasty}

An essential objective of penetrating keratoplasty is the transfer of viable endothelial cells, and their subsequent preservation is the necessary preoccupation of the corneal transplant surgeon. The number of endothelial cells transferred on a graft is related to the status of the donor, in particular the donor age, and whether the eye has suffered any previous trauma. Endothelial cell numbers are also affected by the way the cornea is treated at the time of removal, the time elapsing between death and storage, the nature of the storage medium, and the time in storage. Subsequent cell loss occurs as a direct consequence of surgical manipulation, post-operative inflammation or allograft rejection.

\section{The assessment of excised corneas prior to corneal grafting}

In the absence of an accurate method for assessing the functional capacity of the endothelium of donor corneas, young donors are usually selected. This preference hinges upon the belief that a high cell density provides a reserve against subsequent cell loss, although there is a wide variation in endothelial cell density within any age group and a young donor does not guarantee a high initial endothelial cell count or an improved long-term cell density. However it has been noted that grafts from older donors usually require a longer post-operative period to attain their final thickness, ${ }^{232,233}$ an observation that may reflect the reduced ability of the ageing endothelium to re-form intercellular junctions. Although advanced donor age does not preclude the use of a cornea for grafting, the life span of a transplanted endothelial cell is, as yet, unknown.

The accurate prediction of the functional performance of a donor cornea is a desirable but, as yet, unattainable goal. Specular microscopy permits a direct measurement of preoperative cell density and the identification of pathology such as cornea guttata, keratic precipitates, Descemet's folds and areas of cell loss, each of which may adversely affect graft outcome. The metabolic state of tissue prior to grafting has been investigated using the nuclear magnetic resonance (NMR) of ${ }^{31} \mathrm{P}$-Phosphorus to assess the abundance of organic high energy phosphate metabolites (ATP) in donor corneas. ${ }^{234}$ Unfortunately, because of the low tissue mass of the endothelium and the high signal from the metabolically active epithelium, the technique does not resolve the endothelial response as distinct from the response of the whole cornea. The NMR of de-epithelialised corneas labelled by incubation with ${ }^{13} \mathrm{C}$-Glucose could provide a more sensitive alternative. ${ }^{235}$

\section{The endothelial cell response to grafting}

Endothelial cells are readily dislodged from a donor button by surgical manipulation, and longitudinal studies show an exponential fall in the central cell density as cells migrate to cover gaps in the endothelial layer. Following grafting for keratoconus, where there is a high endothelial cell count on the recipient cornea, a central cell loss of at least 20 to $30 \%$ occurs on the graft during the first three postoperative months. This rises to between 50 and $60 \%$ by the end of the second 
year. ${ }^{236,237,238,239,240,241,242,243}$ The rate of cell loss in subsequent years is slower, but is still greater than would be expected to occur by ageing processes alone. ${ }^{244}$ This cell loss is not the result of sub-clinical rejection and it is not prevented by topical steroids. ${ }^{242}$ When the recipient endothelial cell count is low, as in bullous keratopathy, endothelial cell loss continues at an accelerated rate which is reflected in the poor long-term results for grafting of the condition. ${ }^{245}$ Whether this is due to a late re-distribution of cells from the graft to the host cornea or continued inflammation is unclear.

The mechanisms of endothelial repair following the insertion of a corneal graft are not fully understood. Nuclear labelling experiments and sex chromatin studies demonstrate that the host and donor populations of endothelial cells move in both directions across the corneal wound but do not intermingle. ${ }^{246,247,248,249}$ In the rabbit there is extensive migration, ${ }^{250}$ and the available data suggests that a similar mechanism is present in humans. However, following grafting for keratoconus there is usually a higher final cell density on the host than on the donor cornea and a uniform cell density is never attained. ${ }^{251,252,253,254}$

Allograft rejection is the commonest cause of corneal graft failure. ${ }^{255}$ Although grafts placed into corneas which have never been inflamed or vascularised seldom reject, unlike grafts for keratoconus, grafts placed in a recipient bed which has been inflamed or vascularised are often rejected. ${ }^{256,257}$ The basis of this loss of corneal privilege is related to the accumulation of immunocompetent cells, particularly interstitial dendritic cells, in the diseased recipient cornea. ${ }^{258}$ These 'passenger cells' present foreign antigens to the host immunocytes - the first step on the afferent path of the allograft response. ${ }^{259}$ Following sensitisation, the efferent response is largely directed at the endothelium. Endothelial rejection appears clinically as either a diffuse uveitis with scattered keratic precipitates or as a rejection line enclosing a specific point of sensitisation, such as an iris synechia or vascular ingrowth. ${ }^{255}$ Treated promptly and aggressively with steroids or antimetabolites, the rejection may be halted, with the reappearance of a clear graft, but an abnormal appearance of the specular image persists. ${ }^{260}$ Following severe rejection, a posterior collagenous layer is deposited beneath the endothelium and extensive cell loss may result in persistent oedema. ${ }^{261,262}$

Despite the role of the endothelium as a target for the allograft reaction, there is doubt as to the identity of the target antigens. Although most studies have reported that class I antigens are absent from adult corneal endothelium, ${ }^{263,264,265,266,267}$ there are notable exceptions. ${ }^{268,269}$ There is agreement, however, that class I antigens can be found on the endothelium of donors younger than two years of age. ${ }^{263,269}$ Class II antigens are not expressed on healthy endothelium, but there is evidence that they can be induced under the influence of regulatory cytokines ${ }^{270,271}$ and in rejected corneas. ${ }^{272}$ Increased expression of class I and class II antigens has previously been shown to occur in other tissues during rejection ${ }^{273,274,275}$ and class I antigens can be upregulated after surgery alone. ${ }^{275}$ It would therefore appear that the endothelium does hold the target major histocompatibility antigens for rejection but that they are only expressed under certain conditions which predispose to allograft rejection.

The transplantation of endothelial cells onto a patient's own cornea has been proposed as a technique to reduce the antigenic load of a penetrating keratoplasty. In rabbits, cultured endothelial cells can be seeded onto thin gelatine sheets and, when a confluent monolayer has grown, the sheet affixed to the back of a donor cornea. ${ }^{276}$ Alternatively, the cultured endothelial cells may be seeded directly onto exposed Descemet's membrane. ${ }^{277}$ Both homografts and xenografts of corneal endothelium have had short-term success in experimental animals, but the clinical applications remain distant. It should be noted that endothelial cells express class I antigens after culture. ${ }^{263,278}$ Experiments to seed the posterior corneal surface of cats with autologous vascular endothelial cells have not produced grafts that remain clear, ${ }^{279}$ and there is no evidence that vascular endothelium can assume a pump capacity comparable to corneal endothelium.

The synthesis of peptide mitogens that 
stimulate the proliferation and differentiation of endothelial cells after injury has been demonstrated in cell culture. ${ }^{280}$ Although these peptides appear to have developed as a local regulatory system, cells can also respond to added growth factors and these have been used to stimulate the low replicative capacity of human corneal endothelium. A mitogenic effect upon endothelium in culture has been demonstrated for fibroblastic and epidermal growth factors, ${ }^{281,282,283}$ and priming tissue with these polypeptides may yield a higher final endothelial cell density after grafting. ${ }^{276}$ This has not been used clinically.

\section{General Considerations of Endothelial Pathology}

Despite the structural simplicity of the corneal endothelium, it is involved in a bewildering range of diverse but often interrelated pathologies. For the clinician, the precise classification of a particular case can be difficult. This is partly because any classification tends to be descriptive as so little is known of the aetiology of these conditions. Furthermore, the terminology of general pathology is not always appropriate.

For the general pathologist, a dystrophy may be defined as a disorder, usually congenital, of the structure or function of an organ or tissue due to a perverted nutrition. In its widest sense it includes agenesis, atrophy, hypertrophy, hyperplasia, and metaplasia, but in practice the term is usually applied to those disorders which do not fit into any other category. In ophthalmology, the corneal dystrophies are primary conditions although they may not manifest until adult life.

Several other terms deserve classification. Dysgenesis refers to conditions that are the result of an abnormal migration of formative elements. Dysplasia is a descriptive term that has been loosely applied. At times it is used as an alternative term for dystrophy, describing an abnormal growth of tissue, although it should only be applied to developmental disorders. This convention is usually followed by ophthalmologists, an exception being its use to describe changes found in the corneal epithelium that are considered to be pre-malignant. Within this framework, efforts have been made to group primary endothelial dis- eases (dystrophies) in terms of the migration (dysgenesis) or differentiation (dysplasia) of a common neural crest precursor, ${ }^{284,285,286,287}$ and thus to link the ocular and the systemic neurocristopathies (Table III).

Any of these disease processes may be accompanied by endothelial metaplasia. Metaplasia describes a change in which one cell type assumes the phenotype of another similarly differentiated tissue (Fig. 9). This may occur in the endothelium as part of a developmental disorder or it may occur in response to injury. Epithelioid metaplasia is accompanied by the loss of contact inhibition, an increased expression of keratin, and the proliferation of surface microvilli; posterior polymorphous dystrophy is the best example, but similar changes occur in the irido-corneal endothelial syndrome. ${ }^{288}$ In fibroblastic metaplasia, the normally polygonal cells become fusiform and develop prominent cytoplasmic organelles. This appears to be a non-specific manifestation of endothelial distress and attempted repair and is observed after such varied stimuli as alkali burns, transcorneal freezing, graft rejection, vitreous touch and experimental uveitis. ${ }^{289,290}$ Both types of metaplasia can be accompanied by the deposition of a posterior collagenous layer formed of long-spaced collagen. ${ }^{291}$ Although the primary source of the abnormal collagen is the endothelial cell, ${ }^{292,293}$ stromal keratocytes may contribute following rupture of Descemet's membrane. ${ }^{294}$

A peripheral migration of endothelial cells can accompany dystrophic disease (primary proliferation) or ocular injury (secondary proliferation). Primary endothelial proliferation most typically occurs in the iridocorneal endothelial syndrome ${ }^{295}$ while secondary proliferation may follow concussive injuries.

\section{Special Pathology of the Endothelium}

The time-honored convention of classifying

Table III The neurochristopathies

\begin{tabular}{ll}
\hline Abnormal migration & $\begin{array}{l}\text { Axenfeld-Rieger' anomaly } \\
\text { Peter's anomaly }\end{array}$ \\
Abnormal proliferation & ICE syndrome \\
Abnormal differentiation & CHED \\
& PPMD \\
& Fuchs' dystrophy \\
Acquired abnormality & Metaplasia \\
\hline
\end{tabular}



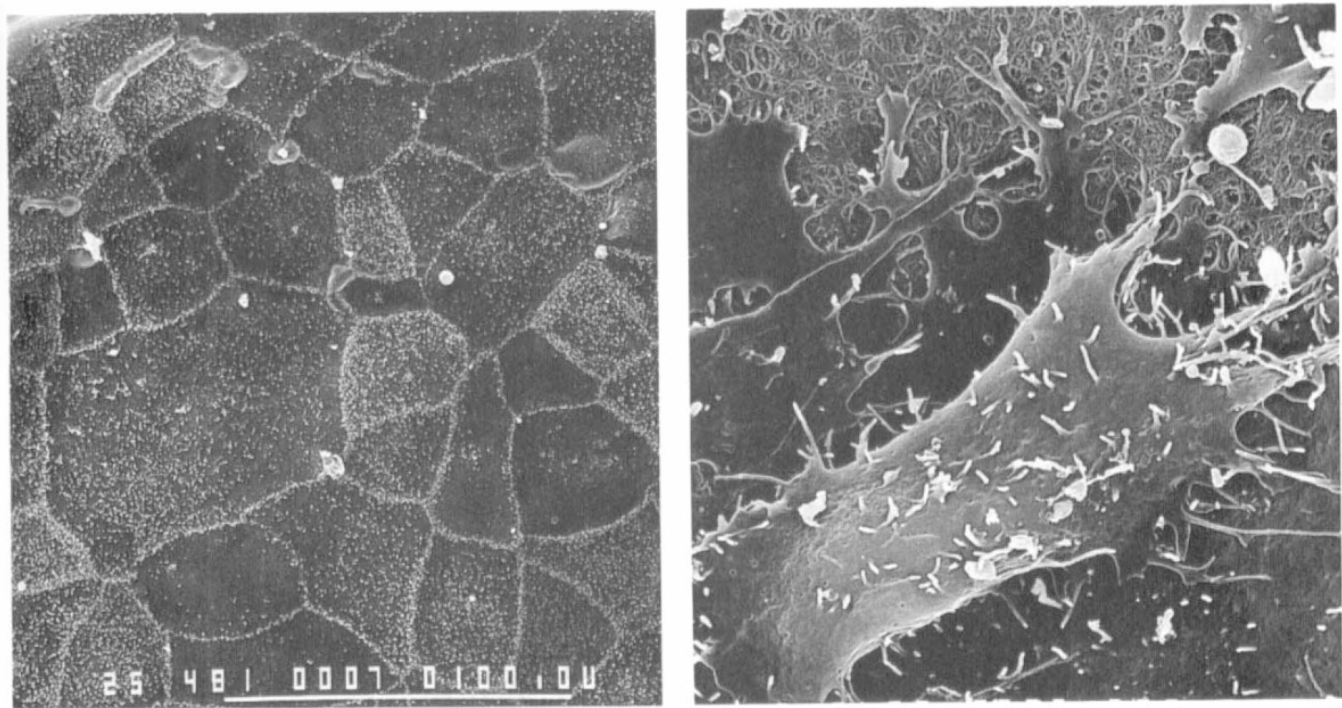

Fig. 9. (a) Diseased endothelium may develop an irregular mosaic with numerous microvilli on each cell, an appearance that may superficailly resemble epithelium. (b) A fibroblastic configuration with the deposition of collagen is a non-specific feature of endothelial distress.

disorders as developmental or acquired is appropriate for the conditions which specifically affect the normal endothelium.

\section{Developmental Conditions}

Mesenchymal dysgenesis (Anterior chamber cleavage syndrome)

Mesenchymal dysgenesis presents as bilateral malformations of the anterior segment which are transmitted with an autosomal dominant or sporadic mode of inheritance. A radially symmetric arrangement points to an anomaly of the first wave of neural crest migration as the cause for the ocular signs, ${ }^{296,297}$ but the presence of non-ocular features involving the teeth, facial bones and melanocytes indicates a more generalised abnormality of neural crest derivatives. ${ }^{298} \mathrm{~A}$ combination of several structural abnormalities produces a gradation of related syndromes: the Axenfeld-Rieger syndrome; posterior keratoconus; Peter's anomaly; sclerocornea; and trabeculodysgenesis (congenital glaucoma). Each incorporates a degree of dysplasia of the endothelium with an abnormal Descemet's membrane. Individuals often exhibit features that suggest an overlap between the syndromes which emphasises their common aetiology. ${ }^{299}$
The Axenfeld-Rieger syndrome is the least severely affected variant. There is only mild pleomorphism of the size and shape of the endothelial cells, Descemet's membrane can be attenuated, and an abnormal layer of collagen covers the prominent Schwalbe's line. These defects could represent an abnormal retention of primordial portions of the iris and anterior chamber angle (Table IV).

At the other end of the spectrum of disease, Peter's anomaly demonstrates the most severe form of dysgenesis with widespread maldevelopment of the anterior segment. Up to $80 \%$ of patients with Peter's anomaly have bilateral involvement ${ }^{300}$ and between 50 and $70 \%$ of cases develop a secondary glau-

Table IV Features of mesenchymal dysgenesi s $^{296,297,300}$

\begin{tabular}{|c|c|}
\hline $\begin{array}{l}\text { Axenfeld-Rieger } \\
\text { syndrome }\end{array}$ & $\begin{array}{l}\text { Prominent and anteriorly } \\
\text { displaced Schwalbe's } \\
\text { line } \\
\text { High insertion of iris } \\
\text { Corectopia } \\
\text { Hypoplasia of iris with } \\
\text { holes }\end{array}$ \\
\hline Peter's Anomaly & $\begin{array}{l}\text { Corneal leukoma } \\
\text { Corneal-lenticular } \\
\text { adhesions } \\
\text { Anterior polar cataract } \\
\text { Shallow anterior chamber } \\
\text { Scleralisation of cornea }\end{array}$ \\
\hline
\end{tabular}


coma. ${ }^{296} \mathrm{~A}$ more detailed review of the syndromes within this group is presented elsewhere. ${ }^{301,302,303,304}$

Histological examination of the posterior cornea in Peter's anomaly demonstrates an attenuation of the endothelial layer centrally, while the peripheral endothelium may be normal. Descemet's membrane is absent or represented by multiple laminations of basement membrane interspersed with collagen fibrils. ${ }^{305,306,307,308}$ Giant collagen fibrils, up to $60 \mu \mathrm{m}$ in diameter, have been noted, ${ }^{309}$ and similar fibrils have been demonstrated in both $\mathrm{CHED}^{310}$ and following experimental lensectomy in the chick embryo. ${ }^{311}$

Treatment is required in only a minority of patients. Keratoplasty and lensectomy may be required to clear the visual axis if there are corneolenticular adhesions and cataract, but the visual prognosis is poor.

\section{Endothelial Dystrophies}

\section{Congenital hereditary endothelial dystrophy (CHED)}

This is a rare disorder that presents in children or young adults as a bilaterally symmetric diffuse corneal oedema varying from a mild stromal haze to gross opacification of the cornea (Fig. 10). ${ }^{312,313}$ Judisch and Maumenee recognised differences in expression between the autosomal recessive and the autosomal dominant forms of the disease. ${ }^{314}$ The recessive variant tends to present earlier, have more severe corneal opacification, and visual deprivation can produce a pendular nystagmus. The cornea in the dominant variant may appear to be normal in infancy but oedema usually begins to develop in the first two years, although visual deterioration may be delayed. Oedema is not always progressive, but epithelial breakdown can result in photophobia and tearing, and secondary changes can produce band keratopathy and spheroidal degeneration. Associated abnormalities of the anterior segment are not a prominent feature of CHED and the primary differential diagnosis is between congenital glaucoma and a mucopolysaccharidosis. The corneal diameter in congenital glaucoma is usually larger than normal and there is a raised intraocular pressure with Descemet's breaks; the opacity in a mucopolysaccharidosis tends to be an infiltration rather than oedema.
Histological examination reveals a range of endothelial morphology. The endothelial cells demonstrate fibroblast-like changes and may be absent from the central cornea. Descemet's membrane is often represented by only the anterior banded zone and a disorganised posterior collagenous layer can be grossly thickened and beaded. ${ }^{315}$ The peripheral endothelium and Descemet's membrane are relatively unaffected. This distribution suggests that the disease is due to an incomplete central migration of endothelial precursors, with secondary endothelial metaplasia and hypersecretion of collagen.

The diameter of the stromal collagen fibres is increased and they show non-specific changes of long-standing corneal oedema. ${ }^{316,317}$ Histological similarities between CHED and posterior polymorphous dystrophy suggest that there is an overlap between the two conditions, indeed it has been proposed that the two syndromes represent the clinical spectrum of a single congenital endothelial dystrophy. ${ }^{318,319}$

The decision to perform penetrating keratoplasty depends upon the degree of stromal opacity., If there is marked opacity from birth, the operation should be performed early and an appropriate optical correction provided to reduce the period of visual deprivation and the risk of amblyopia. This type of surgery can be difficult and requires careful follow-up as graft rejection may be insidious and develop rapidly in the infant. Even with the most meticulous care, the prognosis for graft survival in young children is poor, with only about $40 \%$ of long-term grafts remaining

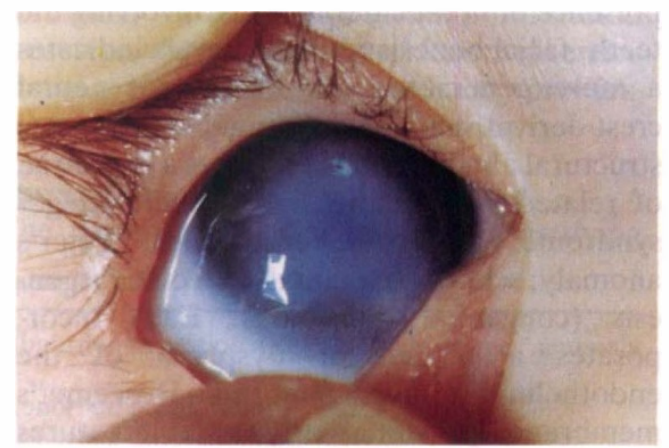

Fig. 10. Congenital hereditary endothelial dystrophy. Central corneal clouding presented at birth; the anterior segment was otherwise normal. 
clear. ${ }^{320}$ If the degree of opacity permits a delay, the prospects for successful grafting improve markedly. ${ }^{321}$

\section{Posterior polymorphous dystrophy (PPMD)}

This is a slowly progressive disorder that is most often innerited as an autosomal dominant trait, although in some instances the inheritance appears to be autosomal recessive. ${ }^{322,323}$ Involvement is bilateral, but the expression of the disease can be highly variable and asymmetric, such that early cases may appear to be unilateral. Vision is usually well preserved and only rarely does stromal and epithelial oedema develop. In some family studies vesicles and corneal oedema have been'noted at birth.

Corneal changes are best visualised with a slit-lamp using a broad tangential beam or retro-illumination (Fig. 11). At the level of Descemet's membrane, clusters of vesicular lesions are arranged in groups, scalloped geographic areas, or bands that may superficially resemble traumatic breaks in Descemet's membrane. ${ }^{324}$ A faint grey stromal haze surrounds these lesions. Two separate populations of endothelial cells can be seen at specular microscopy: large pleomorphic cells and small cells that have indistinct boundaries. ${ }^{325}$

The benign non-familial occurrence of small clusters of posterior corneal vesicles has been reported. ${ }^{326}$ These do not affect vision and are non-progressive.

The occurrence of features of mesenchymal dysgenesis, the iridocorneal endothelial syndrome (ICE), and CHED in some families with PPMD suggests a related aetiology. ${ }^{319,324,327}$ The basic anomaly of both PPMD and ICE seems to be a proliferation of metaplastic epithelioid cells, although proliferation onto the anterior iris is not common in PPMD and the two conditions vary in their morphology, transmission and natural history. ${ }^{328}$ Broad peripheral iridocorneal adhesions, a feature of some cases of PPMD, are more substantial than the finer adhesions that occur in the Axenfeld-Rieger syndrome and they are not associated with a prominent Schwalbe's line. Glaucoma rarely occurs in patients with PPMD, but when it appears it is thought to result from a proliferation of endothelium over the open angle or an anterior insertion of the iris into the trabecular meshwork-an abnormality that is more typically seen in primary congenital glaucoma (trabeculodysgenesis). ${ }^{329}$

Histopathological studies of PPMD are limited to the few cases that progress to corneal oedema. The presence of endothelial cells with epithelioid characteristics is remarkable. ${ }^{330}$ Affected cells form multiple layers and overgrow the normal endothelial cells, ${ }^{331}$ have desmosomal junctions and numerous microvilli facing the anterior chamber.

Endothelial cultures from affected corneas produce two distinct populations: cells of a normal appearance and cells having multiple microvilli. ${ }^{332}$ An increased expression of the keratin cytoskeleton has been demonstrated by immunohistochemistry in PPMD, ${ }^{333,334}$ indicating that the epithelioid cells are probably not derived from ectopic surface ectoderm but are metaplastic endothelial cells. ${ }^{335}$ The presence of only a thin posterior nonbanded Descemet's membrane suggests an onset of disease in the perinatal period. ${ }^{331,335,336,337,338,339,340}$ A thick posterior collagenous layer is deposited later and may be heaped into fusiform swellings that project into the anterior chamber or form loose fibrocellular material which fills infoldings of Descemet's membrane. Both changes can produce the clinical appearance of vesicles. ${ }^{341}$

\section{Fuchs' endothelial dystrophy}

This is the most common of the endothelial dystrophies. It is characterised in its earliest stages by guttata which appear as non-reflecting points in the specular image of the endothelium or as refractile particles on retroillumination $^{342}$ (Fig. 12). Primary -guttata appear in two patterns: isolated central guttata as part of the normal ageing process or confluent guttata accompanied by corneal oedema and reduced vision which constitutes Fuchs' endothelial dystrophy. There is a continuum of disease between these two extremes. Secondary corneal guttata may appear after corneal inflammatory disease, such as syphilitic interstitial keratitis. ${ }^{343}$

Fuchs' endothelial dystrophy is typically inherited as an autosomal dominant trait with 


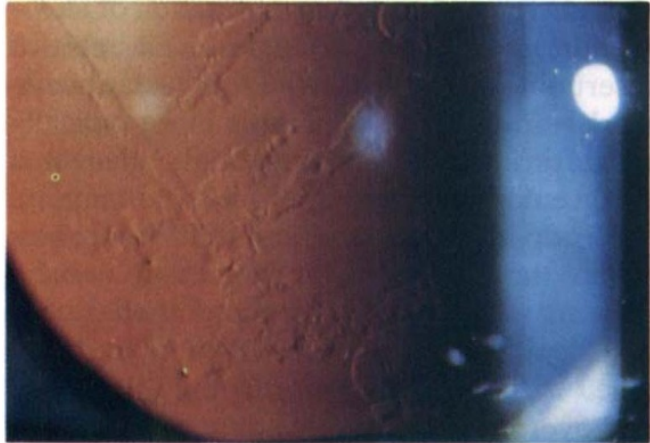

Fig. 11. Posterior polymorphous dystrophy. (a) Numerous 'vesicles' may be seen on the red reflex. (b) On specular microscopy, these appear as localised groups of abnormal cells (arrows) amidst a mosaic that has moderate polymegathism.

Fig. 11a.

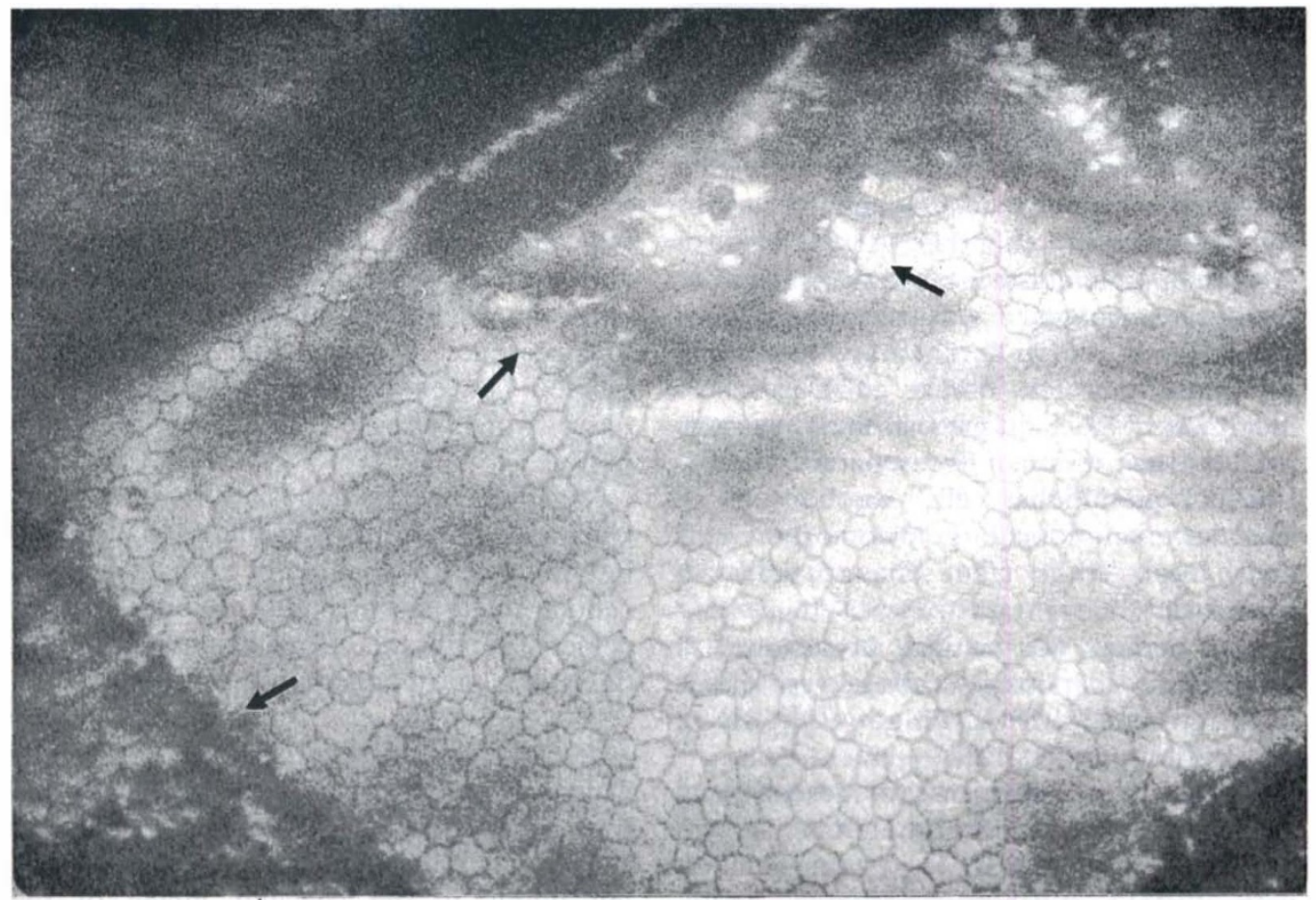

Fig. $11 b$.

incomplete penetrance, although in some series up to $50 \%$ of cases are sporadic. ${ }^{344}$ In one large series, guttata were seen in $70 \%$ of individuals over the age of 40 years, but were confluent in only $3.7 \% .{ }^{345}$ The overall female to male ratio in this series was 2.5 to one but, when only the patients progressing to surgery were considered, the ratio increased to six to one. ${ }^{344}$ Thus the disease is more common in females and the phenotypic expression is more severe. ${ }^{346,347}$ An association of Fuchs' endothelial dystrophy with chronic simple glaucoma, ocular hypertension and acute closed angle glaucoma would imply a generalised abnormality of the anterior segment, ${ }^{348}$ but other authors report an incidence of chronic simple glaucoma of only $1.4 \%{ }^{344}$ and a normal outflow facility.

Abnormalities of the endothelium are evident many years before symptoms manifest. Symptoms typically develop slowly through three stages over a period of up to twenty 


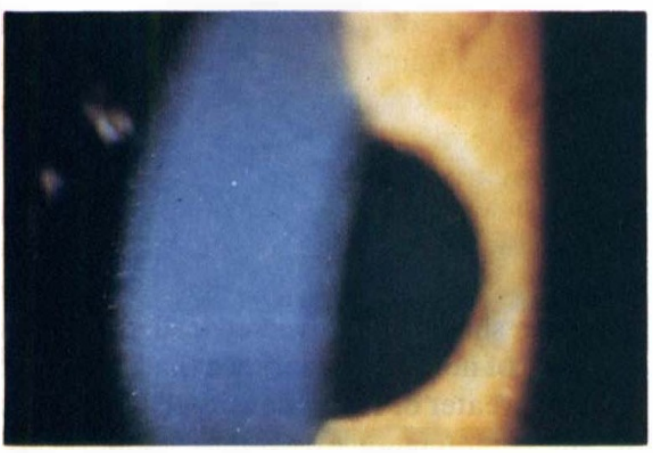

Fig. 12a.

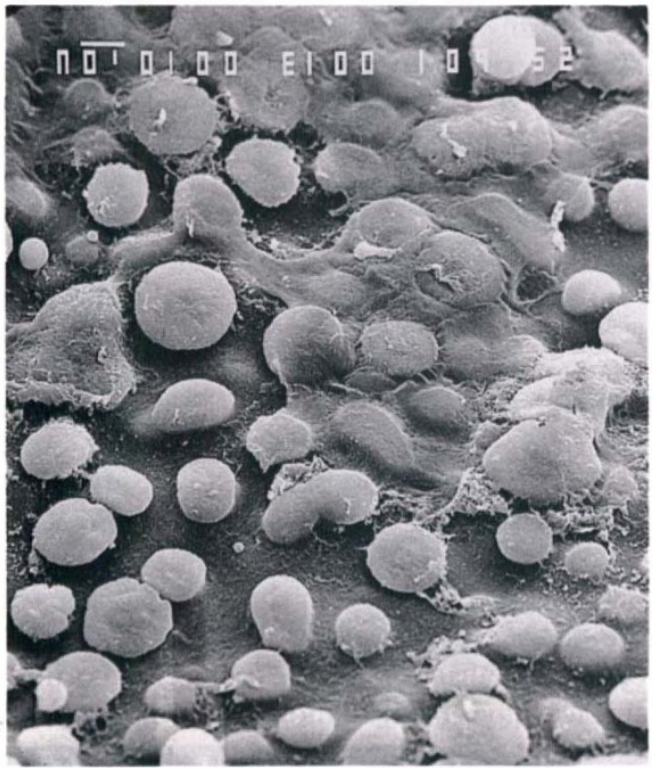

Fig. $12 b$.

Fig. 12. Fuchs' endothelial dystrophy. (a) Numerous guttata and localised stromal oedema may be seen on retroillumination. (b) Scanning electron microscopy graphically demonstrates the protruberent nature of the guttata and the way the remaining endothelial cells are at first stretched to cover them and are eventually lost.

years. The eye is initially asymptomatic as guttata appear centrally, the thickened Descemet's membrane becomes visible on tangential illumination, and pigment that has been phagocytosed by endothelial cells forms geographic patterns. During a second stage of the disease, stromal and epithelial oedema produces glare and visual loss due to irregular astigmatism and the rupture of sub-epithelial vesicles can be painfur. In the final stage, central sub-epithelial scarring results in an opaque cornea that may become secondarily vascularised.

Histological examination of Descemet's membrane shows a normal $110 \mathrm{~nm}$ banded layer anteriorly with a thin amorphous layer posteriorly. Excrescences formed of longspaced collagen protrude into the anterior chamber, although these may be subsequently buried by the deposition of a posterior collagenous layer. ${ }^{349}$ Endothelial cell loss results in an increase in the surface area of the remaining cells which become thinned. ${ }^{350}$ The intercellular spaces are widened with the loss of occluding junctions, and the development of desmosomes could represent fibroblastic metaplasia..$^{350,351,352}$ Despite the loss of junctional complexes and a decrease in the endothelial cell numbers, endothelial pump function may be significantly increased in the early stages of disease, which would delay the onset of stromal oedema. ${ }^{353,354}$

Treatment aims to control discomfort and blurred vision. Increasing the tonicity of the tear film with hypertonic drops or blowing with a hair drier may help to clear vision, and a temporary bandage contact lens can lessen the discomfort from ruptured bullae. Topical steroids have no proven beneficial effect. ${ }^{355}$ Penetrating keratoplasty should be considered when visual acuity falls to an unacceptable level. Despite the high percentage of graft successes in the early post-operative period, the long-term prognosis for keratoplasty has been reported to be poor; $; 36$ this is based on one study in which all uncomplicated grafts had become cloudy at nine years follow-up. ${ }^{357}$ Other long-term series, however, have reported success rates of up to $85 \%$ at 8 years. ${ }^{358,359}$

Viral particles have been demonstrated in one case of Fuchs' dystrophy, ${ }^{360}$ but the aetiology of the majority of cases remains unknown. Fibrinogen and fibrin deposition have been demonstrated in the posterior collagenous layer by immunofluorescence and it is possible that the fibrinolytic system of the aqueous humour adversely affects the endothelial cells. Systemic tranexamic acid, an anti-fibrinolytic agent, has been used with some success in clinical experiments to induce stromal thinning in Fuchs' dystrophy, ${ }^{361}$ but the mechanism of its action is undetermined. ${ }^{362}$ 


\section{The irido-corneal endothelial (ICE) syndrome (Primary proliferative endotheliopathy)}

The ICE syndrome is particularly difficult to classify as it does not completely satisfy the criteria for both dystrophy and dysplasia. The condition is essentially unilateral with minimal changes in the other eye; it is usually sporadic but family clusters have been described and it has a characteristic clinical appearance, with dysplastic endothelium the dominant histologic feature. Whether the condition should be considered with the dystrophies or whether it represents a true dysplasia (but grossly delayed) of the neural crest remains to be decided. For our purposes it is appropriate to consider the syndrome along with the endothelial dystrophies.

Essential iris atrophy, Chandler's syndrome and the Cogan-Reese syndrome are probably variants of a single disease process in which secondary corneal oedema, peripheral anterior synechiae and changes in the iris architecture are.the main clinical features ${ }^{363}$ (Table V). They form a group of progressive disorders collectively called the irido-corneal endothelial (ICE) syndrome ${ }^{364}$ (Fig. 13). The endothelium in this syndrome has a characteristically hammered-silver appearance in specular reflection. ${ }^{365}$

Patients with the ICE syndrome are typically young white females in their third to fifth decade. ${ }^{369}$ The female to male ratio is estimated to be as high as $5: 1^{370}$ and, interestingly, affected males tend to have bilateral involvement. Although most cases are sporadic, a familial bilaterally symmetric variant has also been described. ${ }^{371}$ Minor abnormal-

Table V The iridocorneal endothelial syndrome $e^{36,367,368}$

\begin{tabular}{ll}
\hline Essential iris atrophy & $\begin{array}{l}\text { Broad iris synechiae } \\
\text { Distortion of pupil } \\
\text { Ectropion uvea } \\
\text { Iris holes } \\
\text { Sphincter pupillae } \\
\text { preserved } \\
\text { Corneal oedema over } \\
\text { synechiae }\end{array}$ \\
Chandler's syndrome & $\begin{array}{l}\text { Few iris features } \\
\text { Diffuse corneal oedema } \\
\text { Secondary glaucoma }\end{array}$ \\
& $\begin{array}{l}\text { Pigmented iris nodules in } \\
\text { addition to the above } \\
\text { features }\end{array}$ \\
\hline
\end{tabular}

ities of the endothelium in the contralateral eye, iris transillumination defects and a reduction in the outflow facility all suggest that this is a bilateral disease with asymmetrical involvement. ${ }^{372,373,374}$

Specular microscopic examination has demonstrated that there are two cell populations: a unique 'ICE cell' that has a very irregular shape and reversed cell highlights and cells of normal appearance that may be at either a greater or lesser density than the cells of the unaffected eye. ${ }^{373,375,376}$ There are marked regional variations, with cells of normal configuration and areas of gross pleomorphism. ${ }^{377,378,379,380}$ When first examined, corneal involvement can be incomplete, in which case there is a sharp interface between the two populations of cells. Dystrophic cells can gradually replace the normal cells, an event that is frequently followed by an increase in intraocular pressure.

At histological examination, the striking feature is the wide variety of endothelial change, filopodia formation, multilayering of cells and localised cell necrosis. A collagenous layer forms posterior to normal Descemet's membrane and beneath ectopic endothelium on the iris surface - the 'glass membrane' seen by light microscopy. ${ }^{381}$ Iris nodules of modified melanocytes can protrude through gaps in this ectopic membrane. ${ }^{382}$ Features suggestive of epithelialisation of the posterior corneal surface have been demonstrated in cases of Chandler's syndrome ${ }^{383,384}$ and, while the original diagnosis of ICE syndrome must be carefully considered, the increased expression of cytokeratins (epithelioid metaplasia) suggests a link between the ICE syndrome and PPMD. ${ }^{385}$

The features of the ICE syndrome result from degeneration of the endothelial cells on the posterior cornea. There is an associated, but paradoxical, proliferation of the remaining cells onto the iris, ${ }^{364,385}$ although mitotic division is rarely observed. ${ }^{379,380} \mathrm{~A}$ reduction in outflow facility is presumably the result of the growth of endothelial cells onto the trabecular meshwork. ${ }^{386,387}$ Contraction of the collagen formed beneath the ectopic endothelium then produces peripheral anterior synechiae, an ectopic pupil, and traction tears of the iris. Evidence for vascular occlusion 


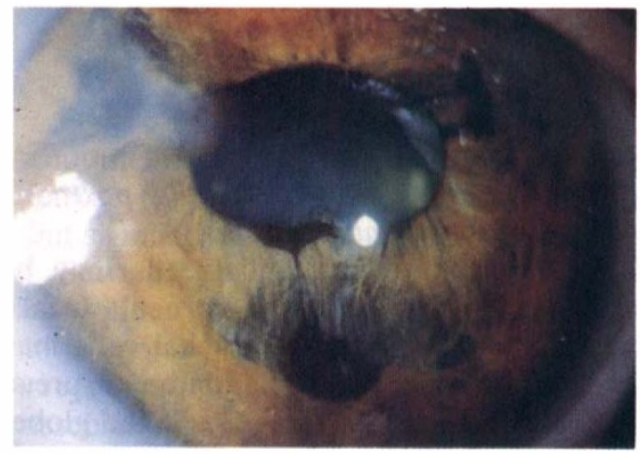

Fig. 13. ICE syndrome. (a) Clinical photograph demonstrating areas of corneal clouding, broad anterior synechiae, and an iris hole. Chandler's syndrome presenting as diffuse corneal oedema in an otherwise asymptomatic eye. (b) On specular microscopy, the endothelial mosaic is irregular and there are several ICE cells with reversed highlights (arrows). (c) A line of demarkation may be seen in cases of incomplete endothelial involvement.

Fig. 13a.

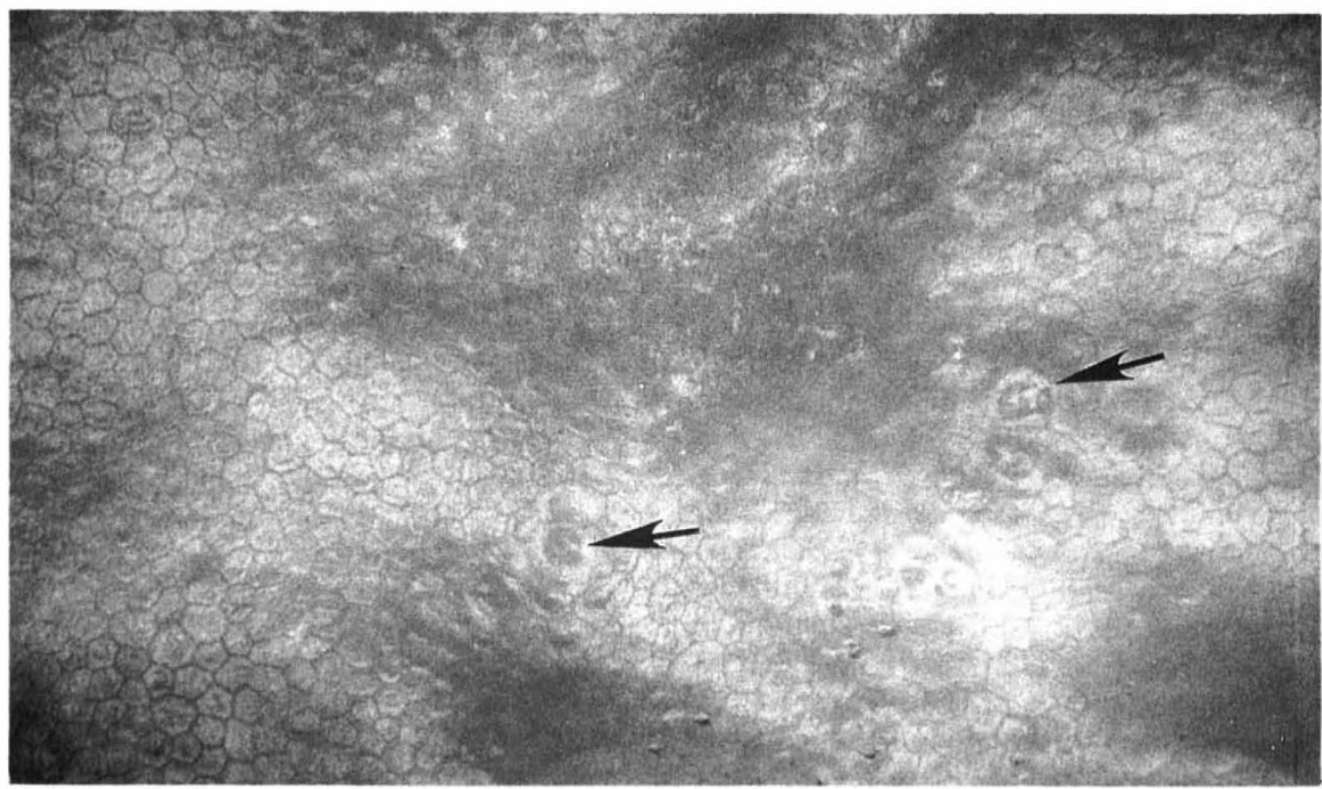

Fig. 13h.

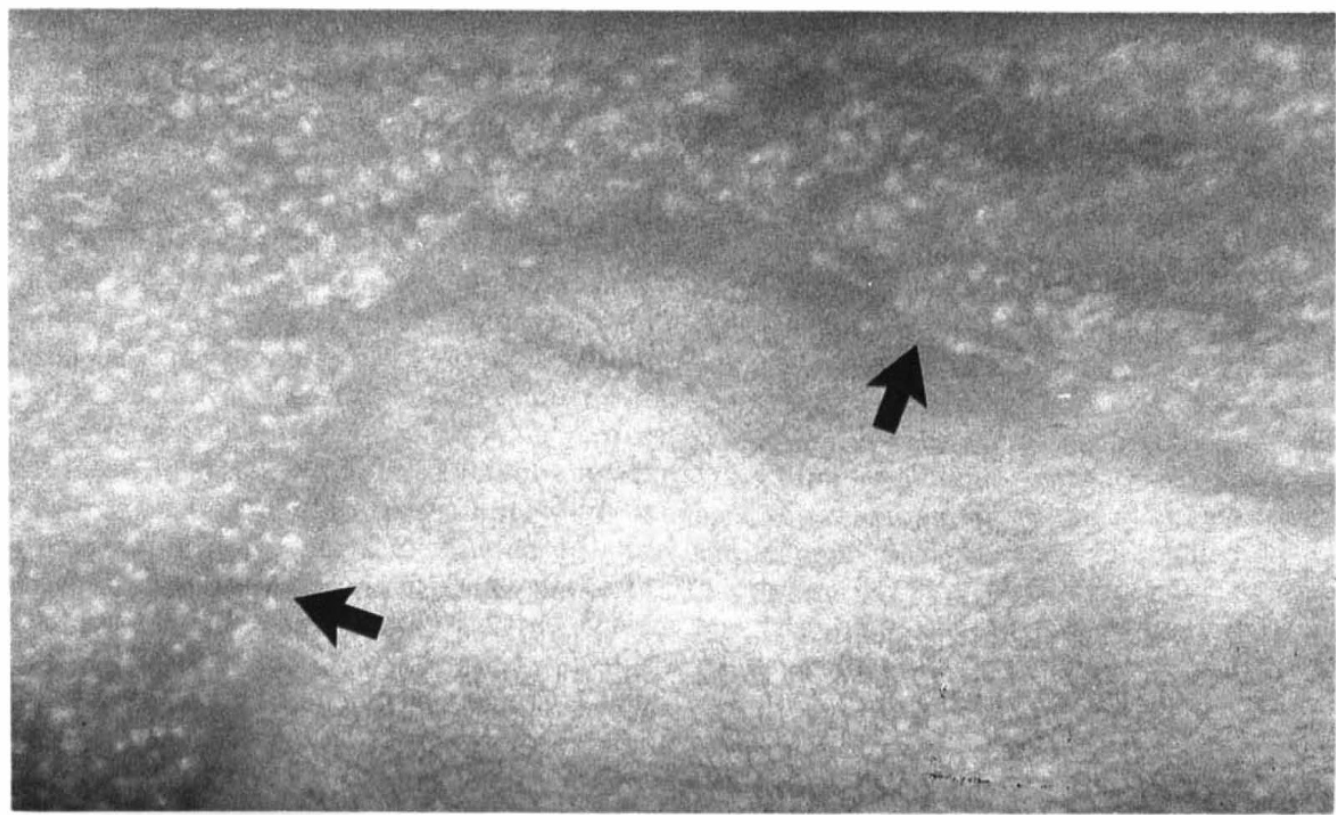

Fig. 13c. 
producing the iris holes in this disease is conflicting; some studies have failed to demonstrate any occlusion ${ }^{372}$ while others have demonstrated widespread vascular change. ${ }^{388,389}$ It is tempting to postulate that differences in the relative contribution of the three basic features of this condition-endothelial cell loss, endothelial migration and the deposition of an ectopic Descemet's membrane-could be reflected as three clinical variants. ${ }^{390}$ The presence of normal Descemet's tissue beneath a posterior collagenous layer points to a post-natal onset of disease ${ }^{379}$ interpreted as either the delayed expression of abnormal neural crest development or an acquired inflammatory lesion.

Most patients with ICE syndrome maintain excellent vision and require only periodic review. The breakdown of the syndrome into three groups is of little clinical significance, particularly as patients may progress between groups. ${ }^{369}$ However, it is important to make the distinction from other causes of iris tumour, for example iris melanoma, and to recognise a tendency to develop a raised intraocular pressure. In the presence of glaucoma, management should initially be directed toward control of aqueous production by medical means, but filtering surgery is eventually required in about $50 \%$ of cases. ${ }^{391}$ Subsequent proliferation of endothelium into the filtering bleb may cause failure of some operations, but surgery can be repeated. Symptoms of early corneal oedema may be controlled by hypertonic drops or a soft contact lens, but penetrating keratoplasty, following the control of raised intraocular pressure, may be required if corneal oedema produces significant visual loss or ocular discomfort. There are no histological reports of recurrence of the primary disease in the donor corneal button. ${ }^{392,393}$

\section{Acquired Disorders-the Endothelial Response to External Influences}

The corneal endothelium has a limited repertoire of responses to challenge. Sub-lethal injury results in minor pleomorphic changes in the cellular array, more damaging injury may produce metaplasia, but cell loss is the most common response to trauma. Surgical intervention is the most common noxious stimulus experienced by the cornea.

\section{Surgical Injuries}

\section{Epithelial downgrowth and other post-} surgical retrocorneal membranes

Cells other than endothelial cells may be seeded onto the posterior corneal surface where they may grow. Epithelial cells may spread after traumatic implantation or spread through a gap in the integrity of the globe. Study of organ cultured corneas suggests that epithelium will not overgrow healthy endothelium, ${ }^{394,395}$ and progressive endothelial disease seems to be a prerequisite for clinical disease. ${ }^{396,397,398,399}$ However, in an inverted keratoplasty model of epithelial downgrowth developed in the cat, epithelial cells grow across residual endothelium onto the iris. ${ }^{400}$ Iris pigment epithelial cells, iris stromal melanocytes or pigment-containing macrophages can also be seeded onto the back of the cornea, where they develop into pigmented retrocorneal membranes. ${ }^{401,402}$ Melanocytes in this location may cover a large area, but such membranes do not invariably induce corneal oedema. It has been suggested that, as they are of neural crest origin, they are able to develop a pumping facility. ${ }^{403,404}$ Alternatively, functioning endothelial cells may survive beneath the melanocytic layer. These hypotheses require further study.

\section{Post-Surgical Endothelial Cell Loss}

Loss of some endothelial cells after intraocular surgery is inevitable. This subject has been discussed in detail in a previous section.

\section{Non-Surgical Injuries to the Endothelium 1. Concussive injuries}

Breaks in Descemet's membrane can produce endothelial damage after forceps injuries, in congenital glaucoma and keratoconus, and in high myopia. ${ }^{405}$ The cell loss after a blunt injury is then exacerbated by an associated hyphaema, uveitis or raised intraocular pressure. ${ }^{406,407}$ A condition termed traumatic posterior annular keratopathy has been observed to follow the impact of high velocity particles on the superficial stroma, most frequently after powder flash or sand blasting injuries: as particles strike the cornea they generate a shock wave that passes backward from the point of impact producing a ring of vacuolated 
endothelial cells with an adherent plaque of leukocytes and fibrin. This usually heals without significant endothelial cell loss. ${ }^{408}$

Secondary proliferation of the endothelium can follow blunt ocular injury, especially if the blow is of sufficient force to produce an angle recession $;^{409,410,411}$ less frequently it is seen in association with rubeosis iridis. ${ }^{412}$ There is a reduction in the density of the remaining endothelial cells and obstruction of the anterior chamber angle. ${ }^{295}$

\section{Hypoxia}

Transient bleb-like structures in the specular image develop after overnight lid closure, ${ }^{413}$ or within minutes of placing a low oxygen transmission contact lens onto the unadapted eye. ${ }^{414}$ These changes, and a co-existent increase in corneal thickness, could be the direct result of endothelial hypoxia, ${ }^{415}$ but more probably are the result of epithelial hypoxia, the retention of $\mathrm{CO}_{2}$ and the accumulation of lactic acid producing an osmotic imbalance. ${ }^{416,417}$ Although the acute changes persist for only one to two hours after removal of the contact lens, a reduced regularity of the endothelial matrix has been documented after the long-term use of both daily wear and extended wear contact lenses wearers. ${ }^{418,419,420,421,422,423}$ Although there is no convincing evidence of a resulting abnormality of endothelial function, PMMA contact lenses may increase endothelial cells loss if worn after penetrating keratoplasty. ${ }^{424}$

Anterior segment hypoxia could contribute directly to the endothelial cell loss and corneal oedema that can follow temporal arteritis, anterior segment necrosis, herpes zoster ophthalmicus and acute closed-angle glaucoma. ${ }^{425}$ This is supported by experimental observation in which ablation of the long posterior ciliary arteries in the rabbit produces a sharp drop in the anterior chamber oxygen tension and glucose concentration, which is followed by corneal oedema. ${ }^{426}$

\section{Raised intraocular pressure}

In the presence of an intact endothelial layer, an increase in intraocular pressure (IOP) will initially produce corneal thinning; corneal oedema is produced only if the endothelial pump is overwhelmed. ${ }^{427,428,429}$ The endothelium can adapt to a gradual increase in IOP,${ }^{430,431}$ but rapid rises in IOP result in endothelial cell damage. The cell loss after an acute angle-closure attack is roughly proportional to the duration of stromal swelling during the attack; a mean cell loss of $23 \%$ has been reported. ${ }^{432,433}$ In contrast, cell loss has not been consistently demonstrated in primary open angle glaucoma or pigmentary dispersion glaucoma, ${ }^{434}$ although there appears to be a tendency for cell loss in pseudexfoliative glaucoma. ${ }^{435,436,437}$ In other situations it is difficult to isolate the effect of increased IOP; for example, a $10 \%$ cell loss has been reported following glaucomatico-cyclitic crises, ${ }^{435}$ but this may be due in part to associated inflammation. A similarly complex pattern occurs in herpes zoster ophthalmicus, where there can be a considerable cell loss but the relative contributions of viral endotheliitis, inflammation, and ischaemia are not known. ${ }^{438}$

\section{Electromagnetic radiation}

The cornea is effectively opaque to radiation of less than $290 \mathrm{~nm}$, but prolonged exposure to broad band UV-B has been documented to induce endothelial swelling, desquamation and the development of microvilli. ${ }^{439,440}$ Whether this is a direct effect upon the endothelium or subsequent to inflammation induced by epithelial damage is unclear. Other wavelengths have no demonstrated effect.

\section{Effects of Ocular Disease}

\section{Uveitis}

Leukocytes that enter the anterior chamber can migrate between and beneath endothelial cells where they appear as pseudoguttata on the specular image. ${ }^{441,442}$ Following mild uveitis, these changes are reversible, but marked cell loss can follow severe uveitis, especially beneath mutton fat keratin precipitates. ${ }^{443}$ This may be the result of mononuclear cells, which have been observed to penetrate apical junctions in experimental uveitis and to dislodge endothelial cells into the anterior chamber. ${ }^{444}$ Polymorphonuclear leukocytes in the anterior chamber can also produce toxic endothelial damage and oedema. ${ }^{44}$ Similar 
changes have been produced by the hydrolytic enzyme cathepsin and by neutral proteases that digest cell surface proteins and glycoproteins. ${ }^{446}$

\section{Viral infection}

The herpes simplex virus can be cultured from the stroma of a percentage of patients with disciform keratitis and it is probable that the virus can invade endothelial cells directly. The resulting endotheliitis and secondary attack by immunocompetent leukocytes produces pseudoguttata and oedema of the overlying stromal and epithelium. ${ }^{447}$

A bilateral and symmetric stromal oedema that moves centrally behind a line of keratic precipitates has been termed presumed autoimmune endotheliopathy. ${ }^{448}$ Although it responds readily to topical steroid, the aetiology of this rare condition remains an enigma. Similar, but unilateral, cases that do not respond to steroid have been reported. ${ }^{449}$ The anterior chamber in these cases contains macrophages and lymphocytes, but attempts to isolate viruses have been unsuccessful.

Endothelial cells may also be involved by disease processes that have their primary effect upon other corneal layers. For example, there may be endothelial deposition of acid mucopolysaccharide in macular corneal dystrophy. ${ }^{450}$

\section{Systemic Metabolic Disease \\ Diabetes}

Human diabetic corneal endothelium appears to have a normal cell density but it is more susceptible to stress than normal endothelium and stromal oedema following surgical procedures may be slow to resolve. ${ }^{451}$ The endothelium of both juvenile and adult onset diabetic patients is often abnormal on morphometric analysis ${ }^{452}$ and has a higher permeability to fluorescein. ${ }^{453} \mathrm{~A}$ failure to demonstrate an increase in the thickness of the basement membrane of the endothelium (Descemet's membrane) comparable to increases demonstrated elsewhere in diabetics is thought to reflect the low turn-over of these cells. ${ }^{454,455}$

\section{Conclusion}

That so much attention has been directed to studies of the corneal endothelium by laboratory-based and clinical scientists is an indication of the importance and complexity of disorders affecting this seemingly simple monolayer of cells. The pathway to a complete understanding of the disorders of the endothelium extends before us. Much has been learned in the last two decades, and is the subject of this review, however much remains to be learned in the years to come. With the advances in basic science, particularly molecular biology, transplantation and immunology, powerful tools have been developed which are being used to increase an understanding of the biology of the corneal endothelial cell. Progress in this area of research is accelerating and the prospects of conquering the common disorders of the endothelium in the forseeable future are very real.

We would like to thank Dr Emil Sherrard and Dr Alison McCartney of the Institute of Ophthalmology, London, and Dr Keryn Williams of the Flinders Medical Centre, Adelaide, for reviewing various aspects of the manuscript, Dr Nick McKecknie for providing Fig. 5, Emil Sherrard for Fig. 13c and Dr Nan Carroll of the Royal Victorian Eye and Ear Hospital, Melbourne, for providing scanning electron micrographs.

\section{References}

${ }^{1}$ Ozanics V and Jakobiec FA: Prenatal Development of the eye and its Adnexa. In Duane TD, Jaeger EA eds. Biomedical Foundations of Ophthalmology. Philadelphia: Harper \& Row 1982: Vol 1, Chapter 2.

${ }^{2}$ Weston JA: The migration and differentiation of neural crest cells. Adv Morph 1970, 8: 41-114.

${ }^{3}$ Noden DM: An analysis of the migratory behaviour of avian cephalic neural crest çells. Dev Biol 1975, 42: 106-30.

${ }^{4}$ Le Lievre CS and Le Douarin NM: Mesenchymal derivatives of the neural crest: analysis of chimeric quail and chick embryos. J Embryol Exp Morph 1975, 34: 125-54.

${ }^{5}$ Johnson MC, Noden DM, Hazelton RD, et al: Origins of avian ocular and periocular tissues. Exp Eye Res 1979, 29: $27-43$.

${ }^{6}$ Noden DM: Periocular mesenchyme: neural crest and mesodermal interactions. In Duane TD, Jaeger EA eds. Biomedical Foundations of Ophthalmology. Philadelphia: Harper \& Row 1982: Vol 1, Chapter 3.

${ }^{7}$ Johnston MC: A radioautographic study of the migration and fate of cranial neural crest cells in the chick embryo. Anat Rec 1966, 156: 143-56.

${ }^{8}$ Le Douarin NM: Charactéristiques ultrastructurales du noyau interphasique chez la caille et chez le poulet et utilisation de céllules de caille 'marquers biologiques' en embryologie expérimentale. Ann Embryol Morphol 1971, 4: 125-35.

${ }^{9}$ Duke-Elder $S$ and Cook C: Normal and abnormal development. In Duke-Elder S ed. System of ophthalmology St Louis: CV Mosby 1963: Vol 3, Part 1, Embryology. 
${ }^{10}$ Schook P: Cell action and interaction during ocular morphogenesis. In Duane TD, Jaeger EA eds. Biomedical Foundations of Ophthalmology. Philadelphia: Harper \& Row 1982: Vol 1, Chapter 5.

${ }^{11}$ Hay ED: Development of the vertebrate cornea. Int Rev Cytol 1980, 63: 263-322.

${ }^{12}$ Ozanics V, Rayborn M, Sagun D: Observations of the morphology of the developing primate cornea. J Morphol 1977, 153: 263-98.

${ }^{13}$ Mann I: The development of the human eye. 5th ed. New York. Grune \& Stratton Inc, 1964.

${ }^{14}$ Kurkinen M, Alitalo K, Vaheri A, et al. Fibronectin in the development of the embryonic chick eye. Dev Biol 1979, 69: 589-600.

${ }^{15}$ Meier S: Initiation of corneal differentiation prior to corneal-lens association. Cell Tiss Res 1977, 184: 255-68.

${ }^{16}$ Hansson H-A and Jerndal T: Scanning electron microscopic studies of the development of the iridocorneal angle in human eyes. Invest Ophthalmol Vis Sci 1971, 10: $252-65$.

${ }^{17}$ Van Buskirk EM: Clinical implication of iridocorneal angle development. Ophthalmology 1981, 88: 361-7.

${ }^{18}$ Noden DM: The control of avian cephalic neural crest cytodifferentiation. Dev Biol 1978, 67: 296-312.

${ }^{19}$ Coulombre AJ: Regulation of ocular morphogenesis. Invest Ophthalmol Vis Sci 1969, 8: 25-31.

${ }^{20}$ Weston JA: The regulation of normal and abnormal neural crest development. Adv Neurol 1981, 29: 77-95.

${ }^{21}$ Genis-Galves JM: Role of the lens in the morphogenesis of the iris and cornea. Nature 1966, 210: 209-10.

${ }^{22}$ Nelson GA and Revel J-P: Scanning electron microscopic study of cell movements in the corneal endothelium of the avian embryo. Dev Biol 1975, 42: 315-37.

${ }^{23}$ Bard JBL, Hay ED, Meller SM: Formation of the endothelium of the avian cornea: a study of cell movement in vivo. Dev Biol 1975, 42: 334-61.

${ }^{24}$ Zinn KM: Changes in corneal ultrastructure resulting from early lens removal in the developing chick embryo. Invest Ophthalmol Vis Sci 1970, 9: 165-82.

${ }^{25}$ Wulle KG: Electron microscopy of the fetal development of the corneal endothelium and Descemet's membrane of the human eye. Invest Ophthalmol Vis Sci 1972, 11: 897-904.

${ }^{26}$ Coulombre AJ and Coulombre JL: Corneal development III. The role of the thyroid in dehydration and the development of transparency. Exp Eye Res 1964, 3: 105-14.

${ }^{27}$ Masterson E, Edelhauser HF, Van Horn DL: Role of thyroid hormone in the development of the chick corneal endothelium and epithelium. Invest Ophthalmol Vis Sci 1977, 16: 105-15.

${ }^{28}$ Wulle KG, Ruprecht KW, Windrath LC: Electron microscopy of the development of the cell junctions in the embryonic and fetal human corneal endothelium. Invest Ophthalmol Vis Sci 1974, 13: 923-34.

${ }^{29}$ Waring GO, Laibson PR, Rodrigues MM: Clinical and pathological alterations of Descemet's membrane with emphasis on endothelial metaplasia. Surv Ophthalmol 1974, 18: 325-68.

${ }^{30}$ Johnson DH, Bourne WM, Campbell RJ: The ultrastructure of Descemet's membrane I. Arch Ophthalmol 1982, 100: 1942-7.

${ }^{31}$ Laing RA, Sandstrom MM, Berrospi AR, et al: Changes in the corneal endothelium as a function of age. Exp Eye Res 1976, 22: 587-94.

${ }^{32}$ Bourne WM and Kaufman HE: Specular microscopy of human corneal endothelium in vivo. Am J Ophthalmol 1976, 81: 319-23.

${ }^{33}$ Blatt HL: Endothelial cell density in relation to morphology. Invest Ophthalmol Vis Sci 1979, 18: 856-9.

${ }^{34}$ Hiles DA, Biglan AW, Fetherholf EC: Central corneal endothelial cell counts in children. Am Intra-Ocular Implant Soc J 1979, 5: 292-300.
${ }^{35}$ Speedwell L, Novakovic P, Sherrard ES, Taylor DS: The infant corneal endothelium. Arch Ophthalmol 1988, 106: $771-5$.

${ }^{36}$ Bahn CF, Glassman RM, MacCallum DK, et al: Postnatal development of corneal endothelium. Invest Ophthalmol Vis Sci 1986, 27: 44-51.

${ }^{37}$ Sturrock GD, Sherrard ES, Rice NSC: Specular microscopy of the corneal endothelium. Br J Ophthalmol 1978, 62: 809-14.

${ }^{38}$ Hoffer KJ and Kraff MC: Normal endothelial cell count range. Ophthalmology 1980, 87: 861-5.

${ }^{39}$ Wilson RS and Roper-Hall MJ: Effect of age on the endothelial cell count in the normal eye. Br J Ophthalmol 1982, 66: 513-15.

${ }^{40}$ Murphy C, Alvarado J, Juster R, et al: Prenatal and postnatal cellularity of the human corneal endothelium. Inv Ophthalmol Vis Sci 1984, 25: 312-22.

${ }^{41}$ Laule A, Cable MK, Hoffman CE, et al: Endothelial cell population changes of human cornea during life. Arch Ophthalmol 1978, 96: 2031-5.

${ }^{42}$ Baroody RA, Bito LZ, Derousseau CJ, Kaufman PL: Ocular development of ageing I. Corneal endothelial changes in cats and in free-ranging and caged rhesus monkeys. Exp Eye Res 1987, 45: 607-22.

${ }^{43}$ Fitch KL, Nadakavukaren MJ, Richardson A: Agerelated changes in the corneal endothelium in the rat. Exp Gerontol 1982, 17: 179-83.

${ }^{44}$ MacCallum DK, Bahn CF, Lillie JH, et al: Evidence for corneal endothelial cells hypertrophy during postnatal growth of the cat cornea. Invest Ophthalmol Vis Sci 1983, 24: 247-50.

${ }^{45}$ Gwin RM, Lerner I, Warren JK, et al: Decrease in canine corneal endothelial cell density and increase in corneal thickness as functions of age. Invest Ophthalmol Vis Sci 1982, 22: 267-71.

${ }^{46} \mathrm{Oh}$ JO: Changes with age in the cornea of normal rabbits. Acta Ophthalmol 1963, 41: 568-73.

${ }^{47}$ Hogan MJ, Alvarado JA, Weddell JS: In Histology of the human eye. Philadelphia: W. B. Saunders 1971: 102-3.

${ }^{48}$ Gallagher B: Primary cilia of the corneal endothelium. Am J Anat 1980, 159: 475-84.

${ }^{49}$ Svedbergh B and Bill A: Scanning electron microscopic studies of the corneal endothelium in man and monkeys. Acta Ophthalmol 1972, 50: 321-36.

${ }^{50}$ Kreutziger GO: Lateral membrane morphology and gap junction structure in rabbit corneal endothelium. Exp Eye Res 1976, 23: 285-93.

${ }^{51}$ Hirsch M, Renard G, Faure JP, et al: Study of the ultrastructure of the rabbit corneal endothelium by the freeze-fracture technique: apical and lateral junctions. Exp Eye Res 1977, 25: 277-88.

${ }^{52}$ Ringvold A, Davanger M, Olsen EG: On the spatial organisation of the corneal endothelium. Acta Ophthalmol 1984, 62: 911-18.

${ }^{53}$ Waring GO, Laibson PRT, Rodrigues M: Clinical and pathological alterations of Descemet's membrane: with emphasis on endothelial metaplasia. Surv Ophthalmol 1974, 18: 325-68.

${ }^{54}$ Kampik A, Patrinely JR, Green RW: Morphologic and clinical features of retrocorneal melanin pigmentation and pigmented pupillary membrane. Surv Ophthalmol 1982, 27: 161-80.

${ }^{55}$ Gordon SR, Essner E, Rothstein $\mathrm{H}$ : In situ demonstration of action in normal and injured ocular tissues using 7-nitro-benz-2-oxa 1, 3 diazole phallacidin. Cell Motil 1982, 4: 343-54.

${ }^{56}$ Gospodarowicz D, Greenburg G, Vlodavsky L, et al: The identification and localisation of fibronectin in cultured corneal endothelial cells. Exp Eye Res 1979, 29: 485-509.

${ }^{57}$ Fehrenbacher L, Gospodarowicz D, Shuman MA: Synthesis of plasminogen activator by bovine corneal endothelial cells. Exp Eye Res 1979, 29: 219-28. 
${ }^{58}$ Singer SJ and Nicholson GL: The fluid mosaic model of the structure of cell membranes. Science 1972, 175: 720-31.

${ }^{59}$ Mishima S: Corneal thickness. Surv Ophthalmol 1968, 13: 57-96.

${ }^{60}$ Hedbys BO, Mishima S, Maurice DM: The inhibition pressure of the corneal stroma. Exp Eye Res 1963, 2: 99-111.

${ }^{61}$ Harris JE and Nordquist LT: The hydration of the cornea. Am J Ophthalmol 1955, 40: 100-10.

${ }^{62}$ Weissman BA, Fatt I, Rasson J: Diffusion of oxygen in human corneas in vivo. Invest Ophthalmol vis Sci 1981, 20: $123-5$.

${ }^{63}$ Mishima S and Maurice DM: The effect of normal evaporation upon the eye. Exp Eye Res 1961, 1: 46-52.

${ }^{64}$ Mayes KR and Hodson S: Some effects of hydrostatic pressure on corneal hydration during specular microscopy. Exp Eye Res 1978, 26: 141-5.

${ }^{65}$ Hodson S and Miller F: The bicarbonate ion pump in the endothelium which regulates the hydration of the rabbit cornea. J Physiol 1976, 263: 563-77.

${ }^{66}$ Hodson S, Wigham C, Williams L, et al: Observations on the human cornea in vitro. Exp Eye Res 1981, 32: 353-60.

${ }^{67}$ Hull DS, Green K, Boyd M, et al: Corneal endothelium bicarbonate transport and the effect of carbonic anhydrase inhibitors on the permeability and fluxes and corneal thickness. Invest Ophthalmol Vis Sci 1977, 16: 883-92.

${ }^{68} \mathrm{Lim} \mathrm{JJ}$ : Effects of bicarbonate on the potential difference across the rabbit corneal endothelium. Curr Eye Res 1982, 2: 529-35.

${ }^{69}$ Hodson S: Evidence for a bicarbonate-dependent sodium pump in corneal endothelium. Exp Eye Res 1971, 11: 20-9.

${ }^{70}$ Dikstein S and Maurice DM: The metabolic basis to the fluid pump in the cornea. J Physiol 1972, 221: 29-41.

${ }^{71}$ Fischbarg J and Lim J J: Role of cations, anions and carbonic anhydrase in fluid transport across rabbit corneal endothelium. J Physiol 1974, 241: 647-75.

${ }^{72}$ Mayes KR and Hodson S: Local osmotic coupling to the active transendothelial bicarbonate flux in the rabbit cornea. Biochim Biophys Acta 1978, 514: 286-93.

${ }^{73}$ Fischbarg J, Lim JJ, Bourguet J: Adenosine stimulation of fluid transport across rabbit endothelium. $\mathrm{J} \mathrm{Mem}$ Biol 1977, 35: 95-112.

${ }^{74}$ Neuwirth O and Dickstein S: The effect of cyclic AMP on the rabbit corneal endothelial fluid pump. Curr Eye Res 1982, 8: 565-7.

${ }^{75}$ Riley MV: Anion-sensitive ATPase in rabbit corneal endothelium and its relation to corneal hydration. Exp Eye Res 1977, 25: 483-94.

${ }^{76}$ Whikhart DR and Soppet DR: Activities of transport enzymes located in the plasma membranes of corneal endothelial cells. Invest Ophthalmol Vis Sci 1981, 21: $819-25$

${ }^{77}$ Trenberth SM and Mishima S: The effect of ouabain on the rabbit corneal endothelium. Invest Ophthalmol Vis Sci 1968, 7: 44-52.

${ }^{78}$ Geroski DH, Kies JC, Edelhauser HF: The effects of ouabain on endothelial function in human and rabbit cornea. Curr Eye Res 1984, 3: 331-8.

${ }^{79}$ Fischbarg J, Hernandez J, Liebovitch LS, et al: The mechanism of fluid and electrolyte transport across corneal endothelium. Curr Eye Res 1985, 4: 351-60.

${ }^{80}$ Liebovitch LS and Fischbarg J: Effects of inhibitors of passive $\mathrm{Na}^{+}$and $\mathrm{HCO}^{-}$fluxes on electrical potential and fluid transport across rabbit corneal endothelium. Curr Eye Res 1982, 2: 183-6.

${ }^{81}$ Huff JW and Green K: Characterisation of bicarbonate, sodium and chloride fluxes in the rabbit corneal endothelium. Exp Eye Res 1983, 36: 607-16.
${ }^{82}$ Kaye GI and Tice LW: Studies on the cornea. V. Electron microscopic localisation of adenosine triphosphatase activity in the rabbit cornea in relation to transport. Invest Ophthalmol Vis Sci 1966, 5: 22-30.

${ }^{83}$ Lyslo A, Kvernes S, Garlid K, et al: Ionic transport across corneal endothelium. Acta Ophthalmol 1985, 63: $116-25$.

${ }^{84}$ Geroski DH, Matsuda M, Yee RW, Edelhauser HF: Pump function of the human corneal endothelium. Ophthalmology 1985, 92: 759-63.

${ }^{85}$ McCartney MD, Wood TO, McLaughlin BJ: Immunohistochemical localisation of ATPase in human dysfunctional corneal endothelium. Curr Eye Res 1987, 12: 1479-86.

${ }^{86}$ Sasaki Y, Turberville AW, Wood TO, McLaughlin BJ: Freeze fracture study of human corneal endothelial dysfunction. Invest Ophthalmol Vis Sci 1986, 27: 480-5.

${ }^{87}$ Mishima S and Hedbys BO: The permeability of the corneal epithelium and endothelium to water. Exp Eye Res 1967, 6: 10-32.

${ }^{88}$ Kaye GI, Hoefle FB, Donn A: Studies on the cornea. VIII. Reversibility of the effects of in vitro perfusion of the rabbit corneal endothelium with calcium-free medium. Invest Ophthalmol Vis Sci 1973, 12: 98-113.

${ }^{89}$ Kaye GI, Mishima S, Cole JD, etal: Studies on the cornea. VII. Effects of perfusion with a $\mathrm{Ca}^{++}$free medium on the corneal endothelium. Invest Ophthalmol Vis Sci 1968, 7: 53-66.

${ }^{90}$ Edelhauser HF, Van Horn DL, Miller P, et al: Effect of thiol-oxidation of glutathione with diamide on corneal endothelium. J Cell Biol 1976, 68: 567-78.

${ }^{91}$ Mishima S: Clinical investigations of the corneal endothelium. XXXVIII Edward Jackson memorial lecture. Am J Ophthalmol 1982, 93: 1-29.

${ }^{92}$ Vogt A: Die sichtbarkeit des lebenden hornhautendothels im lichtbueschel der gullstrandschen spaltlampe. Klin Monatsbl Augenheilkd 1919, 63: 233-4.

${ }^{93}$ Laing RA, Sandstrom MM, Leibowitz HM: Clinical specular microscopy. I. Optical Principles. Arch Ophthalmol 1979, 97: 1714-19.

${ }^{94}$ Sherrard ES and Buckley RJ: Clinical specular microscopy of the corneal endothelium. Trans Ophthalmol Soc UK 1981, 101: 156-62.

${ }^{95}$ Sherrard ES and Buckley RJ: Endothelial wrinkling. In Trevor-Roper P ed. Trans VI Cong Europ Soc Ophthalmol. London: Roy Soc Med 1980: 69

${ }^{96}$ Waring GO, Bourne WB, Edelhauser HF, et al: The corneal endothelium. Ophthalmology 1982, 89: 531-90.

${ }^{97}$ Rao GN, Lolhman LE, Aquavella JV: Cell size-cell relationships in corneal endothelium. Invest Ophthalmol Vis Sci 1982, 22: 271-4.

${ }^{98}$ Matsuda M, Suda T, Manabe R: Serial alterations in endothelial cell shape and pattern after intraocular surgery. Am J Ophthalmol 1984, 98: 313-19.

${ }^{99}$ Hirst LW: Quantitative analysis of wide-field endothelial specular photomicrographs. Am J Ophthalmol 1984 97: 488-95

${ }^{100}$ Holladay JT, Bishop JE, Prager TC: Quantitative endothelial biomicroscopy. Ophthalmic Surg 1983, 14: $33-40$.

${ }^{101}$ Hedbys BO and Mishima S: The thickness-hydration relationship of the cornea. Exp Eye Res 1966, 5: 221-8.

${ }^{102}$ Wood WJ and Maumenee AE: Corneal thickness after cataract surgery. Trans Am Acad Ophthalmol Otolaryngol 1975, 79: 631-4.

${ }^{103}$ Olsen T: Corneal thickness and endothelial damage after intracapsular cataract extraction. Acta Ophthalmol 1980, 58: 424-33.

${ }^{104}$ Cheng H, Bates AK, Wood L, McPherson K: Positive correlation of endothelial thickness and endothelial cell loss. Arch Ophthalmol 1988, 106: 920-2.

${ }^{105}$ Mandell RB, Polse KA, Fatt I: Corneal swelling caused by contact lens wear. Arch Ophthalmol 1970, 83: 3-9. 
${ }^{106}$ Klyce SD: Stromal lactate accumulation can account for corneal oedema osmotically following epithelial hypoxia in the rabbit. J Physiol 1981, 321: 49-64.

${ }^{107}$ Weissman BA, Fatt I, Horn B: Reversal of anoxic corneal swelling by breathing oxygen. Invest Ophthalmol Vis Sci 1982, 22: 124-7.

${ }^{108}$ Azen SP, Burg KA, Smith RE et al: A comparison of three methods for the measurement of corneal thickness. Invest Ophthalmol Vis Sci 1979, 18: 535-8.

${ }^{109} \mathrm{O}$ 'Neal MR and Polse KA: In vivo assessment of mechanisms controlling corneal hydration. Invest Ophthalmol Vis Sci 1985, 26: 849-56.

${ }^{110}$ O'Neal MR and Polse KA: Decreased endothelial pump function with ageing. Invest Ophthalmol Vis Sci 1986, 27: 457-63.

${ }^{111}$ Chaston $\mathrm{J}$ and Fatt $\mathrm{I}$ : Corneal oedema in phakic and aphakic eyes. Curr Eye Res 1981, 1: 119-21.

${ }^{112}$ Holden BA, Polse KA, Fonn D, et al: Effects of cataract surgery on corneal function. Invest Ophthalmol Vis Sci 1982, 22: 343-50.

${ }^{113}$ Coakes RL and Brubaker RF: Method of measuring aqueous humour flow and corneal endothelial permeability using a fluorophotometry nomogram. Invest Ophthalmol Vis Sci 1979, 18: 288-302.

${ }^{114}$ Bourne WM, Nagataki S, Brubaker RF: The permeability of the corneal endothelium to fluorescein in the normal human eye. Curr Eye Res 1984, 3: 509-13.

${ }^{115}$ Burns RR, Bourne WM, Brubaker RF: Endothelial function in patients with cornea guttata. Invest Ophthalmol Vis Sci 1981, 20: 77-85.

${ }^{116}$ Bourne WM and Brubaker RF: Decreased endothelial permeability in the iridocorneal endothelial syndrome. Ophthalmology 1982, 89: 591-5.

${ }^{117}$ Sawa M, Araie M, Tanishima T: Permeability of the corneal endothelium to fluorescein-A follow-up of keratoplasty cases. Jpn J Ophthalmol 1982, 26: 326-37.

${ }^{118}$ Bourne WM and Brubaker RF: Decreased endothelial permeability in transplanted corneas. Am J Ophthalmol 1983, 96: 362-7.

${ }^{119}$ Tsuru T, Araie M, Sawa M, et al: A fluorophotometric study of the corneal graft. Graefes Arch Clin Exp Ophthalmol 1985, 22: 263-5.

${ }^{120}$ Ota Y: Endothelial permeability to fluorescein in corneal grafts and bullous keratopathy. J pn J Ophthalmol 1975, 19: $286-95$.

${ }^{121}$ Hoffer KJ: Corneal decompensation after endothelium cell count. Am J Ophthalmol 1979, 87: 252-3.

${ }^{122}$ Waring GO, Bourne WM, Edelhauser HF, et al: The corneal endothelium. Normal and pathologic structure and function. Ophthalmology 1982, 89: 531-90.

${ }^{123}$ Geroski DH, Matsuda M, Yee RW, et al: Pump function of human corneal endothelium. Ophthalmology 1985, 92: 759-63.

${ }^{124}$ Doughman DJ, Van Horn D, Rodman WP, et al: Human corneal endothelial layer repair during organ culture. Arch Ophthalmol 1976, 94: 1791-6.

${ }^{125}$ Sherrard ES: The corneal endothelium in vivo: its response to mild trauma. Exp Eye Res 1976, 27: 347-57.

${ }^{126}$ Koester CJ, Roberts CW, Donn A, et al: Wide field specular microscopy. Ophthalmology 1980, 87: 849-60.

${ }^{127}$ Rao GN, Shaw EL, Arthur E, et al: Morphologic appearance of the healing corneal endothelium. Arch Ophthalmol 1978, 96: 2027-30.

${ }^{128}$ Silverstein AM, Khodadoust AA, Prendergast RA: Desquamation of corneal endothelial cells. Invest Ophthalmol Vis Sci 1982, 22: 351-8.

${ }^{129}$ Binder RF and Binder HF: Regenerative processes in the endothelium of the cornea. Arch Ophthalmol 1957, 57: $11-13$.

${ }^{130} \mathrm{Chi} \mathrm{HH}$, Teng CC, Katzin HM: Healing process in the mechanical denudation of the corneal endothelium. Am J Ophthalmol 1960, 49: 693-703.
${ }^{131}$ Gipson IK: Cytoplasmic filaments: their role in motility and cell shape. Invest Ophthalmol Vis Sci 1977, 16: 1081-4.

${ }^{132}$ Gordon SR: The localisation of action in dividing corneal endothelial cells demonstrated with nitrobenzoxadiazole phalladin. Cell Tissue Res 1983, 229: 533-9.

${ }^{133}$ Fujino Y and Tanishima T: Actin in wound healing of rabbit corneal endothelium. Jap J Ophthalmol 1987, 31: 393-404.

${ }^{134}$ Goldminz D, Vlodavsky I, Johnsón LK, et al: Contact inhibition and the regulation of endocytosis in the corneal endothelium. Exp Eye Res 1979, 29: 331-51.

${ }^{135}$ Hirsch M, Renard G, Faure JP, e tal: Formation of intercellular spaces and junctions in regenerating rabbit corneal endothelium. Exp Eye Res 1976, 23: 385-97.

${ }^{136}$ Yano $\mathbf{M}$ and Tanishima T: Wound healing in rabbit corneal endothelium. Jpn J Ophthalmol 1980, 24: 297-309.

${ }^{137}$ Van Horn DL, Sendele DD, Seideman S, et al: Regenerative capacity of the corneal endothelium in rabbit and cat. Invest Ophthalmol Vis Sci 1977, 16: 597-613.

${ }^{138}$ Matsubara $\mathbf{M}$ and Tanishima T: Wound-healing of the corneal endothelium in the monkey: a morphometric study. Jpn J Ophthalmol 1982, 26: 264-73.

${ }^{139}$ Van Horn DL and Hyndiuk RA: Endothelial wound repair in primate cornea. Exp Eye Res 1975, 21: 113-24.

${ }^{140}$ Honda $\mathrm{H}$, Ogita Y, Higuchi S, et al: Cell movements in a living mammalian tissue: long-term observation of individual cells in wounded corneal endothelia of cats. $J$ Morphol 1982, 174: 25-39.

${ }^{141}$ Matsuda M, Sawa M, Edelhauser HF, et al: Cellular migration and morpholoy in corneal endothelial wound repair. Invest Ophthalmol Vis Sci 1985, 26: 443-9.

${ }^{142}$ Kaufman HE, Capella JA, Robbins JE: The human corneal endothelium. Am J Ophthalmol 1966, 61: 835-41.

${ }^{143}$ Rahi A HS and Robins E: Human corneal endothelial cell repair in health and disease. Trans Ophthalmol Soc UK 1981, 101: 30-4.

${ }^{144}$ Simonsen AH, Sorensen KE, Sperling S: Thymidine incorporation by human corneal endothelium during organ culture. Acta Ophthalmol 1981, 59: 110-18.

${ }^{145}$ Treffers WF: Corneal endothelial wound healing. (Thesis), Janssen/Print Nijmegan 1982.

${ }^{146}$ Laing RA, Neubauer L, Oak SS, Kayne HL, Leibowitz $\mathrm{M}$ : Evidence for mitosis in the adult corneal endothelium. Ophthalmology 1984, 91: 1129-34.

${ }^{147}$ Hoffer KJ: Vertical endothelial cell disparity. Am J Ophthalmol 1979, 87: 344-9.

${ }^{148}$ Galin MA, Lin LC, Fetherolf E, et al: Time analysis of corneal endothelial cell density after cataract extraction. Am J Ophthalmol 1979, 88: 93-6.

${ }^{149}$ Schultz RO, Glasser DB, Matsuda M, et al: Response of the corneal endothelium to cataract surgery. Arch Ophthalmol 1986, 104: 1164-9.

${ }^{150}$ Renard G, Pouliquen Y, Hirsch M: Regeneration of the human corneal endothelium. A SEM study. Albrecht Von Graefes Arch Klin Ophthalmol 1981, 215: 341-8.

${ }^{151}$ Laing RA, Neubauer L, Leibowitz HM, et al: Coalescence of endothelial cells in the traumatised cornea. II. Clinical observations., Arch Ophthalmol 1983, 101: 1712-15.

${ }^{152}$ Olbert D and Daus W: Multinucleated endothelial cells. Klin Monatsbl Augenheilkd 1984, 185: 462-4.

${ }^{153}$ Khodadoust AA and Green K. Physiological function of regenerating endothelium. Invest Ophthalmol Vis Sci 1976, 15: 96-101.

${ }^{154}$ Tsuru T, Araie M, Matsubara M, etal: Endothelial wound-healing of monkey cornea. Jpn J Ophthalmol 1984, 28: 105-25

${ }^{155}$ Minkowski JS, Bartels SP, Delori FC, et al: Corneal endothelial function and structure following cryo-injury in the rabbit. Invest Ophthalmol Vis Sci 1984, 25: 1416-25.

${ }^{156}$ Huang PT, Nelson LR, Bourne WM: The morphology 
and function of healing cat corneal endothelium. Invest Ophthalmol Vis Sci 1989, 30: 1794-801.

${ }^{157}$ Cogan DG and Kuwabara T: Growth and regenerative potential of Descemet's membrane. Trans Ophthalmol Soc UK 1971, 91: 875-94.

${ }^{158}$ Sugar J, Mitchelson J, Kraff M: Endothelial trauma and cell loss from intraocular lens insertion. Arch Ophthalmol 1978, 96: 449-50.

${ }^{159}$ Olson T and Erikson JS: Corneal thickness and endothelial damage after intraocular lens implantation. Acta Ophthalmol 1980, 58: 773-86.

${ }^{160}$ Rao GN, Acquavella JV, Goldberg SH, Bork SL: Pseudophakic bullous keratopathy. Ophthalmology 1984, 91: 1135-40.

${ }^{161}$ Drews RC: Intermittent touch syndrome. Arch Ophthalmol 1982, 100: 1440-1.

${ }^{162}$ Miller D and Doane MG: High speed photographic evaluation of intraocular lens movements. Am J Ophthalmol 1984, 97: 752-9.

${ }^{163}$ Yamaguchi T, Kanai A, Tanaka M, et al: Bullous keratopathy after anterior-posterior radial keratotomy for myopia and myopic astigmatism. Am J Ophthalmol 1982, 93: 600-6.

${ }^{164}$ Bourne WM and Kaufman HE: Endothelial damage associated with intraocular lenses. Am J Ophthalmol 1976, 81: $482-5$.

${ }^{165}$ Forstot SL, Blackwell WL, Jaffe NS, et al: The effect of intraocular lens implantation of the corneal endothelium. Trans Am Acad Ophthalmol and Otol 1977, 83: 195-203.

${ }^{166}$ Sugar A, Fetherolf EC, Lin LLK, et al: Endothelial cell loss from intraocular lens insertion. Ophthalmology 1978, 85: 394-9.

${ }^{167}$ Abbott RL and Forster RK: Clinical specular microscopy and intraocular surgery. Arch Ophthalmol 1979, 97: 1476-9.

${ }^{168}$ Kraff MC, Sanders Dr, Lieberman HL: Specular microscopy in cataract and intraocular lens patients. Arch Ophthalmol 1980, 98: 1782-4.

${ }^{169}$ Hirst LW, Snip RC, Stark WJ, et al: Quantitative corneal endothelial evaluation in intraocular lens implantation and cataract surgery. Am J Ophthalmol 1977, 84: 775-80.

${ }^{170}$ Bourne WM, Brubaker RF, O'Fallon WM: Use of air to decrease endothelial cell loss during intraocular lens implantation. Arch Ophthalmol 1979, 97: 1473-5.

${ }^{171}$ Hoffer KJ: Effects of extracapsular implant techniques on endothelial density. Am J Ophthalmol 1982, 100: 791-2.

${ }^{172}$ Polack FM and Sugar A: The phacoemulsification procedure II: corneal endothelial changes. Invest Ophthalmol Vis Sci 1976, 15: 458-69.

${ }^{173}$ Irvine AR, Kratz RP, O’Donnell JJ: Endothelial damage with phacoemulsification and intraocular lens implantation. Arch Opthalmol 1978, 96: 1023-6.

${ }^{174}$ Patel J, Apple, Hansen SO, et al: Protective effect of the anterior lens capsule during extracapsular cataract extraction. Ophthalmology 1989, 96: 598-602.

${ }^{175}$ Binkhorst CD, Nygaard P, Loones LH: Specular microscopy of the corneal endothelium and lens implant surgery. Am J Ophthalmol 1978, 85: 597-605.

${ }^{176}$ Taylor DM, Atlas BF, Romanchuk KG, et al: Pseudophakic bullous keratopathy. Ophthalmology 1983, 90: 19-24.

${ }^{177}$ Galin MS, Fetherolf E, Lin L, et al: Experimental cataract surgery-electron microscopy. Ophthalmology 1979, 86: 608-20.

${ }^{178}$ Sugar J, Mitchelson J, Kraff M: The effects of phacoemulsification on corneal endothelial cell density. Arch Ophthalmol 1978, 96: 446-8.

${ }^{179}$ Rao GN, Stevens RE, Harris JK, et al: Long-term changes in corneal endothelium following intraocular lens implantatioin. Ophthalmology 1981, 88: 386-97.
${ }^{180}$ Kraff MC, Sanders DR, Lieberman HL: Monitoring far continuing endothelial cell loss with cataract extraction and intraocular lens implantation. Ophthalmology 1982, 89: 30-4.

${ }^{181}$ Liesegang TJ, Bourne WM, Ilstrup DM: Short and longterm endothelial cell loss associated with cataract extraction and intraocular lens implantation. $A m$ J Ophthalmol 1984, 97: 32-9.

${ }^{182}$ Polack FM and Sugar A: The phacoemulsification pro cedure III. Corneal complications. Invest Ophthalmel Vis Sci 1977, 16: 9-46.

${ }^{183}$ Binder PS, Sternberg H, Wickman MG, et al: Corneal endothelial damage associated with phacoemulsification. Am J Ophthalmol 1976, 82: 48-54.

${ }^{184}$ Kaufman HE and Katz JI: Endothelial damage from intraocular lens insertion. Invest Ophthalmol Vis Sci 1976, 15: 996-1000.

${ }^{185}$ Kauf man HE, Katz J, Valenti J, et al: Corneal endothelial damage with intraocular lenses. Science 1977, 198: 525-7.

${ }^{186}$ Sherrard ES: Intraocular lens damage to the endothelium of the in vitro rabbit cornea. Trans Ophthalmol Soc UK 1983, 103: 565-76.

${ }^{187}$ Sugar J, Burnett J, Forstot SL: Scanning electron microscopy of intraocular lens and entothelial cell interaction. Am J Ophthalmol 1978, 86: 157-61.

${ }^{188}$ Apple DJ, Mamalis N, Loftfield K, et al: Complications of intraocular lenses. Surv Ophthalmol 1984, 29: 1-54.

${ }^{189}$ Thorburn DE and Levenson JE: Corneal endothelial damage from previously implanted intraocular lenses. Am Intraocular Implant Soc J 1980, 6: 236-8.

${ }^{190}$ Hammer ME and Burch TG: Viscous corneal protection by sodium hyaluronate, chondroitin sulfate, and methylcellulose. Invest Ophthalmol Vis Sci 1984, 25; 1329-32.

${ }^{191}$ Kirk S, Burde RM, Waltman SR: Minimising corneal endothelial damage due to intraoculular lens contact. Invest Ophthalmol Vis Sci 1977, 16: 1053-6.

${ }^{192}$ Cheng H, Law AB, McPherson K, et al: Longitudinal study of intraocular lens implants after intracapsular cataract extraction. Trans Ophthalmol Soc UK 1981, 101: $79-83$.

${ }^{193}$ Fechner PU and Fechner MU: Methylcellulose and lens implantation. Br J Ophthalmol 1983, 67: 259-63.

${ }^{194}$ MacRae SM, Edelhauser HF, Hyndiuk RA, et al: The effects of sodium hyaluronate, chondroitin sulphate and methylcellulose on the corneal endothelium and intraocular pressure. Am J Ophthalmol 1983, 95: 332-41.

${ }^{195}$ Packard RBS, Garner A, Arnott EJ: poly-HEMA as a material for intraocular lens implantation: a preliminary report. Br J Ophthalmol 1981, 65: 585-7.

${ }^{196}$ Percival P: Protective role of haelon during lens implantation. Trans Ophthalmol Soc UK 1981, 101: 77-8.

${ }^{197}$ Barrett G and Constable IJ: Corneal endothelial loss with new intraocular lens. Am J Ophthalmol 1984, 98: $157-65$.

${ }^{198}$ Farge EJ: Results of penetrating keratoplasty over a fouryear period. Ophthalmology 1978, 85: 650-3.

${ }^{199}$ Olson RJ, Waltman SR, Mattingley TP, Kaufman HE: Visual results after penetrating keratoplasty for aphakic bullous keratopathy and Fuchs's dystrophy. Am J Ophthalmol 1979, 88: 1000-4

${ }^{2(1)}$ Waring GO, Welch SN, Cavanagh HD, et al: Results of penetrating keratoplasty in 123 eyes with pseudophakic and aphakic corneal oedema. Ophthalmology 1983, 90: 25-33.

${ }^{201}$ Meyer R and Sugar A: Penetrating keratoplasty in pseudophakic bullous keratopathy. Am J Ophthalmol 1980, 90: 677-81.

${ }^{2012}$ Waltman SR: Penetrating keratoplasty for pseudophakic bullous keratopathy. Arch Ophthalmol 1981, 99: 415-16. 
${ }^{203}$ Schanzlin DJ, Robin JB, Gomez DS, et al: Results of penetrating keratoplasty for aphakic and pseudophakic bullous keratopathy. Am J Ophthalmol 1984, 98: 302-12.

${ }^{204}$ Kozarsky AM, Stopak S, Waring GO, et al: Results of penetrating keratoplasty for pseudophakic corneal oedema with retention of the intraocular lens. Ophthalmology 1984, 91: 1141-6.

${ }^{2015}$ Sugar A, Meyer RF, Heideman D, et al: Specular microscopic follow-up of corneal grafts for pseudophakic bullous keratopathy. Ophthalmology 1985, 92: 325-30.

${ }^{206}$ Waring GO, Stulting RD, Street D: Penetrating keratoplasty for pseudophakic corneal oedema with exchange of intraocular lens. Arch Ophthalmol 1987, 105: $58-62$.

${ }^{207}$ Leibowitz HM, Laing RA, Chang R, et al: Corneal oedema secondary to vitreocorneal contact. Arch Ophthalmol 1981, 99: 417-21.

${ }^{208}$ Gonnering R, Edelhauser HF, Van Horn DL, Durant W: The $\mathrm{pH}$ tolerance of rabbit and human corneal endothelium. Invest Ophthalmol Vis Sci 1979, 18: 373-90.

${ }^{209}$ Edelhauser HF, Hanneden AM, Pederson HJ, Van Horn DL: Osmotic tolerance of rabbit and human corneal endothelium. Arch Ophthalmol 1981, 99: 1282-7.

${ }^{210}$ Edelhauser HF, Hyndiuk RA, Zeeb A, Schultz RO: Corneal oedema and the intraocular use of epinephrine. Am J Ophthalmol 1982, 93: 327-33.

${ }^{211}$ Hull DS, Chemotti MT, Edelhauser HF, Van Horn DL, Hyndiuk RA: Effect of epinephrine on the corneal endothelium. Am J Ophthalmol 1975, 79: 245-50.

${ }^{212}$ Van Horn DL, Edelhauser HF, Prodanovich G, Eiferman $\mathrm{R}$, Pederson HJ: Effect of the ophthalmic preservative thimerosol on rabbit and human corneal endothelium. Invest Ophthalmol Vis Sci 1977, 16: 273-80.

${ }^{213}$ Weinreb RN, Wood I, Tomazzoli J, Alvarado J: Subconjunctival injections. Preservative-related changes in the corneal endothelium. Invest Ophthalmol Vis Sci 1986, 27: 525-31.

${ }^{214}$ Cohen KL, Van Horn DL, Edelhauser HF, et al: Effect of phenylephrine on normal and regenerated endothelial cells in cat cornea. Invest Ophthalmol Vis Sci 1979, 18: 242-9.

${ }^{215}$ Vaughn ED, Hull DS, Green K: Effect of intraocular miotics on corneal endothelium. Arch Ophthalmol 1978, 96: 1897-901

${ }^{216}$ Birnbaum DB, Hull DS, Green K, Frey NP: Effect of carbachol on corneal endothelium. Arch Ophthalmol 1987, 105: 253-5.

${ }^{217}$ Hull DS and Green K: Effect of urokinase on corneal endothelium. Arch Ophthalmol 1982, 98: 1285-6.

${ }^{218}$ Van Horn DL, Edelhauser HF, Aaberg TM, et al: In vivo effects of air and sulfa hexafluoride gas on rabbit corneal endothelium. Invest Ophthalmol Vis Sci 1972, 11: 1028-36.

${ }^{219}$ Leibowitz HM, Laing RA, Sandstrom M: Corneal endothelium: the effect of air in the anterior chamber. Arch Ophthalmol 1974, 92: 227-30.

${ }^{220}$ Olson RJ: Air and the corneal endothelium. Arch Ophthalmol 1980, 98: 1283-4.

${ }^{221}$ Eif erman RA and Wilkins EL: The effect of air on human corneal endothelium. Am J Ophthalmol 1981, 92: 328-31.

${ }^{222}$ Foulks GN, de Juan E, Hatchell DL, McAdoo T, Hardin $\mathrm{J}$ : The effect of perfluoropentane on the cornea in rabbits and cats. Arch Ophthalmol 1987, 105: 256-9.

${ }^{223}$ Friberg TR and Doran DL: The effect of vitreous and retinal surgery on central corneal cell density. Ophthalmology 1984, 91: 1166-9.

${ }^{224}$ Sternberg P, Hatchell DL, Foulks GN, Landers MB: The effect of silicone oil on the cornea. Arch Ophthalmol 1985, 103: 90-4

${ }^{225}$ Smith J and Whitted P: Corneal endothelial changes after argon laser iridotomy. Am J Ophthalmol 1982, 98: 153-6.

${ }^{226}$ Thoming C, Van Buskirk EM, Samples JR: The corneal endothelium after laser therapy for glaucoma. $\mathrm{Am} \mathrm{J}$ Ophthalmol 1987, 103: 518-22.

${ }^{227}$ Hirst LW, Robin AL, Sherman S, Green WR, D’Anna S, Dunkelberger G: Corneal endothelial changes after Argon laser iridotomy and panretinal photocoagulation. Am J Ophthalmol 1982, 93: 473-81.

${ }^{228}$ Meyer KT, Pettit TH, Straatsma BR: Corneal endothelial damage with Neodymium: YAG laser. Ophthalmology 1984, 91: 1022-8.

${ }^{229}$ Richardson TM, Brown SV, Thomas JV: Shock-wave effect on anterior segment structures following experimental Neodymium: YAG laser iridotomies. Ophthalmology 1985, 92: 1387-95.

${ }^{230}$ Kerr Muir MG and Sherrard ES: Damage to the corneal endothelium during Nd/YAG photodisruption. $\mathrm{Br} J$ Ophthalmol 1985, 69: 77-85.

${ }^{2.31}$ Marshall J, Trokel S, Rothery S, Krueger R: An ultrastructural study of corneal incisions induced by an excimer laser at $193 \mathrm{~nm}$. Ophthalmology 1985, 92: 749-58

${ }^{232}$ Ehlers N: Graft thickness after penetrating keratoplasty. Acta Ophthalmol 1974, 52: 893-903.

${ }^{233}$ Kimura C and Tanishima T: Thickness of the corneal graft after penetrating keratoplasty. J pn J Ophthalmol 1975 , 19: $348-53$

${ }^{234}$ Greiner JV, Lass JH, Glonek T: Metabolic status of fresh versus eye bank processed corneas. Arch Ophthalmol 1984, 102: 1676-7.

${ }^{235}$ Gottsch JD, Chen C-H, Aguayo JB, et al: Glycolytic activity in the human cornea monitored with nuclear magnetic resonance spectroscopy. Arch Ophthalmol 1986, 104: 886-9.

${ }^{236}$ Bourne WM and Kaufman HE: The endothelium of clear corneal transplants. Arch Ophthalmol 1976, 94: 1730-2.

${ }^{237}$ Bourne WM and O'Fallon WM: Endothelial cell loss during penetrating keratoplasty. Am J Ophthalmol 1978, 85: 760-6.

${ }^{238}$ Bourne WM: One year observation of transplanted human corneal endothelium. Ophthalmology 1980, 87: 673-9.

${ }^{239}$ Rao GN, Stevens RE, Mandelberg AI, et al: Morphologic variations in graft endothelium. Arch Ophthalmol 1980, 98: 1403-6.

${ }^{240}$ Culbertson WW, Abbott RL, Forster RK: Endothelial cell loss in penetrating keratoplasty. Ophthalmology 1982, 89: 600-4.

${ }^{241}$ Bahn CF, Meyer RF, MacCallum DK, et al: Penetrating keratoplasty in the cat. Ophthalmology 1982, 89: 687-99.

${ }^{242}$ Bourne WM: Morphologic and functional evaluation of the endothelium of transplanted human corneas. Trans Am Ophthalmol Soc 1983, 81: 403-50.

${ }^{243}$ Matsuda M, Suda T, Manabe R: Serial alteration of endothelial cell shape and pattern after intra-ocular surgery. Am J Ophthalmol 1984, 98: 313-19.

${ }^{244}$ Sato T: Studies of the endothelium of the corneal graft. Jpn J Ophthalmol 1978, 22: 114-26.

${ }^{245}$ Volker-Dieben HJ, Kok-Van Alphen CC, De Lange P: Corneal grafts for endothelial decompensation. Acta Ophthalmol 1984, 62: 436-44.

${ }^{246}$ Pollack FM, Smelser GK, Rose J: Long-term survival of isotopically labelled stromal and endothelial cells in corneal homografts. Am J Ophthalmol 1964, 57: 67-78.

${ }^{247}$ Basu PK, Miller I, Ormsby HL: Sex chromatin as a biological cell marker in the study of the fate of corneal transplants. Am J Ophthalmol 1960, 49: 513-15.

${ }^{248}$ Olson RJ and Levenson JE: Migration of donor endothelium in keratoplasty. Am J Ophthalmol 1977, 84: 711-14. 
${ }^{249}$ Bourne WM: In vivo survival of cryopreserved endothelial cells. Arch Ophthalmol 1974, 92: 146-8.

${ }^{250}$ Yang HJ, Sato T, Matsubara M, et al: Endothelial wound healing in penetrating corneal graft for experimental bullous keratopathy in rabbit. Jpn J Ophthalmol 1985, 29: $378-93$

${ }^{251}$ Bron AJ and Brown NAP: Endothelium of the corneal graft. Trans Ophthalmol Soc UK 1974, 94: 863-73.

${ }^{252}$ Ruusuvaara P: Endothelial cell densities in donor and recipient tissue after keratoplasty. Acta Ophthalmol 1980, 58: 267-77.

${ }^{253}$ Rao GN and Aquavella JV: Peripheral recipient endothelium following corneal transplantation. Ophthalmology 1981, 88: 50-5.

${ }^{254}$ Abbott RL, Fine M, Guillet E: Long-term changes in corneal endothelium following penetrating keratoplasty. Ophthalmology 1983, 90: 676-85.

${ }^{255}$ Khodadoust AA: The allograft rejection: the leading cause of late failure of corneal grafts. In Porter R, Knight J eds. Corneal Graft Failure. Ciba Foundation Symposium 15 (new series). Amsterdam: Elsevier Excerpta Medica North-Holland 1973: 151-67.

${ }^{256}$ Coster DJ: Factors affecting the outcome of corneal transplantation. Ann Royal Coll Surg Eng 1981, 63: 91-7.

${ }^{257}$ Volker-Dieben HJM: The effect of immunological and non-immunological factors on corneal graft survival. Dordrecht. D W Junk Publishers 1984: 1-174.

${ }^{258}$ Williams KA, White MA, Ash JK, Coster DJ: Leucocytes in the graft bed associated with corneal graft failure. Analysis by immunohistology and actuarial graft survival. Ophthalmology 1989, 96: 38-44.

${ }^{259}$ Williams KA, Coster DJ: The role of the limbus in corneal allograft rejection. Eye 1989, 3: 158-166.

${ }^{260}$ Hirst LW and Stark WJ: Clinical specular microscopy of corneal endothelial rejection. Arch Ophthalmol 1983; 101: 1387-91.

${ }^{261}$ Sundmacher R and Muller O: Endothelzellverluste nach keratoplastik. Klin Monatsbl Augenheilkd 1983, 182: 86-90.

${ }^{262}$ Pollack FM: The endothelium of failed corneal grafts. Am J Ophthalmol 1985, 79: 251-61.

${ }^{263}$ Whitsett CF and Stulting RD: The distribution of HLA antigens on human corneal tissue. Invest Ophthalmol Vis Sci 1984, 25: 519-24.

${ }^{264}$ Mayer DJ, Daar AS, Casey TA, Fabre JW: Localization of HLA-A, B, C and HLA-Dr antigens in the human cornea; practical significance for grafting technique and HLA typing. Transplant Proc 1983, 15: 126-9.

${ }^{265}$ Fujikawa LS, Colvin RB, Bahn AK, Fuller TC, Foster CS: Expression of HLA-A/B/C and Dr antigens on epithelial, stromal and endothelial cells on the human cornea. Cornea 1982, 1: 213-22.

${ }^{266}$ Vantrappen L, Geboes K, Missotten L, Maudgal PC, Desmet V: Lymphocytes and langerhans cells in the normal human cornea. Invest Ophthalmol Vis Sci 1985, 26: $220-5$.

${ }^{267}$ Williams KA, Ash JK, Coster DJ: Histocompatibility antigen and passenger cell content of normal and diseased human cornea. Transplantation 1985, 39: 265-9.

${ }^{268}$ Treseler PA, Foulkes GN, Sanfilippo F: The expression of HLA antigens by the human cornea. Am J Ophthalmol 1984, 98: 763-72.

${ }^{269}$ Treseler P and Sanfilippo F: The expression of major histocompatibility complex and leucocyte antigens by cells in the rat cornea. Transplantation 1986, 42: 248-52.

${ }^{270}$ Young E, Stark WJ, Prendergast RA: Immunology of corneal graft allograft rejection: HLA-Dr antigens on human corneal cells. Invest Ophthalmol Vis Sci 1985, 26: $571-4$.

${ }^{271}$ Donnelly JJ, Rockey JH, Prendergast RA: Induction of class II (Ia) alloantigen expression on corneal endothelium in vivo and in vitro. Invest Ophthalmol Vis Sci 1985, 26: $575-80$.

${ }^{272}$ Pepose JS, Gardner KM, Nestor MS, Foos RY, Pettit TH Detection of HLA class I and II antigens in rejected human corneal allografts. Ophthalmology 1985, 92: $1480-4$

${ }^{273}$ Dallman MJ and Mason DW: Induction of Ia antigens on murine epidermal cells during rejection of skin allografts. Transplantation 1983, 36: 222-34.

${ }^{274}$ Hall BM, Bishop GA, Duggin GG, Horvath JS, Phillips J, Tiller DJ: Increased expression of HLA-Dr antigens on renal tubular cells in renal transplants: relevance to the rejection response. Lancet 1984, 2: 247-51.

${ }^{275}$ Milton AD and Fabre JW: Massive induction of donortype class I and class II major histocompatability complex antigens in rejecting allografts in the rat. $J$ Exp Med 1985, 161: 98-112.

${ }^{276}$ McCulley JP, Maurice DM, Schwarz BD: Corneal endothelial transplantation. Ophthalmology 1980, 87: 194-201.

${ }^{277}$ Gospodarowicz D, Greenburg G, Alvarado J: Transplantation of cultured bovine endothelial cells to species with non-regenerative endothelium. The cat as an experimental model. Arch Ophthalmol 1979, 97: 2163-9.

${ }^{278}$ Newsome DA, Takasugi M, Kenyon KR, et al: Human corneal endothelial cells in vitro: morphology and histocompatibility (HL-A) antigens of pure cell populations. Invest Ophthalmol Vis Sci 1974, 13: 23-32.

${ }^{279}$ Bahn CF, Wind G, Hufnagel H, et al: Corneal endothelial cell replacement with autologous vascular endothelium in cats. Invest Ophthalmol Vis Sci (Supp) 1986, 27: 91.

${ }^{280}$ Schweigerer L, Ferrara N, Haaparanta T, Neufeld G, Gospodarowicz D: Basic fibroblastic growth factor. Exp Eye Res 1988, 46: 71-80.

${ }^{281}$ Squires EL and Weimar VL: Stimulation of repair of human corneal endothelium in organ culture by mesodermal growth factor. Arch Ophthalmol 1980, 98: 1462-6.

${ }^{282}$ Gospodarowicz D, Mescher AC, Birdwell CR: Stimulation of corneal endothelial cell proliferation in vitro by fibroblast and epidermal growth factor. Exp Eye Res 1977, 25: 75-89.

${ }^{283}$ Couch JM, Cullen P, Casey TA, Fabre JW: Mitotic activity of corneal endothelial cells in organ culture with recombinant human epidermal growth factor. Ophthalmology 1987, 94: 1-6.

${ }^{284}$ Bolande RP: The neurocristopathies. Hum Path 1974, 5: 409-29.

${ }^{285}$ Johnston MC: The neural crest in abnormalities of the face and brain. Birth Defects 1975, 11: 1-18.

${ }^{286}$ Bahn CF, Falls HF, Varley GA, et al: Classification of corneal endothelial disorders based on neural crest origin. Ophthalmology 1984, 91: 558-63.

${ }^{287}$ Beauchamp GR and Knepper PA: Role of the neural crest in anterior segment development and disease. $J$ Paed Ophthalmol Strab. 1984, 21: 209-14.

${ }^{288}$ Rodrigues MM, Stulting RD, Waring GO: Clinical, electron microscopic, and immunohistochemical study of the corneal endothelium and Descemet's membrane in the iridocorneal endothelial syndrome. Am J Ophthalmol 1986, 101: 16-27.

${ }^{289}$ Snip RC, Kenyon KR, Green WR: Retrocorneal fibrous membrane in the vitreous touch syndrome, . Am J Ophthalmol 1975, 79: 233-44.

${ }^{290}$ Kenyon KR, Van Horn DL, Edelhauser HF: Endothelial degeneration and posterior collagenous proliferation in aphakic bullous keratopathy. Am J Ophthalmol 1978, 85: 329-6.

${ }^{291}$ Waring GO: Posterior collagenous layer of the cornea Arch Ophthalmol 1982, 100: 122-34. 
${ }^{292}$ Michels RG, Kenyon KR, Maumenee AE: Retrocorneal fibrous membrane. Invest Ophthalmol vis Sci 1972, 11: 822-31.

${ }^{293}$ Silbert A M and Baum JL: Origin of the retrocorneal membrane in the rabbit. Arch Ophthalmol 1979, 97: 1141-3.

${ }^{294}$ Kay EP, Cheung C-C, Jester JV, et al: Type I collagen and fibronectin synthesis by retrocorneal fibrous membrane. Invest Ophthalmol Vis Sci 1982, 22: 200-12.

${ }^{295}$ Eagle RC, Font RL, Yanoff M, et al: Proliferative endotheliopathy with iris abnormality. Arch Ophthalmol 1979, 97: 2104-11.

${ }^{296}$ Kenyon KR: Mesenchymal dysgenesis in Peter's anomaly, sclerocorneal and congenital endothelial dystrophy. Exp Eye Res 1975, 21: 125-42.

${ }^{297}$ Kupfer C and Kaiser-Kupfer MI: Observations of the development of the anterior chamber angle with reference to the pathogenesis of congenital glaucoma. $\mathrm{Am} \mathrm{J}$ Ophthalmol 1979, 88: 424-6.

${ }^{298}$ Dorp DB Van, Delleman JW, Loewer-Sieger DH: Oculocutaneous albinism and anterior chamber cleavage malformation. Clin Genet 1984, 26: 440-4.

${ }^{299}$ Hittner HM, Kretzer FL, Antoszyk JH, et al: Variable expressivity of autosomal dominant anterior segment mesenchymnal dysgenesis in six generations. Am J Ophthalmol 1982, 93: 57-70.

${ }^{300}$ Reese $\mathrm{AB}$ and Ellesworth RM: The anterior chamber cleavage syndrome. Arch Ophthalmol 1966, 75: 307-18.

${ }^{301}$ Townsend WM: Congenital corneal leukomas I. Am J Ophthalmol 1974, 77: 80-6.

${ }^{302}$ Townsend WM: Congenital corneal leukomas II. Am J Ophthalmol 1974, 77: 192-206.

${ }^{303}$ Waring GO: Anterior chamber cleavage syndrome. Surv Ophthalmol 1975, 20: 3-27.

${ }^{304}$ Shields MB, Buckley E, Klintworth GK, et al: AxenfeldReiger syndrome. A spectrum of developmental disorders. Surv Ophthalmol 1985, 29: 387-409.

${ }^{305}$ Nakanishi I and Brown SI: The histopathology and ultrastructure of congenital, central corneal opacity (Peter's anomaly). Am J Ophthalmol 1971, 72: 801-12.

${ }^{306}$ Kupfer C, Kuwabara T, Stark WJ: The histopathology of Peter's anomaly. Am J Ophthalmol 1975, 80: 653-60.

${ }^{307}$ Stone DL, Kenyon KR, Green WR, et al: Congenital central corneal leukoma (Peter's anomaly). Am J Ophthalmol 1976, 81: 173-93.

${ }^{308}$ Johnson BL and Brown SI: Congenital epithelialisation of the posterior cornea. Am J Ophthalmol 1976, 82: 83-9.

${ }^{309}$ Kanai A, Wood TC, Pollack FM, et al: The fine structure of sclerocornea. Invest Ophthalmol Vis Sci 1971, 10: 687-94.

${ }^{310}$ Kenyon KR and Maumenee AE: Further studies of congenital hereditary endothelial dystrophy of the cornea. Am J Ophthalmol 1973, 76: 419-39.

${ }^{311}$ Zinn KM: Changes in corneal ultrastructure resulting from early lens removal in the developing chick embryo. Invest Ophthalmol Vis Sci 1970, 9: 165-82.

${ }^{312}$ Maumenee AE: Congenital hereditary corneal dystrophy. Am J Ophthalmol 1960, 50: 1114-24.

${ }^{313}$ Antine B: Histology of congenital hereditary corneal dystrophy. Am J Ophthalmol 1970, 69: 964-9.

${ }^{314}$ Judisch GF and Maumenee IH: Clinical differentiation of recessive congenital hereditary endothelial dystrophy and dominant hereditary endothelial dystrophy. $\mathrm{Am} \mathrm{J}$ Ophthalmol 1978, 85: 606-12.

${ }^{315}$ Pearce WG, Tripathi RC, Morgan G: Congenital endothelial dystrophy. Br J Ophthalmol 1969, 53: 577-91.

${ }^{316}$ Kenyon KR and Maumenee AE: Further studies of congenital hereditary endothelial dystrophy of the cornea. Am J Ophthalmol 1973, 76: 419-39.

${ }^{317}$ Stainer GA, Akers PH, Binder PS, et al: Correlative microscopy and tissue culture of congenital hereditary endothelial dystrophy. Am J Ophthalmol 1982, 93: 456-65.

${ }^{318}$ Waring GO, Rodrigues MM, Laibson PR. Corneal dystrophies. II. Endothelial dystrophies. Surv Ophthalmol 1978, 23: 147-68.

${ }^{319}$ Chan CC, Green WR, Barraquer J, et al: Similarities between posterior polymorphous and congenital endothelial dystrophies. Cornea 1982, 1: 155-72.

${ }^{320}$ Sumers KD, Cavanagh HD, Waring GO: Pediatric keratoplasty. Ophthalmology 1981, 88: 71-6.

${ }^{321}$ Kirkness CM, McCartney A, Rice NSC, Garner A, Steele ADM: Congenital hereditary corneal oedema of Maumenee: Its clinical features, management and pathology. Br J Ophthalmol 1987, 71: 130-44.

${ }^{322}$ Strachen IM and MacLean H: Posterior polymorphous dystrophy of the cornea. Br J Ophthalmol 1968, 52: 270-2

${ }^{323}$ Cibis GW, Krachmer JA, Phelps CD, et al: The clinica spectrum of posterior polymorphous dystrophy. Arch Ophthalmol 1977, 95: 1529-37.

${ }^{324}$ Cibis GW and Tripathi RC: The differential diagnosis of Descemet's tears (Haab's striae) and posterior polymorphous dystrophy (PPD) bands. A clinicopathological study. Ophthalmology 1982, 89: 614-20.

${ }^{325}$ Hirst LW and Waring GO: Clinical specular microscopy of posterior polymorphous endothelial dystrophy. $\mathrm{Am} \mathrm{J}$ Ophthalmol 1983, 95: 143-55.

${ }^{326}$ Pardos GJ, Krachmer JH, Mannis MJ: Posterior corneal vesicles. Arch Ophthalmol 1981, 99: 1573-77.

${ }^{327}$ Grayson M: The nature of hereditary deep polymorphous dystrophy of the cornea: its association with iris and anterior chamber dysgenesis. Trans Am Ophthalmol Soc 1974, 72: 516-59.

${ }^{328}$ Rodrigues MM, Phelps CD, Krachmer JH, et al: Glaucoma due to endothelialisation of the anterior chamber angle. Arch Ophthalmol 1980, 98: 688-96.

${ }^{329}$ Bourgeois J, Shields MB, Thresher R: Open-angle glaucoma associated with posterior polymorphous dystrophy. Ophthalmology 1984, 91: 420-3.

${ }^{330}$ Boruchoff SA and Kuwabara T: Electron microscoply of posterior polymorphous degeneration. Am J Ophthalmol 1971, 72: 879-87.

${ }^{331}$ Richardson WP and Hettinger ME: Endothelial and epithelial-like cell formation in a case of posterior polymorphous dystrophy. Arch Ophthalmol 1985, 103: $1520-24$.

${ }^{332}$ Rodrigues MM, Newsome DA, Krachmer JH, et al: Posterior polymorphous dystrophy of the cornea: cell culture studies. Exp Eye Res 1981, 33: 535-44.

${ }^{333}$ Rodrigues MM, Sun T-T, Krachmer J, et al: Epithelialisation of the corneal endothelium in posterior polymorphous dystrophy. Invest Ophthalmol Vis Sci 1980 19: $832-5$.

${ }^{334}$ Shamsuddin AKM, Nirankari VS, Purneil DM, et al: Is the corneal posterior cell layer truly endothelial. $\mathrm{Oph}$ thalmology 1986, 93: 1298-303.

${ }^{335}$ Tripathi RC, Casey TA, Wise G: Hereditary posterior polymorphous dystrophy: an ultrastructural and clinical report. Trans Ophthalmol Soc UK 1974, 94: 211-25.

${ }^{336}$ Morgan G and Patterson A: Pathology of posterior polymorphous degeneration of the cornea. Br JOphthalmol 1967, 51: 433-7.

${ }^{337}$ Hogan MJ and Bietti G: Hereditary deep dystrophy of the cornea (polymorphous). Am J Ophthalmol 1969, 68: $777-88$.

${ }^{338}$ Hanna C, FraunfelderFT, McNair JR: An ultrastructural study of posterior polymorphous dystrophy of the cornea. Ann Ophthalmol 1977, 9: 1371-8.

${ }^{339}$ Johnson BL and Brown SI: Posterior polymorphous dystrophy: a light and electron microscopic study, $\mathrm{Br} J$ Ophthalmol 1978, 62: 89-96.

${ }^{340}$ Henriquez AS, Kenyon KR, Dohlman CH, et al: Mor- 
phologic characteristics of posterior polymorphous dystrophy. A study of nine corneas and review of the literature. Surv Ophthalmol 1984, 29: 139-47.

${ }^{341}$ Polack FM, Bourne WM, Forstot SL, et al: Scanning electron microscopy of posterior polymorphous corneal dystrophy. Am J Ophthalmol 1980, 89: 575-84.

${ }^{342}$ Laing RA, Leibowitz HM, Oak SS, et al: Endothelial mosaic in Fuchs' dystrophy. Arch Ophthalmol 1981, 99: 80-3.

${ }^{343}$ Waring GO, Font RL, Rodrigues MM, et al: Alterations of Descemet's membrane in interstitial keratitis. $\mathrm{Am} \mathrm{J}$ Ophthalmol 1976, 81: 773-85.

${ }^{344}$ Krachmer JH, Purcell JJ, Young CW, et al: Corneal endothelial dystrophy. Arch Ophthalmol 1978, 96: 2036-9.

${ }^{345}$ Lorenzetti DWC, Uotila MH, Parikh N, et al: Central cornea guttata: incidence in the geberal population. Am J Ophthalmol 1967, 64: 1155-8.

${ }^{346}$ Cross HE, Maumenee AE, Cantolino SJ: Inheritance of Fuchs' endothelial dystrophy. Arch Ophthalmol 1971, 85: $268-72$

${ }^{347}$ Rosenblum P, Stark WJ, Maumenee IH, et al: Hereditary Fuchs' dystrophy. Am J Ophthalmol 1980, 90: 455-62.

${ }^{348}$ Renard G and Pouliquen Y: Aspects au microscope à balayage de l'endothélium cornéen dans une dystrophie endothéliale de Fuchs (cornea guttata). Arch Ophthalmol (Paris) 1974, 34: 413-30.

${ }^{349}$ Bourne WM, Johnson DH, Campbell RJ: The ultrastructure of Descemet's membrane. III. Fuchs' dystrophy. Arch Ophthalmol 1982, 100: 1952-5.

${ }^{350}$ Iwamoto T and DeVoe AG: Electron microscopic studies on Fuchs' combined dystrophy. I. Posterior portion of the cornea. Invest Ophthalmol Vis Sci 1971, 10: 9-28.

${ }^{351}$ Polack FM: The posterior corneal surface in Fuchs' dystrophy. Invest Ophthalmol Vis Sci 1974, 13: 913-22.

${ }^{352}$ Hogan MJ, Wood I, Fine M: Fuchs' endothelial dystrophy of the cornea. Am J Ophthalmol 1974, 78: 363-83.

${ }^{353}$ Burns RR, Bourne WM, Brubaker RE: Endothelial function in patients with corneal guttata. Invest Ophthalmol Vis Sci 1981, 20: 77-85.

${ }^{354}$ Geroski DH, Matsuda M, Yee RW, et al: Pump function of the human corneal endothelium. Ophthalmology 1985, 92: 759-63.

${ }^{355}$ Wilson SE, Bourne WM, Brubaker RF: Effect of dexamethasone on corneal endothelial function in Fuch's endothelial dystrophy. Invest Ophthalmol Vis Sci 1988, 29: $357-61$

${ }^{356}$ Olsen T, Ehlers N, Favini E: Long-term results of corneal grafting on Fuchs' endothelial dystrophy. Acta Ophthalmol 1984, 62: 445-52.

${ }^{357}$ Stocker FW and Irish A: Fate of successful corneal grafts in Fuchs' endothelial dystrophy. Am J Ophthalmol 1969, 68: 820-4.

${ }^{358}$ Fine $\mathrm{M}$ and West CE: Late results of keratoplasty for Fuchs' dystrophy. Am J Ophthalmol 1971, 72: 109-14.

${ }^{359}$ Olson T, Ehlers N, Favini E: Long-term results of corneal grafting in Fuchs' endothelial dystrophy. Acta Ophthalmol 1984, 62: 445-52.

${ }^{360}$ Roth SI, Stock EL, Jutacha R: Endothelial viral inclusions in Fuchs' corneal dystrophy. Hum Pathol 1987, 18: 338-41.

${ }^{361}$ Bramsen T and Ehlers N: Bullous keratopathy (Fuchs' Endothelial dystrophy) treated systemically with 4-trans-amino-cyclohexano-carboxylic acid. Acta Ophthalmol 1977, 55: 665-73.

${ }^{362}$ Hull DS, Green K, Boyer JG: Tranexamic acid and corneal deturgescence. Acta Ophthalmol 1979, 57: 252-7.

${ }^{363}$ Shields MB, Campbell DG, Simmons RJ: The essential iris atrophies. Am J Ophthalmol 1978, 85: 749-59.

${ }^{364}$ Eagle RC, Font RL, Yanoff M, Fine BS: Proliferative endotheliopathy with iris abnormality. Arch Ophthalmol 1979, 97: 2104-11.
${ }^{365}$ Chandler PA: Atrophy of the stroma of the iris, endo thelial dystrophy, corneal oedema and glaucoma. $\mathrm{Am}$ J Ophthalmol 1956, 41: 607-15.

${ }^{366}$ Hetherington J: The spectrum of Chandler's syndrome. Ophthalmology 1978, 85: 240-4.

${ }^{367}$ Lichter PR: The spectrum of Chandler's syndrome: an of ten overlooked cause of unilateral glaucoma. $O p h$. thalmology 1978, 85: 245-51.

${ }^{368}$ Cogan DG and Reese AB: A syndrome of iris nodules, ectopic Descemet's membrane and unilateral glaucoma. Doc Ophthalmol 1969, 26: 424-33. Essential iris atrophy.

${ }^{369}$ Shields MB, Campbell DG, Simmons RJ, et al: Iris nodules in essential iris atrophy. Arch Ophthalmol 1976, 94: 406-10.

${ }^{370}$ Duke-Elder S and Perkins ES: Diseases of the uveal tract. In System of Ophthalmology St Louis: CV Mosby 1966 Vol 9, 686-94.

${ }^{371}$ Blum JV, Allen JH, Holland MG: Familial bilateral essential iris atrophy (group 2). Trans Am Acad Oph thalmol Otolaryngol 1962, 66: 493-500.

${ }^{372}$ Kaiser-Kupfer M, Kuwabara T, Kupfer C: Progressive bilateral essential iris atrophy. Am J Ophthalmol 1977, 83: $340-6$.

${ }^{373}$ Hirst LW, Quigley HA, Stark WJ: Specular microscopy of iridocorneal endothelial syndrome. Am J Ophthalmol 1980, 89: 11-21

${ }^{374}$ Kupfer C, Kaiser-Kupfer M, Datiles M, et al: The contralateral eye in the irido corneal endothelial (ICE) syndrome. Ophthalmology 1983, 90: 1343-50.

${ }^{375}$ Bourne WM: Partial corneal involvement in the iridocorneal endothelial syndrome. Am J Ophthalmol 1982, 94: $774-81$

${ }^{376}$ Neubauer L, Lund O, Leibowitz HM: Specular microscopic appearance of the endothelium in iridocorneal endothelial syndrome. Arch Ophthalmol 1983, 101: 916-8.

${ }^{377}$ Richardson TM: Corneal decompensation in Chandler's syndrome. A scanning and transmission electron microscopic study. Arch Ophthalmol 1979, 97: 2112-19.

${ }^{378}$ Patel A, Kenyon KR, Hirst LW, et al: Clinicopathologic features of Chandler's syndrome. Surv Ophthalmol 1983, 27: 327-44.

${ }^{37 y}$ Alvarado JA, Murphy CG, Maglio M, et al: Pathogenesis of Chandler's syndrome, essential iris atrophy and the Cogan-Reese syndrome I. Invest Ophthalmol Vis Sci 1986, 27: 853-72.

: Alvarado JA, Murphy CG, Juster RP, et al: Pathogenesis of Chandler's syndrome, essential iris atrophy and the Cogan-Reese syndrome II. Invest Ophthalmol Vis Sci 1986, 27: 873-82.

${ }^{381}$ Wolter JR and Makley TA: Cogan-Reese syndrome: formation of a glass membrane on an iris nevus clinically simulating tumour growth. J Paed Ophthalmol 1972, 9: $102-5$.

${ }^{382}$ Eagle RC, Font RL, Yanoff M, et al: The iris naevus (Cogan-Reese) syndrome: Light and electron microscopic observations. Br J Ophthalmol 1980, 64: 446-52.

${ }^{383}$ Hirst LW, Green WR, Luckenbach M, et al: Epithelial characteristics of the endothelium in Chandler's syndrome. Invest Ophthalmol Vis Sci 1983, 24: 603-11.

${ }^{384}$ Portis J M, Stamper RL, Spencer WH: The corneal endothelium and Descemet's membrane in the iridocorneal endothelial syndrome. Trans Am Ophthalmol Soc 1985, 83: 316-31.

${ }^{365}$ Scheie HG and Yanoff M: Iris nevus (Cogan-Reese) syndrome. A cause of unilateral glaucoma. Arch Ophthalmol 1975, 93: 963-70.

${ }^{386}$ Miron MS: Le glaucome par atrophie essentielle progressive de l'iris. Ophthalmologica 1961, 142: 301-29.

${ }^{387}$ Pau H, Graeber W, Holtermann W: Die fortschreitend atropie irisstromas mit lochbildung und proliferation 
des hornhautendothels. Klin Monatsbl Augenheilkd 1962, 141: 568-82.

${ }^{388} \mathrm{Jampol}$ LM, Rosser MJ, Sears ML: Unusual aspects of progressive essential iris atrophy. Am J Ophthalmol 1974, 77: 353-7.

${ }^{389}$ Heath P: Essential atrophy of the iris. Am J Ophthalmol 1954, 37: 219-34.

${ }^{390}$ Campbell DG, Shields MB, Smith TR: The corneal endothelium and the spectrum of essential iris atrophy. $A m \mathrm{~J}$ Ophthalmol 1978, 86: 317-24.

${ }^{391}$ Kidd M, Hetherington J, Magee S: Surgical results in iridocorneal endothelial syndrome. Arch Ophthalmol 1988, 106: 199-201.

${ }^{392}$ Buxton JN and Lash RS: Results of penetrating keratoplasty in the iridocorneal endothelial syndrome. $\mathrm{Am}$ J Ophthalmol 1984, 98: 297-301.

${ }^{393}$ Crawford GJ, Stulting RD, Cavanagh HD, et al: Penetrating keratoplasty in the management of iridocorneal endothelial syndrome. Cornea 1989, 8: 34-40.

${ }^{394}$ Cameron JD, Flaxman BA, Yanoff M: In vitro studies of corneal wound healing: epithelial-endothelial interactions. Invest Ophthalmol Vis Sci 1974, 13: 575-9.

${ }^{395}$ Yanoff $\mathbf{M}$ and Cameron JD: Human cornea organ cultures. Invest Ophthalmol Vis Sci 1977, 16: 269-73.

${ }^{396}$ Terry TL, Chisholm JF, Schonberg AL: Studies on surface-epithelial invasion of the anterior segment of the eye. Am J Ophthalmol 1939, 22: 1083-8.

${ }^{397}$ Jensen P, Minckler DS, Chandler JW: Epithelial ingrowth. Arch Ophthalmol 1977, 95: 837-42.

${ }^{398}$ Laing RA, Sandstrom MM, Leibowitz HM, et al: Epithelialisation of the anterior chamber. Arch Ophthalmol 1979, 97: 1870-4.

${ }^{399}$ Zavala EY and Binder PS: The pathologic findings of epithelial ingrowth. Arch Ophthalmol 1980, 98: 2007-14.

${ }^{400}$ Burris TE, Nordquist RE, Rowsey JJ: Model of epithelial downgrowth. Cornea 1986, 4: 244-52.

${ }^{401}$ Kaufer G, Fine BS, Green WR, et al: Retrocorneal pigmentation. Am J Ophthalmol 1967, 64: 567-86.

${ }^{402}$ Snip RC, Green WR, Kreutzer EW, et al: Posterior corneal pigmentation and fibrous proliferation by iris melanocytes. Arch Ophthalmol 1981, 99: 1232-8.

${ }^{403}$ Wolter JR: Replacement of the corneal endothelium by melanocytes. Albrecht von Graefes Arch Klin Exp Ophthalmol 1981, 217: 247-53.

${ }^{404}$ Kampik A, Patrinely JR, Green WR: Morphologic and clinical features of retrocorneal melanin pigmentation and pigmented pupillary membranes: review of 225 cases. Surv Ophthalmol 1982, 27: 161-80.

${ }^{405}$ Laing RA, Sandstrom MM, Berrospi AR, et al: The human corneal endothelium in keratoconus. Arch Ophthalmol 1979, 97: 1867-9.

${ }^{406}$ Slingsby JG and Forstot SL: Effect of blunt trauma on the corneal endothelium. Arch Ophthalmol 1981, 99: 1041-3

${ }^{407}$ Roper-Hall MJ, Wilson RS, Thompson SM: Changes in endothelial cell density following accidental trauma. $\mathrm{Br}$ J Ophthalmol 1982, 66: 518-19.

${ }^{408}$ Maloney WF, Colvard DM, Bourne WM, et al: Specular microscopy of traumatic posterior annular keratopathy. Arch Ophthalmol 1979, 97: 1647-50.

${ }^{409}$ Wolff SM and Zimmerman LE: Endothelial overgrowth following traumatic angle recession. Am J Ophthalmol 1962, 54: 547-63.

${ }^{410}$ Wolter JR and Fechner PU: Glass membranes on the anterior iris surface. Am J Ophthalmol 1962, 53: 235-43.

${ }^{411}$ Calosi NJ and Yanoff M: Reactive corneal endothelialisation. Am J Ophthalmol 1977, 83: 219-24.

${ }^{412}$ Gartner S, Taffet S, Friedman AH: The association of rubeosis iridis with endothelialisation of the anterior chamber. Br J Ophthalmol 1977, 61: 267-71.

${ }^{413}$ Khodadoust AA and Hirst LW: Diurnal variation in cor- neal endothelial morphology. Ophthalmology 1984, 91 : 1125-8.

${ }^{414}$ Zantos SG and Holden BA: Transient endothelia changes soon after wearing soft contact lenses. $A m$ Optom Physiol Opt 1977, 54: 851-8.

${ }^{415}$ Bergmanson JPG and Chu LW-F: Corneal response to rigid contact lens wear. $\mathrm{Br} J$ Ophthalmol 1982, 66: 667-75.

${ }^{416}$ Klyce SD: Stromal lactate accumulation can account for corneal oedema osmotically following epithelial hypoxia in the rabbit. J Physiol 1981, 321: 49-64.

${ }^{417}$ Bonanno JA and Polse KA: Corneal acidosis during contact lens wear: Effects of hypoxia and $\mathrm{CO}_{2}$. Invest Oph thalmol Vis Sci 1987, 28: 1514-20.

${ }^{418}$ Schoessler JP: Corneal endothelial polymegathism associated with extended wear lenses. Intern $C L$ Clinic 1983, 10: 9-15.

${ }^{419}$ Hirst LW, Auer C, Cohn J, et al: Specular microscopy of hard contact lens wearers. Ophthalmology 1984, 91: $1147-53$.

${ }^{420}$ Stocker EG and Schoessler JP: Corneal endothelial polmegathism induced by PMMA contact lens wear. Invest Ophthalmol Vis Sci 1985, 26: 857-63.

${ }^{421}$ Holden BA, Sweeney DA, Vannas A, et al: Effects of long-term extended contact wear on the human cornea. Invest Ophthalmol Vis Sci 1986, 26: 1489-501.

${ }^{422}$ Macrae SM, Matsuda M, Shellans S, et al: The effect of hard and soft contact lenses on the corneal endothelium. Am J Ophthalmol 1986, 102: 50-7.

${ }^{423}$ Carlson KH, Bourne WM, Brubaker RF: Effect of longterm contact lens wear on corneal endothelial cell morphology and function. Invest Ophthalmol Vis Sci 1988, 29: $185-93$

${ }^{424}$ Matsuda M, Macrae SM, Inaba M, et al: The effect of hard contact lens wear on the keratoconic corneal endothelium after penetrating keratoplasty. Am J ophthalmol 1989, 107: 246-51

${ }^{425}$ Nielsen NV, Eriksen JS, Olsen T: Corneal edema as a result of ischaemic endothelial damage: a case report. Ann Ophthalmol 1982, 14: 276-8.

${ }^{426}$ Pfister RR, Friend J, Dohlman CH: Anterior segment necrosis in rabbits. Arch Ophthalmol 1971, 86: 301-7.

${ }^{427}$ Ytteborg J: Corneal oedema and intraocular pressure II. Arch Ophthalmol 1965, 74: 477-84.

${ }^{428}$ Ehlers N: On corneal thickness and intraocular pressure II. Acta Ophthalmol 1970, 48: 1107-12.

${ }^{429}$ Olson RJ and Kaufman HE: Intraocular pressure and corneal thickness after penetrating keratoplasty. $A m \mathrm{~J}$ Ophthalmol 1978, 86: 97-100.

${ }^{430}$ Svedbergh B: Effects of artificial intraocular pressure elevation on the corneal endothelium in the velvet monkey. Acta Ophthalmol 1975, 53: 839-55.

${ }^{431}$ Melamed S, Ben-Sira I, Ben-Shaul Y: Corneal endothelial changes under induced intraocular pressure elevation. Br J Ophthalmol 1980, 64: 164-9.

${ }^{432}$ Bigar $\mathrm{F}$ and Witmer R: Corneal endothelial changes in primary acute angle-closure glaucoma. Ophthalmology 1982, 89: 596-9.

${ }^{433}$ Olsen T: The endothelial cell damage in acute glaucoma. Acta Ophthalmol 1980, 58: 257-66.

${ }^{434}$ Murrell WJ, Shihab Z, Lamberts DW, et al: The corneal endothelium and central corneal thickness in pigmen tary dispersion syndrome. Arch Ophthalmol 1986, 104: 845-6.

${ }^{435}$ Vannas A, Setala K, Ruusuvaara P: Endothelial cells in capsular glaucoma. Acta Ophthalmol 1977, 55: 951-58.

${ }^{436}$ Korey M, Gieser D, Kass MA, et al: Central corneal endothelial cell density and central corneal thickness in ocular hypertension and primary open-angle glaucoma. Am J Ophthalmol 1982, 94: 610-16.

${ }^{437}$ Miyake K, Matsuda M, Inaba M: Corneal endothelia changes in pseudexfoliative syndrome. Am J Ophthalmol 1989, 108: 49-52.

${ }^{438}$ Reijo A, Antti V, Jukka M: Endothelial cellloss in herpes zoster keratouveitis. Br J Ophthalmol 1983, 67: 751-4.

${ }^{439}$ Ringvold A, Davanger M, Olsen EG: Changes of the cor- 
neal endothelium after ultraviolet radiation. Acta Ophthalmol 1982, 60: 41-53.

${ }^{440}$ Riley MV, Susan S, Peters MI, Schwartz CA. The effect of UV-B radiation on the corneal endothelium. Curr Eye Res 1987, 6: 1021-33.

${ }^{441}$ Zantos SG and Holden BA: Guttate endothelial changes with anterior eye inflammation. Br J Ophthalmol 1981, 65: 101-3.

${ }^{442}$ Krachmer JH, Schnitzer JI, Fratkin J: Cornea pseudoguttata. Arch Ophthalmol 1981, 99: 1377-81.

${ }^{443}$ Setala K: Corneal endothelial cell density in iridocyclitis. Acta Ophthalmol 1979, 57: 277-86.

${ }^{444}$ Inomata $\mathrm{H}$ and Smelser GK: Fine structural alterations of corneal endothelium during experimental uveitis. Invest Ophthalmol Vis Sci 1970, 9: 272-85.

${ }^{445}$ Harlan JM, Killen PD, Harker LA, et al: Neutrophilmediated endothelial injury in vitro. J Clin Invest 1981, 68: $1394-403$.

${ }^{446}$ Arya DV, Mannagh J, Irvine Ar, et al: Effect of lysosomes on corneal endothelium; an in vivo study. Invest Ophthalmol vis Sci 1972, 11: 655-61.

${ }^{447}$ Vannas A, Ahonen R, Makitie J: Corneal endothelium in herpetic keratouveitis. Arch Ophthalmol 1983, 101: 913-15.
${ }^{448}$ Khodadoust A A and Attarzadeh A: Presumed autoimmune corneal endotheliopathy. Am J Ophthalmol 1982, 93: 718-22.

${ }^{449}$ Ohashi Y, Kinoshita S, Mano T, et al: Idiopathic corneal endotheliopathy. Arch Ophthalmol 1985, 103: 1666-8.

${ }^{450}$ Snip RC, Kenyon KR, Green WR: Macular corneal dystrophy. Invest Ophthalmol Vis Sci 1973, 12: 88-97.

${ }^{451}$ Pardos GJ and Krachmer JH: Comparison of endothelial cell density in diabetes and a control population. $\mathrm{Am} \mathrm{J}$ Ophthalmol 1980, 90: 172-4.

${ }^{452}$ Schultz RO, Matsuda M, Yee RW, et al: Corneal endothelial changes in type I and type II diabetes mellitus. Am J Ophthalmol 1984, 98: 401-10.

${ }^{453}$ Lass JH, Spurney RV, Dutt RM, et al: A morphologic and fluorophotometric analysis of the corneal endothelium in type I diabetes mellitus and cystic fibrosis. Am J Ophthalmol 1985, 100: 783-8.

${ }^{454}$ Engerman RL and Colquhoun PJ: Epithelial and mesothelial basement membrane in diabetic patients and dogs. Diabetologia 1982, 23: 521-4.

${ }^{455}$ Shetlar DJ, Bourne WM, Campbell J: Morphologic evaluation of Desceniet's membrane and corneal endothelium in diabetes mellitus. Ophthalmology 1989, 96: 247-50. 